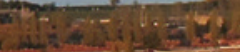

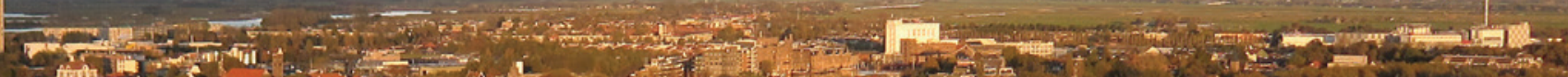

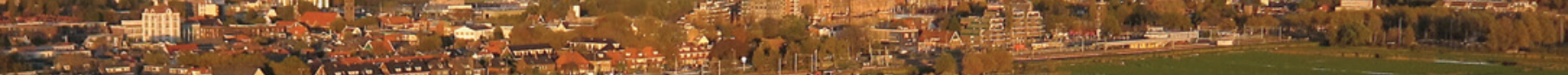

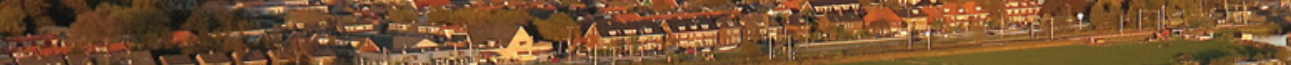

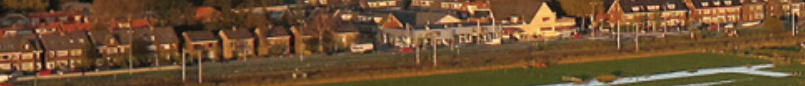
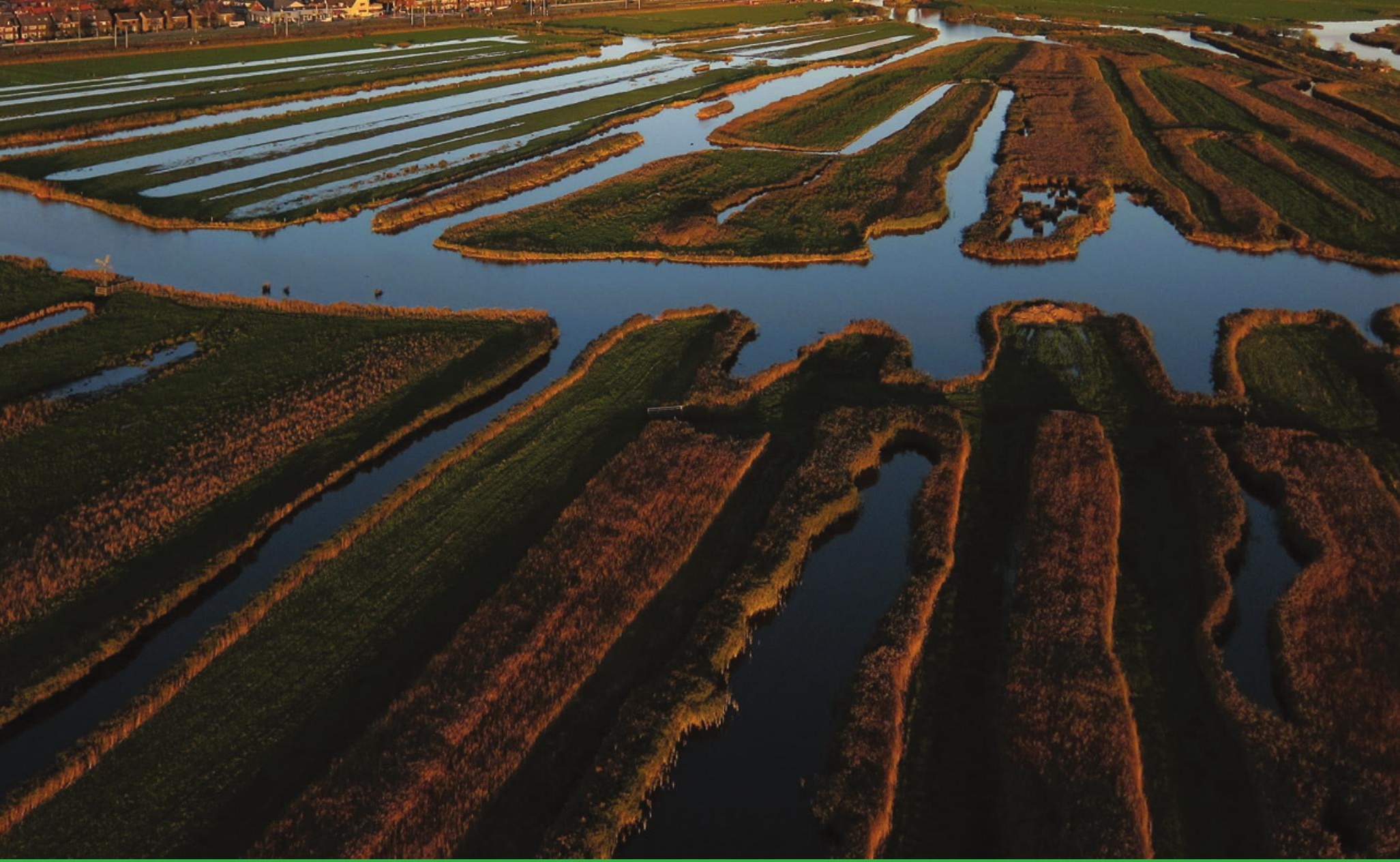

\title{
Meetnet Biodiversiteit Zaanstad
}

Fabrice Ottburg, Dennis Lammertsma en Ruut Wegman 



\section{Meetnet Biodiversiteit Zaanstad}

Fabrice Ottburg, Dennis Lammertsma en Ruut Wegman

Dit onderzoek is uitgevoerd door Wageningen Environmental Research in opdracht van Gemeente Zaanstad.

Wageningen Environmental Research

Wageningen, februari 2018

Rapport 2866

ISSN 1566-7197 
Ottburg, F.G.W.A., D.R. Lammertsma en R.M.A. Wegman, 2018. Meetnet Biodiversiteit Zaanstad. Wageningen, Wageningen Environmental Research, Rapport 2866. 58 blz.; 7 fig.; 13 tab.; 21 ref.

Een motie van Groen Links binnen de gemeente Zaanstad, waarin het 'Monitoren van Biodiversiteit' als speerpunt staat gemeld, is de aanleiding voor de gemeente Zaanstad om te laten onderzoeken hoe biodiversiteit binnen de gemeentegrenzen kan worden gemeten en gevolgd.

Hiervoor heeft gemeente Zaanstad Wageningen Environmental Research gevraagd voor het opzetten van een meetinstrument voor de biodiversiteit in de gemeente Zaanstad ofwel Meetnet Biodiversiteit Zaanstad. De rapportage beschrijft welke soorten en soortgroepen worden gemonitord en welke methodieken hiervoor dienen te worden gebruikt. Hoe data in het veld dienen te worden verzameld, opgeslagen kunnen worden en hoe analyse en interpretatie van data kunnen worden uitgevoerd. Tevens komen eisen aan de waarnemer aan bod, evenals communicatie en samenwerking.

Trefwoorden: Biodiversiteit, Citizen Science, gemeente Zaanstad, Meetnet Biodiversiteit, Meetnet Biodiversiteit Zaanstad (MBZ)

Dit rapport is gratis te downloaden van https://doi.org/10.18174/440887 of op www.wur.nl/environmental-research (ga naar 'Wageningen Environmental Research' in de grijze balk onderaan). Wageningen Environmental Research verstrekt geen gedrukte exemplaren van rapporten.

(9) 2018 Wageningen Environmental Research (instituut binnen de rechtspersoon Stichting Wageningen Research), Postbus 47, 6700 AA Wageningen, T 03174807 00, E info.alterra@wur.nl, www.wur.nl/environmental-research. Wageningen Environmental Research is onderdeel van Wageningen University \& Research.

- Overname, verveelvoudiging of openbaarmaking van deze uitgave is toegestaan mits met duidelijke bronvermelding.

- Overname, verveelvoudiging of openbaarmaking is niet toegestaan voor commerciële doeleinden en/of geldelijk gewin.

- Overname, verveelvoudiging of openbaarmaking is niet toegestaan voor die gedeelten van deze uitgave waarvan duidelijk is dat de auteursrechten liggen bij derden en/of zijn voorbehouden.

Wageningen Environmental Research aanvaardt geen aansprakelijkheid voor eventuele schade voortvloeiend uit het gebruik van de resultaten van dit onderzoek of de toepassing van de adviezen.

Wageningen Environmental Research Rapport 2866 | ISSN 1566-7197

Foto omslag: Overzicht op Guisveld onderdeel van polder West-Zaan met een uitzicht op Zaanstad (Wormerveer). Foto: Tom Kisjes(C). 


\section{Inhoud}

$\begin{array}{ll}\text { Samenvatting } & \mathbf{5}\end{array}$

1

$\begin{array}{ll}\text { Inleiding } & \mathbf{7}\end{array}$

2

$\begin{array}{ll}\text { Welke soorten en soortgroepen? } & 8\end{array}$

2.1 Vaststellen van de definitieve lijst van soorten 8

2.2 Koppeling tussen soorten, soortgroepen en landschapstypen in Zaanstad 9

3

$\begin{array}{ll}\text { Monitoringsmethodiek per faunagroep en flora } & 18\end{array}$

3.1 Zoetwatervissen en brakwatervissen 18

3.2 Amfibieën en Reptielen $\quad 19$

3.2.1 Rugstreeppad 19

$\begin{array}{ll}3.2 .2 \text { Ringslang } & 19\end{array}$

$\begin{array}{lll}3.3 & \text { Vleermuizen } & 21\end{array}$

3.4 Overige zoogdieren $\quad 22$

$\begin{array}{lll}3.5 & \text { Dagvlinders } & 23\end{array}$

3.6 Glassnijder $\quad 24$

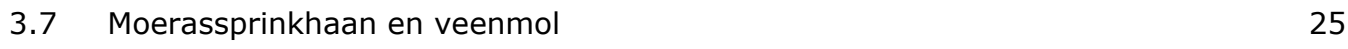

$\begin{array}{lll}3.8 & \text { Wilde bijen } & 26\end{array}$

$\begin{array}{lll}3.9 & \text { Vogels } & 27\end{array}$

3.9.1 Broedvogels van stedelijk gebied, bossen en parken 27

3.9.2 Broedvogels van moerassen, slootkanten en (natte) bossen 28

$\begin{array}{ll}3.9 .3 \text { Weidevogels } & 28\end{array}$

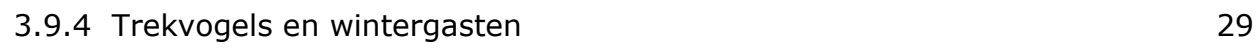

$\begin{array}{lll}3.10 & \text { Flora } & 30\end{array}$

$4 \quad$ Eisen aan de waarnemer $\quad 31$

5 Dataopslag $\quad 32$

5.1 Dataopslag in het veld $\quad 32$

5.2 Het opzetten van een database $\quad 32$

5.3 Aandacht van dataopslag bij gemeenteprojecten waarvoor natuurtoetsen zijn uitgevoerd 33

5.4 Opslag bij de Nationale Database Flora en Fauna (NDFF) 33

$\begin{array}{llr}6 & \text { Analyse en interpretatie } & 34\end{array}$

$7 \quad$ Communicatie en samenwerking $\quad 35$

7.1 Welke partijen worden bediend? $\quad 35$

7.2 Communicatie, samenwerking en Citizen Science 35

$\begin{array}{ll}\text { Literatuur } & \mathbf{3 7}\end{array}$ 
Bijlage 1 Huizen, erven, overig: stedelijk en landelijke (lint)bebouwing inclusief tuinen, erven, bestrating, (kade)muren

Bijlage 2 Broekbossen: elzen-, berken- en wilgenbroekbossen

Bijlage 3 Stadsparken: stadsparken en begraafplaatsen

Bijlage 4 Loofbos \& struweel: loofbos, houtwallen, bomenrijen, struweel inclusief mantel/zoom

Bijlage 5 Veenheide: vochtige laagveenheide

Bijlage 6 Rietland: alle typen rietland, inclusief jonge verlandingsstadia, exclusief verzuurde veenmosrietland en droog rietland

Bijlage 7 Veenmosrietland en veenhooiland: veenmosrietland en haarmosrietlanden, veenhooiland

Bijlage 8 Moeras en vochtige ruigte: niet tot weinig gemaaide moerasvegetatie en verruigde moerasvegetatie

Bijlage 9 Droge rietlanden en ruigte: onbeheerde, droge, verruigde terreinen

Bijlage 10 Kruidenrijk grasland: extensief beheerd grasland en schraalland

Bijlage 11 Plasdras: in het voorjaar nat tot zeer nat grasland

Bijlage 12 Wegberm: alle wegbermen, zowel schraal als rijk, intensief en extensief beheerd

Bijlage 13 Agrarisch grasland: intensief beheerd grasland met een hogere mestgift en een laag waterpeil

Bijlage 14 Plantsoengras: intensief beheerde plantsoenen (gemeentelijk groen)

Bijlage 15 Tijdelijke natuur Droog: ruderale en opgespoten terreinen met droge bodem

Bijlage 16 Tijdelijke natuur Nat: ruderale en opgespoten terreinen met vochtige tot natte bodem

Bijlage 17 Volkstuinen: volkstuinen, inclusief opgaande erfbeplanting

Bijlage 18 Bouwland: akkers

Bijlage 19 Brakwater: brakwater inclusief oeverzone/zoom

Bijlage 20 Zoetwater: zoetwater, inclusief oeverzone/zoom 


\section{Samenvatting}

Een motie van Groen Links binnen de gemeente Zaanstad, waarin het 'Monitoren van Biodiversiteit' als speerpunt staat gemeld, is de aanleiding voor de gemeente Zaanstad om te laten onderzoeken hoe biodiversiteit binnen de gemeentegrenzen kan worden gemeten en gevolgd.

Hiervoor heeft gemeente Zaanstad Wageningen Environmental Research (WENR) gevraagd voor het opzetten van een meetinstrument voor de biodiversiteit in de gemeente Zaanstad ofwel Meetnet Biodiversiteit Zaanstad (MBZ).

In de voorliggende rapportage wordt uiteengezet hoe het meetinstrument wordt opgezet en eruit kan zien. De vragen die worden beantwoord, zijn:

- Welke partijen worden bediend?

- Welke spelregels zijn er bij de monitoring?

- Hoe leg je de informatie vast?

- Hoe zorg je ervoor dat MBZ ook in de toekomst zijn vervolg krijgt?

De rapportage beschrijft welke soorten en soortgroepen worden gemonitord en welke methodieken hiervoor dienen te worden gebruikt. Hoe data in het veld dienen te worden verzameld, kunnen worden opgeslagen en hoe analyse en interpretatie van data kunnen worden uitgevoerd. Tevens komen eisen aan de waarnemer aan bod, evenals communicatie en samenwerking. 


\section{$1 \quad$ Inleiding}

Een motie van Groen Links binnen de gemeente Zaanstad, waarin het 'Monitoren van Biodiversiteit' als speerpunt staat gemeld, is de aanleiding voor de gemeente Zaanstad om te laten onderzoeken hoe biodiversiteit binnen de gemeente grenzen kan worden gemeten en gevolgd.

Uit het overleg tussen Wageningen Environmental Research en gemeente Zaanstad kwamen de volgende voornaamste opgaven naar voren:

1. Opzetten van een meetinstrument voor de biodiversiteit (Meetnet Biodiversiteit Zaanstad (MBZ)) in de gemeente Zaanstad.

2. Uitkomsten van het meetinstrument moet inzichtelijk maken hoe het is gesteld met de biodiversiteit binnen de gemeentegrenzen van Zaanstad.

3. De uitkomsten van Meetnet Biodiversiteit Zaanstad kunnen helpen bij risico-inschatting van projecten en het sturen van verschillende beleidsvraagstukken binnen de gemeente Zaanstad (bijvoorbeeld waar wel of geen economische activiteiten zoals woningbouw of infrastructuur kunnen plaatsvinden, waar wel of geen mitigatie/compensatie dient te worden doorgevoerd of waar juiste gerichte soortbeschermingsmaatregelen moeten worden genomen).

De voorliggende rapportage behelst alleen de stap (Stap 1) waarin het meetinstrument wordt ontwikkeld en opgezet, ofwel hoe ziet het eruit, en waarin de volgende vragen op verzoek van gemeente Zaanstad worden beantwoord:

- Welke partijen worden bediend?

- Welke spelregels zijn er bij de monitoring?

- Hoe leg je informatie vast?

- Hoe zorg je ervoor dat het Meetnet Biodiversiteit Zaanstad ook in de toekomst zijn vervolg krijgt?

\section{Biodiversiteit}

Planten en dieren verrichten allerlei (ecosysteem)diensten voor onze samenleving, hun gebrek aan vitaliteit treft uiteindelijk ook onze overlevingskansen. Volgens het Stockholm Resilience Centre is biodiversiteitsverlies de grootste bedreiging voor de leefbaarheid van onze aarde, groter dan klimaatverandering (Rockström et al. Nature, 2009)! Er is, kortom, urgentie om de biodiversiteit in onze leefomgeving op peil te houden, te beginnen met soorten die momenteel in hun voortbestaan worden bedreigd (Rode Lijst-soorten). Daarnaast is het ook belangrijk om soorten die nu nog algemeen voorkomen niet te laten afnemen en om mensen die biodiversiteit te laten beleven, zodat zij de waarde daarvan blijven inzien. 


\section{$2 \quad$ Welke soorten en soortgroepen?}

\subsection{Vaststellen van de definitieve lijst van soorten}

Bij voorkeur worden zogeheten paraplusoorten gemonitord die een bepaalde levensgemeenschap of habitattype vertegenwoordigen. Als je weet dat het met de betreffende paraplusoort (kritische soort(en)) goed gaat, dan weet men automatisch dat het ook goed gaat met die levensgemeenschap. Op die manier hoeft men niet elke soort te monitoren om iets te kunnen zeggen over de biodiversiteit.

Diersoorten zijn geselecteerd op basis van de Natura 2000-doelsoorten, SNL-doelsoorten van de provincie en de Natuuratlas Zaanstad (Provincie Noord-Holland Ontwerp-Natuurbeheerplan 2018; Provincie Noord-Holland. Natura 2000 beheerplan Ilperveld, Varkensland, Oostzanerveld en Twiske 2016-2022.; Provincie Noord-Holland. Natura 2000-beheerplan Wormer- en Jisperveld \& Kalverpolder2016-2022; Provincie Noord-Holland. Natura 2000-beheerplan Polder Westzaan 20162022; Veer et al. 2012). Daarnaast is de lijst met bijen geselecteerd op basis van de Natuuratlas Zaanstad aangevuld met soorten uit waarneming.nl.

Plantensoorten zijn geselecteerd op basis van de lijst met waardevolle natuur uit de Natuuratlas Zaanstad (Veer et al. 2012). Daarnaast is monitoring van de flora in Natura 2000-habitattypen en plantengemeenschappen van belang. Het betreft de Natura 2000-habitattypen:

N2000 Ilperveld, Varkensland, Oostzanerveld en Twiske (2): Kranswierwateren (H3140), Vochtige heiden, laagveengebied (H4010B), Ruigten en zomen, harig wilgenroosje (H6430B), Overgangs- en trilvenen, veenmosrietlanden (H7140B), Veenbossen, hoogveenbossen (H91D0)

N2000 Wormer- en Jisperveld \& Kalverpolder (3): Vochtige heiden, laagveengebied (H4010B), Ruigten en zomen, harig wilgenroosje (H6430B), Overgangs- en trilvenen, veenmosrietlanden (H7140B), Veenbossen, hoogveenbossen (H91D0).

N2000 Polder Westzaan (4): Vochtige heiden, laagveengebied (H4010B), Ruigten en zomen, harig wilgenroosje (H6430B), Overgangs- en trilvenen, veenmosrietlanden (H7140B) Veenbossen, hoogveenbossen (H91D0).

Het betreft de plantengemeenschappen:

Associaties van zilte waterranonkel (5Aa2), groot nimfkruid (5Aa3), kamgrasweide (16Bc1), lidsteng (8Aa1), ruwe bies (8Bb2), veenmosrietland (9Aa2), moerasheide (11Ba2), moeraszoutgras \& fioringras (12Ba2), muurvaren (21Ab01), tongvaren (21Ab2), stranduizendguldenkruid \& krielparnassia (27Aa2), echte koekoeksbloem \& hertshooi (16Ab3).

De natuurkwaliteit in het Natuur Netwerk Nederland, inclusief de Natura 2000-gebieden, wordt al gemonitord volgens een landelijk vastgestelde werkwijze ("Werkwijze monitoring en beoordeling NNN/N2000 https://www.ndff.nl/overdendff/validatie/protocollen/"). Ook zijn soorten en habitattypen meegenomen die kenmerkend zijn voor de Natura 2000-gebieden. Daarnaast zijn soorten opgenomen uit de lijst met waardevolle plantengemeenschappen voor zover ze niet in de lijst van planten voorkomen met waardevolle natuur uit de Natuuratlas Zaanstad.

Het vaststellen van de definitieve lijst van soorten of soortgroepen die worden gemonitord, gaat in samenspraak met gemeente Zaanstad en bij voorkeur ook met groene organisaties die binnen de gemeente actief zijn. Zie potentiële organisatie in hoofdstuk 7.2. Let wel: Dit is geen must, maar zal het draagvlak voor Meetnet Biodiversiteit Zaanstad vergroten en tevens kunnen deze organisaties t.z.t. participeren in de monitoring (Citizen Science). 


\subsection{Koppeling tussen soorten, soortgroepen en landschapstypen in Zaanstad}

Om te bepalen in welk landschapstype transecten moeten liggen voor de soortgroepen, zijn soorten toegewezen aan landschapstypen (deze zijn in de Natuur Atlas Zaanstad bepaald op basis van de fysisch-geografische ondergrond binnen de gemeente Zaanstad). Figuur 1 laat het verschillende grondgebruik (basis voor de latere landschapstypen) op kaart binnen gemeente Zaanstad zien. De toegewezen soorten zijn indicatorsoorten voor de kwaliteit van de typen, maar kunnen uiteraard in sommige gevallen ook buiten de typen voorkomen (ofwel geografische spreiding over de verschillende typen bodemgebruik zal bepalend zijn voor het aantal transecten, plots etc.). Toewijzing is gedaan op basis van expertkennis en met behulp van diverse handboeken, atlassen en websites over de ecologie. Voor de broedvogels geldt dat deze vooral op broedhabitat zijn ingedeeld. Voor de niet-broedvogels geldt dat deze op basis van hun foerageer-/verblijfgebied zijn ingedeeld. 


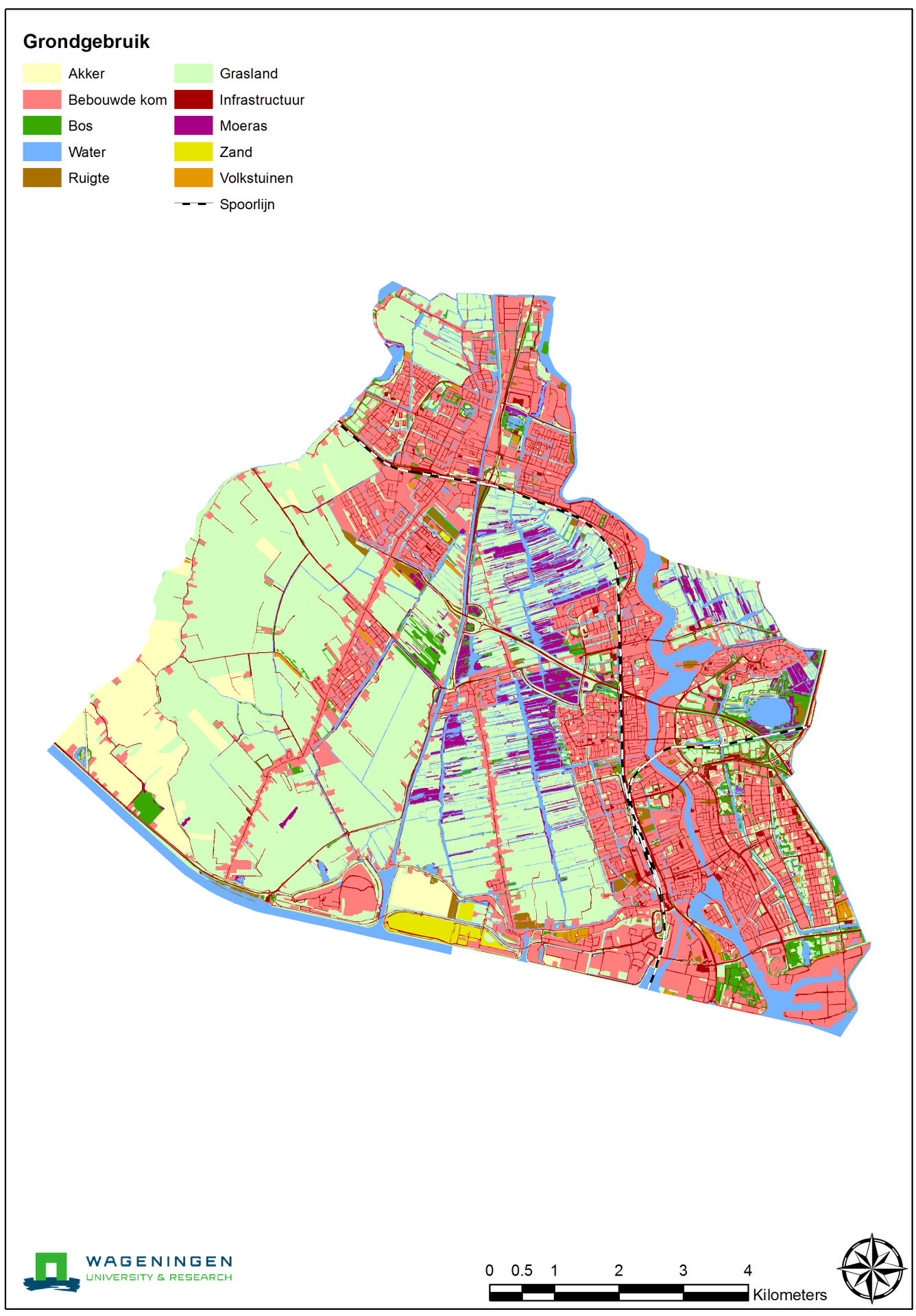

Figuur 1 Grondgebruik binnen gemeente Zaanstad, naar voorbeeld van Veer et al. (2012). 
De volgende landschapstypen in de gemeente Zaanstad zijn onderscheiden op basis van Veer et al. (2012):

1. Huizen, erven, overig: Stedelijk en landelijke (lint)bebouwing, inclusief tuinen, erven, bestrating, (kade)muren.

2. Broekbossen: Elzen-, berken- en wilgenbroekbossen

3. Stadsparken: Stadsparken en begraafplaatsen.

4. Naaldbos: Naaldbos inclusief mantel/zoom.

5. Loofbos \& struweel: Loofbos, houtwallen, bomenrijen, struweel inclusief mantel/zoom.

6. Veenheide: Vochtige laagveenheide.

7. Rietland: Alle typen rietland, inclusief jonge verlandingsstadia, exclusief verzuurde veenmosrietland en droog rietland.

8. Veenmosrietland en veenhooiland: Veenmosrietland en haarmosrietlanden, veenhooiland.

9. Moeras en vochtige ruigte: Niet tot weinig gemaaide moerasvegetatie en verruigde moerasvegetatie.

10. Droge rietlanden en ruigte: Onbeheerde droge verruigde terreinen.

11. Kruidenrijk grasland: Extensief beheerd grasland en schraalland.

12. Plasdras: In het voorjaar nat tot zeer nat grasland.

13. Wegberm: Alle wegbermen, zowel schraal als rijk, intensief en extensief beheerd.

14. Agrarisch grasland: Intensief beheerd grasland met een hogere mestgift en laag waterpeil.

15. Spoorberm: Zandige taluds met grind/kiezels.

16. Plantsoengras: Intensief beheerde plantsoenen (gemeentelijk groen).

17. Tijdelijke natuur Droog: Ruderale en opgespoten terreinen met droge bodem.

18. Tijdelijke natuur Nat: Ruderale en opgespoten terreinen met vochtige tot natte bodem.

19. Volkstuinen: Volkstuinen inclusief opgaande erfbeplanting.

20. Bouwland: Akkers.

21. Brak water: Brak water inclusief oeverzone/zoom.

22. Zoet water: Zoet water inclusief oeverzone/zoom.

In Bijlage 1 tot en met 20 worden de kaarten van de bovenstaande landschapstypen gepresenteerd (let op de nummering in de bijlage correspondeert niet met de bovenstaande nummering) m.u.v. landschapstype 'Naaldbos: Naaldbos inclusief mantel/zoom' en 'Spoorberm: Zandige taluds met grind/kiezels'. Type Naaldbos is met 0,5 ha alleen aanwezig in 'Veldpark'. Besloten is om hier geen kaart van te maken. De spoorbermen staan weergegeven in Figuur 1. 
In Tabel 1 tot en met Tabel 13 wordt de koppeling tussen soortgroep en habitattype weergegeven.

Tabel 1 Brakwatervissen versus habitattypen in de gemeente Zaanstad.

\begin{tabular}{|c|c|c|c|c|c|c|c|c|c|c|c|c|c|c|c|c|c|c|c|c|c|c|}
\hline Brakwatervissen & \multicolumn{22}{|c|}{ Habitattypen } \\
\hline Dikkopje & & & & & & & & & & & & & & & & & & & & & $x$ & \\
\hline Glasgrondel & & & & & & & & & & & & & & & & & & & & & $x$ & \\
\hline Slakdolf & & & & & & & & & & & & & & & & & & & & & $x$ & \\
\hline Vijfdradige meun & & & & & & & & & & & & & & & & & & & & & $x$ & \\
\hline Zwarte grondel & & & & & & & & & & & & & & & & & & & & & $x$ & \\
\hline
\end{tabular}

Tabel 2 Zoetwatervissen versus habitattypen in de gemeente Zaanstad.

\begin{tabular}{|c|c|c|c|c|c|c|c|c|c|c|c|c|c|c|c|c|c|c|c|c|c|c|}
\hline Zoetwatervissen & \multicolumn{22}{|c|}{ Habitattypen } \\
\hline Bittervoorn & & & & & & & & & & & & & & & & & & & & & & $x$ \\
\hline Kroeskarper & & & & & & & & & & & & & & & & & & & & & & $x$ \\
\hline Paling & & & & & & & & & & & & & & & & & & & & & $x$ & $x$ \\
\hline Rivierprik & & & & & & & & & & & & & & & & & & & & & $x$ & $x$ \\
\hline Vetje & & & & & & & & & & & & & & & & & & & & & & $x$ \\
\hline
\end{tabular}

Tabel 3 Amfibie versus habitattypen in de gemeente Zaanstad.

\begin{tabular}{l|c|c|c|c|c|c|c|c|c|c|c|c|c|c|c|c|c|c|c|c|c|c|}
\hline Amfibie & \multicolumn{10}{|c|}{ Habitattypen } \\
\hline Soort & 1 & 2 & 3 & 4 & 5 & 6 & 7 & 8 & 9 & 10 & 11 & 12 & 13 & 14 & 15 & 16 & 17 & 18 & 19 & 20 & 21 & 22 \\
\hline Rugstreeppad & $\mathrm{x}$ & $\mathrm{x}$ & & & & $\mathrm{x}$ & & & $\mathrm{x}$ & & & $\mathrm{x}$ & & & & & & $\mathrm{x}$ & $\mathrm{x}$ & & $\mathrm{x}$ \\
\hline
\end{tabular}

Tabel 4 Reptiel versus habitattypen in de gemeente Zaanstad.

\begin{tabular}{|l|c|c|c|c|c|c|c|c|c|c|c|c|c|c|c|c|c|c|c|c|c|c|}
\hline Reptiel & \multicolumn{10}{|c|}{ Habitattypen } \\
\hline Soort & 1 & 2 & 3 & 4 & 5 & 6 & 7 & 8 & 9 & 10 & 11 & 12 & 13 & 14 & 15 & 16 & 17 & 18 & 19 & 20 & 21 & 22 \\
\hline Ringslang & & $\mathrm{x}$ & $\mathrm{x}$ & & & & $\mathrm{x}$ & $\mathrm{x}$ & $\mathrm{x}$ & & $\mathrm{x}$ & $\mathrm{x}$ & & & & & & $\mathrm{x}$ & $\mathrm{x}$ & & $\mathrm{x}$ \\
\hline
\end{tabular}


Tabel $5 \quad$ Vleermuizen versus habitattypen in de gemeente Zaanstad.

\begin{tabular}{|c|c|c|c|c|c|c|c|c|c|c|c|c|c|c|c|c|c|c|c|c|c|c|}
\hline Vleermuizen & \multicolumn{22}{|c|}{ Habitattypen } \\
\hline $\begin{array}{l}\text { Gewone } \\
\text { Dwergvleermuis }\end{array}$ & $x$ & $x$ & $x$ & $x$ & $x$ & & & & & & & & & & & & & & $x$ & & & \\
\hline $\begin{array}{l}\text { Gewone } \\
\text { grootoorvleermuis }\end{array}$ & $x$ & & $x$ & & $x$ & & & & & & & & & & & & & & $x$ & & & \\
\hline Meervleermuis & $x$ & & & & & & & & & & & & & & & & & & & & $x$ & $x$ \\
\hline $\begin{array}{l}\text { Ruige } \\
\text { dwergvleermuis }\end{array}$ & $x$ & $x$ & $x$ & & $x$ & & & & & & $\mathrm{x}$ & & & $x$ & & & & & & & $x$ & $x$ \\
\hline Watervleermuis & $x$ & & $x$ & & $x$ & & & & & & & & & & & & & & & & & $x$ \\
\hline
\end{tabular}

Tabel 6 Overige zoogdieren versus habitattypen in de gemeente Zaanstad.

\begin{tabular}{|c|c|c|c|c|c|c|c|c|c|c|c|c|c|c|c|c|c|c|c|c|c|c|}
\hline Overige zoogdieren & \multicolumn{22}{|c|}{ Habitattypen } \\
\hline Soort & 1 & 2 & 3 & 4 & 5 & 6 & 7 & 8 & 9 & 10 & 11 & 12 & 13 & 14 & 15 & 16 & 17 & 18 & 19 & 20 & 21 & 22 \\
\hline Bunzing & & $x$ & & & $x$ & & & & & & & & & & & & & & $x$ & & $x$ & $x$ \\
\hline Waterspitsmuis & & & & & & & $x$ & & $x$ & & $x$ & & & & & & & $x$ & & & & $x$ \\
\hline Wezel & $x$ & $x$ & $x$ & & $x$ & & & & $x$ & $x$ & & & & & & & $x$ & & $x$ & $x$ & & \\
\hline
\end{tabular}

Tabel 7 Dagvlinders versus habitattypen in de gemeente Zaanstad.

\begin{tabular}{|c|c|c|c|c|c|c|c|c|c|c|c|c|c|c|c|c|c|c|c|c|c|c|}
\hline Dagvlinders & \multicolumn{22}{|c|}{ Habitattypen } \\
\hline Soort & 1 & 2 & 3 & 4 & 5 & 6 & 7 & 8 & 9 & 10 & 11 & 12 & 13 & 14 & 15 & 16 & 17 & 18 & 19 & 20 & 21 & 22 \\
\hline Argusvlinder & & & & & & & & & & & $x$ & & $x$ & & $x$ & $x$ & $x$ & & $x$ & & & \\
\hline Boomblauwtje & $x$ & $x$ & $x$ & $x$ & $x$ & & & & $x$ & $x$ & & & & & & & $x$ & & $x$ & & & \\
\hline Bruin blauwtje & & & & & & & & & & & & & $x$ & & $x$ & & $x$ & & & & & \\
\hline Citroenvlinder & $x$ & & $x$ & & $x$ & & & & & & & & & & & & & & $x$ & & & \\
\hline Geelsprietdikkopje & & & & & & & & & & & & & $x$ & & $x$ & & $x$ & & & & & \\
\hline Gehakkelde aurelia & $x$ & $x$ & $x$ & & $x$ & & & & & & & & & & & & & & $x$ & & & \\
\hline Hooibeestje & & & & & & & & & & & $x$ & & $x$ & & $x$ & & $x$ & & & & & \\
\hline Oranjetipje & $x$ & & $x$ & & $x$ & & & & & & $x$ & & $x$ & & & $x$ & & & $x$ & & & \\
\hline Zwartsprietdikkopje & & & & & & & & & & & & & $x$ & & $x$ & $x$ & $x$ & & & & & \\
\hline
\end{tabular}

Tabel 8 Libelle versus habitattypen in de gemeente Zaanstad.

\begin{tabular}{l|c|c|c|c|c|c|c|c|c|c|c|c|c|c|c|c|c|c|c|c|c|c|}
\hline Libelle & Habitatypen \\
\hline Soort & 1 & 2 & 3 & 4 & 5 & 6 & 7 & 8 & 9 & 10 & 11 & 12 & 13 & 14 & 15 & 16 & 17 & 18 & 19 & 20 & 21 & 22 \\
\hline Glassnijder & & & & & & & $\mathrm{x}$ & $\mathrm{x}$ & $\mathrm{x}$ & & & $\mathrm{x}$ & & & & & & & & & $\mathrm{x}$ \\
\hline
\end{tabular}


Tabel 9 Sprinkhaan en krekel versus habitattypen in de gemeente Zaanstad.

\begin{tabular}{|c|c|c|c|c|c|c|c|c|c|c|c|c|c|c|c|c|c|c|c|c|c|c|}
\hline Sprinkhaan en & \multicolumn{22}{|c|}{ Habitattypen } \\
\hline Soort & 1 & 2 & 3 & 4 & 5 & 6 & 7 & 8 & 9 & 10 & 11 & 12 & 13 & 14 & 15 & 16 & $17 \mid$ & 18 & 19 & 20 & 21 & 22 \\
\hline Veenmol & $x$ & & & & & $x$ & & $x$ & $x$ & & $x$ & & & $x$ & & & & & $x$ & $x$ & & \\
\hline
\end{tabular}

Tabel 10 Wilde bijen versus habitattypen in de gemeente Zaanstad.

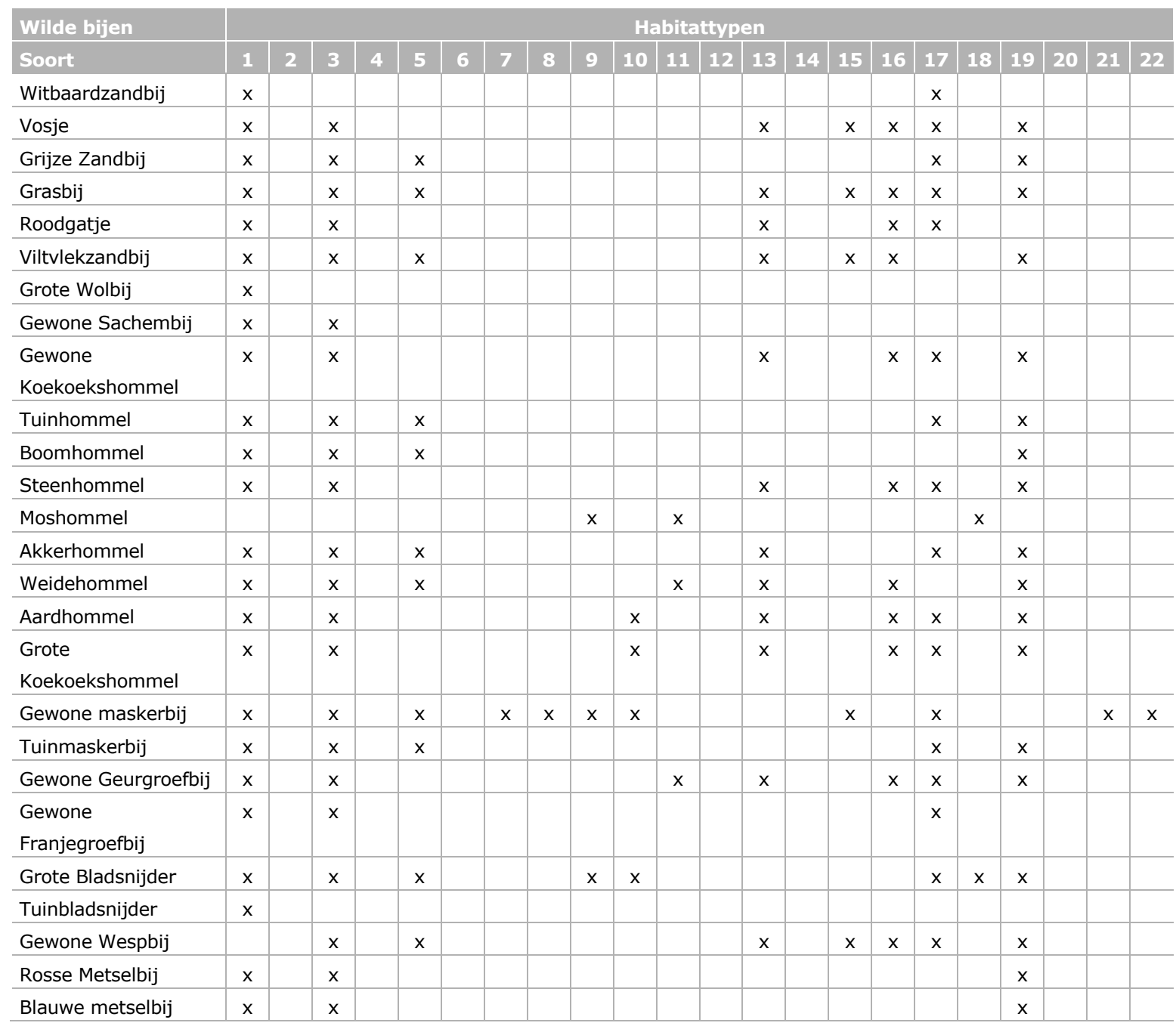


Tabel 11 Broedvogels versus habitattypen in de gemeente Zaanstad.

\begin{tabular}{|c|c|c|c|c|c|c|c|c|c|c|c|c|c|c|c|c|c|c|c|c|c|c|}
\hline Broedvogels & & & & & & & & & & & bita & ttyp & & & & & & & & & & \\
\hline Soort & 1 & 2 & 3 & 4 & 5 & 6 & 7 & 8 & 9 & 10 & 11 & 12 & 13 & 14 & 15 & 16 & 17 & 18 & 19 & 20 & 21 & 22 \\
\hline Baardman & & & & & & & $x$ & $x$ & $x$ & & & & & & & & & & & & $x$ & $x$ \\
\hline Blauwe kiekendief* & & & & & & & & $x$ & & & $x$ & & & & & & & & & $x$ & & \\
\hline Boerenzwaluw & $x$ & & & & & & & & & & & & & & & & & & & & & \\
\hline Bontbekplevier & & & & & & & & & & & & & & & & & $x$ & $x$ & & & & \\
\hline Braamsluiper & $x$ & & $x$ & $x$ & $x$ & & & & & & & & & & & & & & & & & \\
\hline Bruine kiekendief & & & & & & & & $x$ & $x$ & $x$ & & & & & & & & & & $x$ & & \\
\hline Dodaars & & & & & & & & & $x$ & & & & & & & & & & & & & $x$ \\
\hline Gele kwikstaart & & & & & & & & $x$ & & & $x$ & & & $x$ & & & & & & $x$ & & \\
\hline Gierzwaluw & $x$ & & & & & & & & & & & & & & & & & & & & & \\
\hline Graspieper & & & & & & $x$ & & $x$ & & & $x$ & & & $x$ & & & & & & & & \\
\hline Grauwe kiekendief & & & & & & & & & & & & & & & & & $x$ & $x$ & & $x$ & & \\
\hline Grauwe vliegenvanger & $x$ & & $x$ & & $x$ & & & & & & & & & & & & & & $x$ & & & \\
\hline Groene specht & & & $x$ & & $x$ & & & & & & & & & & & & & & $x$ & & & \\
\hline Grote karekiet & & & & & & & $x$ & & $x$ & & & & & & & & & & & & & $x$ \\
\hline Grote Lijster & & & $x$ & & $x$ & & & & & & & & & & & & & & $x$ & & & \\
\hline Grutto & & & & & & & & & & & $x$ & $x$ & & $x$ & & & & & & & & \\
\hline Houtduif & $x$ & & $x$ & & $x$ & & & & & & & & & & & & & & $x$ & & & \\
\hline Huismus & $x$ & & & & & & & & & & & & & & & & & & & & & \\
\hline Huiszwaluw & $x$ & & & & & & & & & & & & & & & & & & & & & \\
\hline IJsvogel & $x$ & & $x$ & & & & & & $x$ & & & & & & & & & & & & & $x$ \\
\hline Kemphaan & & & & & & & & & & & $x$ & $x$ & & & & & & & & & & \\
\hline Kerkuil & $x$ & & & & & & & & & & & & & & & & & & & $x$ & & \\
\hline Kievit & & & & & & & & & & & $x$ & $x$ & & $x$ & & & & & & $x$ & & \\
\hline Kleinst waterhoen & & & & & & & & & $x$ & & & & & & & & & & & & & $x$ \\
\hline Kluut & & & & & & & & & & & & $x$ & & & & & & $x$ & & & & \\
\hline Kneu & & & & & $x$ & & & & & & & & & & & & & & & & & \\
\hline Koekoek & & $x$ & $x$ & & $x$ & & $x$ & $x$ & $x$ & & & & & & & & & & & & & \\
\hline Kramsvogel & & & & & $x$ & & & & & & & & & & & & & & & & & \\
\hline Kwartelkoning & & & & & & & & $x$ & & & $x$ & & & & & & & & & & & \\
\hline Matkop & & $x$ & $x$ & & $x$ & & & & & $x$ & & & & & & & & & $x$ & & & \\
\hline Nachtegaal & & $x$ & $x$ & & $x$ & & & & $x$ & & & & & & & & & & & & & \\
\hline Patrijs & & & & & & & & & & & $x$ & & & $x$ & & & & & & $x$ & & \\
\hline Porseleinhoen & & & & & & & $x$ & & $x$ & & & & & & & & & & & & & \\
\hline Ransuil & & $x$ & $x$ & $x$ & $x$ & & & & & & & & & & & & & & $x$ & & & \\
\hline Rietzanger & & & & & & & $x$ & $x$ & $x$ & $x$ & & & & & & & & $x$ & & & & \\
\hline Ringmus & $x$ & & $x$ & & $x$ & & & & & & & & & & & & & & $x$ & & & \\
\hline Roek & $x$ & $x$ & $x$ & & $x$ & & & & & & & & & & & $x$ & & & & & & \\
\hline Roerdomp & & & & & & & $x$ & & $x$ & & & & & & & & & & & & & $x$ \\
\hline Scholekster & $x$ & & & & & & & & & & $x$ & & & $x$ & & & & & & $x$ & & \\
\hline Slechtvalk & $x$ & & & & & & & & & & & & & & & & & & & & & \\
\hline Slobeend & & & & & & & & & & & $x$ & $x$ & & & & & & & & & $x$ & $x$ \\
\hline Snor & & & & & & & $x$ & & $x$ & & & & & & & & & & & & & $x$ \\
\hline Spotvogel & $x$ & & $x$ & & $x$ & & & & & & & & & & & & & & & & & \\
\hline Spreeuw & $x$ & & $x$ & & $x$ & & & & & & & & & & & $x$ & & & $x$ & & & \\
\hline Strandplevier & & & & & & & & & & & & & & & & & $x$ & $x$ & & & & \\
\hline Steenuil & $x$ & & & & $x$ & & & & & & & & & & & & & & & & & \\
\hline Torenvalk & $x$ & & & & $x$ & & & & & & $x$ & & & & & & & & & & & \\
\hline Tureluur & & & & & & & & $x$ & & & $x$ & $x$ & & $x$ & & & & & & & & \\
\hline Veldleeuwerik & & & & & & $x$ & & $x$ & & & $x$ & & & $x$ & & & & & & $x$ & & \\
\hline Velduil & & & & & & & & $x$ & & & $x$ & & & $x$ & & & & & & $x$ & & \\
\hline Visdief & $x$ & & & & & & & & & & & & & & & & $x$ & $x$ & & & & \\
\hline Watersnip & & & & & & $x$ & $x$ & $x$ & $x$ & & $x$ & $x$ & & & & & & & & & & $x$ \\
\hline Wintertaling & & & & & & & & & & & $x$ & $x$ & & & & & & & & & & $x$ \\
\hline Wulp & & & & & & $x$ & $x$ & $x$ & & & $x$ & $x$ & & & & & & & & $x$ & & \\
\hline Zomertaling & & & & & & & & & $x$ & & $x$ & $x$ & & & & & & & & & & $x$ \\
\hline Zomertortel & $x$ & & $x$ & & $x$ & & & & & & & & & & & & & & & & & \\
\hline Zwarte stern & & & & & & & & & & & & & & & & & & & & & & $x$ \\
\hline
\end{tabular}


Tabel 12 Niet-broedvogels: trekvogels en wintergasten versus habitattypen in de gemeente Zaanstad.

\begin{tabular}{|c|c|c|c|c|c|c|c|c|c|c|c|c|c|c|c|c|c|c|c|c|c|c|}
\hline Niet Broedvogels & \multicolumn{22}{|c|}{ Habitattypen } \\
\hline Soort & 1 & 2 & 3 & 4 & 5 & 6 & 7 & 8 & 9 & 10 & 11 & 12 & 13 & 14 & 15 & 16 & 17 & 18 & 19 & 20 & 21 & 22 \\
\hline Geelgors & $x$ & $x$ & $x$ & $x$ & $x$ & & & & & & & & & & & & & & & $x$ & & \\
\hline Grauwe gans & & & & & & & & $x$ & & & $x$ & $x$ & & $x$ & & & & & & $x$ & & \\
\hline Grutto & & & & & & & & & & & $x$ & $x$ & & & & & & & & & & \\
\hline Kievit & & & & & & & & & & & $x$ & $x$ & & $x$ & & & & & & $x$ & & \\
\hline Kleine zwaan & & & & & & & & $x$ & & & $x$ & & & $x$ & & & & & & $x$ & & $x$ \\
\hline Krakeend & & & & & & & & & & & & & & & & & & & & & $x$ & $x$ \\
\hline Meerkoet & & & $x$ & & & & & & & & & $x$ & & & & & & & & & $x$ & $x$ \\
\hline Smient & & & & & & & & & & & $x$ & & & $x$ & & & & & & & $x$ & $x$ \\
\hline Wilde zwaan & & & & & & & & & & & $x$ & & & $x$ & & & & & & $x$ & & $x$ \\
\hline Wulp & & & & & & $x$ & $x$ & $x$ & & & $x$ & & & $x$ & & & & & & $x$ & & \\
\hline
\end{tabular}


Tabel 13 Planten versus habitattypen in de gemeente Zaanstad.

\begin{tabular}{|c|c|c|c|c|c|c|c|c|c|c|c|c|c|c|c|c|c|c|c|c|c|c|}
\hline Planten & & & & & & & & & & & bita & ttype & & & & & & & & & & \\
\hline Soort & 1 & 2 & 3 & 4 & 5 & 6 & 7 & 8 & 9 & 10 & 11 & 12 & 13 & 14 & 15 & 16 & 17 & 18 & 19 & 20 & 21 & 22 \\
\hline Aardaker & & & $x$ & & $x$ & & & & & & & & $x$ & & $x$ & & $x$ & & & & & \\
\hline Bevertjes & & & & & & & & $x$ & & & $x$ & & $x$ & & & & & & & & & \\
\hline Bijenorchis & & & $x$ & & $x$ & & & & & & $x$ & & $x$ & & $x$ & & $x$ & & & & & \\
\hline Blauwe bremraap & $x$ & & & & & & & & & & & & $x$ & & $x$ & & $x$ & & $x$ & & & \\
\hline Bosanemoon & & & $x$ & & $x$ & & & & & & & & & & & & & & & & & \\
\hline Brede orchis & & & & & & & & $x$ & & & & & $x$ & & & & & $x$ & & & & \\
\hline Brede wespenorchis & & & & & & & & & & & & & & & & & & & & & & \\
\hline Brede waterpest & & & & & & & & & & & & & & & & & & & & & $x$ & $x$ \\
\hline Echt lepelblad & & & & & & & $x$ & $x$ & $x$ & & & & & & & & & & & & $x$ & \\
\hline Echte koekoeksbloem & & & & & & & $x$ & $x$ & & & $x$ & & $x$ & & & & & $x$ & & & & $x$ \\
\hline Fioringras & & $x$ & & & & & $x$ & & & & & $x$ & $x$ & & & & & $x$ & & & $x$ & \\
\hline Gewone agrimonie & & & & & $x$ & & & & & & $x$ & & $x$ & & $x$ & & & & $x$ & $x$ & & \\
\hline Gewone vogelmelk & & & $x$ & & $x$ & & & & & & $x$ & & $x$ & & & $x$ & & & $x$ & $x$ & & \\
\hline Graslathyrus & & & $x$ & & $x$ & & & & & & & & $x$ & & & & $x$ & & & $x$ & & \\
\hline Groot nimfkruid & & & & & & & & & & & & & & & & & & & & & $x$ & $x$ \\
\hline Harlekijn & & & & & & & & $x$ & & & $x$ & & & & & & & & & & & \\
\hline Heemst & & & & & & & $x$ & $x$ & $x$ & & & & & & & & & & & & & \\
\hline Hondskruid & & & & & & & & & & & $x$ & & $x$ & & $x$ & & $x$ & & & & & \\
\hline Kamgras & & & $x$ & & & & & & & & $x$ & & & $x$ & & & & & & & & \\
\hline Kleine kaardebol & & & $x$ & & $x$ & & & & & & & & & & $x$ & & & & & & & \\
\hline Kleine pimpernel & & & & & & & & & & & & & $x$ & & $x$ & & & & & & & \\
\hline Kleverige reigersbek & & & & & & & & & & & $x$ & & $x$ & & $x$ & & $x$ & & & & & \\
\hline Koningsvaren & & $x$ & & & $x$ & & & $x$ & & & & & & & & & & & & & & $x$ \\
\hline Krabbenscheer & & & & & & & & & & & & & & & & & & & & & $x$ & $x$ \\
\hline Lidsteng & & & & & & & & & & & & & & & & & & & & & & $x$ \\
\hline Moerasbasterdwederik & & & & & & & $x$ & $x$ & $x$ & & & & & & & & & & & & & \\
\hline Moeraswespenorchis & & & & & & & $x$ & & $x$ & & & & $x$ & & & & & $x$ & & & & \\
\hline Moeraszoutgras & & & & & & & $x$ & & $x$ & & $x$ & & $x$ & & & & & $x$ & & & $x$ & \\
\hline Oosterse morgenster & & & & & & & & & & & $x$ & & $x$ & & & & & & & & & \\
\hline Paarse morgenster & & & & & & & & & & $x$ & & & $x$ & & & & $x$ & & & & & \\
\hline Rietorchis & & & & & & & $x$ & $x$ & & & & & $x$ & & $x$ & & & $x$ & & & & \\
\hline Rode ogentroost & & & & & & & & & & & & & $x$ & & & & & $x$ & & $x$ & $x$ & $x$ \\
\hline Ronde zonnedauw & & & & & & $x$ & & $x$ & & & & & & & & & & & & & & \\
\hline Ruwe bies & & & & & & & & & & & & & $x$ & & & & & $x$ & & & $x$ & \\
\hline Selderij & & & & & & & & & $x$ & & $x$ & & & & & & & $x$ & & & & \\
\hline Sierlijke vetmuur & $x$ & & & & & & & $x$ & & & & & & & & & & $x$ & & & & \\
\hline Slanke mantelanjer & $x$ & & & & & & & & & & & & $x$ & & & & $x$ & & & & & \\
\hline Snavelruppia & & & & & & & & & & & & & & & & & & & & & $x$ & \\
\hline Steenbreekvaren & $x$ & & & & & & & & & & & & & & & & & & & & & \\
\hline $\begin{array}{l}\text { Strandduizend- } \\
\text { guldenkruid }\end{array}$ & & & & & & & & & & & $x$ & & $x$ & & & & & $x$ & & & & \\
\hline Tongvaren & $x$ & & & & & & & & & & & & & & & & & & & & & \\
\hline Tripmadam & $x$ & & & & & & & & & & & & & & & & & & & & & \\
\hline Veenmosorchis & & & & & & & & $x$ & & & & & & & & & & & & & & \\
\hline Veenreukgras & & & & & & & $x$ & $x$ & $x$ & & & & $x$ & & & & & & & & & $x$ \\
\hline Veldgerst & & & & & & & & $x$ & & & $x$ & & & & & & & & & & & \\
\hline Vleeskleurige orchis & & & & & & & $x$ & $x$ & $x$ & & & & & & & & & $x$ & & & & \\
\hline Welriekende nachtorchis & & $x$ & & & $x$ & & $x$ & $x$ & & & & & $x$ & & $x$ & & & $x$ & & & & \\
\hline Wondklaver & & & & & & & & & & & & & $x$ & & $x$ & & $x$ & & & & & \\
\hline Zilt torkruid & & & & & & & & & $x$ & & $x$ & & & & & & & & & & $x$ & \\
\hline Zilte waterranonkel & & & & & & & & & & & & & & & & & & & & & $x$ & \\
\hline Elzenmos & & $x$ & & & & & & $x$ & & & & & & & & & & & & & & \\
\hline Glanzend veenmos & & & & & & $x$ & & $x$ & & & & & & & & & & & & & & \\
\hline Hoogveenmos & & $x$ & & & & $x$ & & $x$ & & & & & & & & & & & & & & \\
\hline Moerasgaffeltand & & $x$ & & & & & & $x$ & & & & & & & & & & & & & & \\
\hline Rood veenmos & & & & & & $x$ & & $x$ & & & & & & & & & & & & & & \\
\hline
\end{tabular}




\section{Monitoringsmethodiek per faunagroep en flora}

In dit hoofdstuk komt voor de verschillende soortgroepen de monitoringsmethodiek aan bod.

Beschreven worden het landschapstype waarin transecten, plots e.d. komen te liggen, de werkwijze en wat er dient te worden geregistreerd. De faunagroepen waar het om gaat, zijn: zoetwatervissen en brakwatervissen, amfibieën en reptielen en in het bijzonder de rugstreeppad en ringslang, vleermuizen, overige zoogdieren, dagvlinders, glassnijder, moerassprinkhaan, veenmol, wilde bijen, vogels onderverdeeld in 1) broedvogels van stedelijk gebied, bossen en parken, 2) broedvogels van moerassen, slootkanten en (natte)bossen, 3) weidevogels en 4) trekvogels en wintergasten. Ten slotte komt ook de flora in dit hoofdstuk aan bod.

\subsection{Zoetwatervissen en brakwatervissen}

Telgebieden voor zoetwatervissen en brakwatervissen worden uitgezet op km-hokniveau waarbinnen 1-3 transecten liggen (Spikmans et al. 2011).

Transecten voor zoetwatervissen worden uitgezet in het landschapstype Zoet water, voor brakwatervissen in het landschapstype Brak water.

\section{Werkwijze}

Elk transect wordt minimaal 2 keer per jaar geïnventariseerd in de periode april tot oktober met een schepnet of op zicht gedurende 1 uur per ronde. Eén inventarisatie vindt plaats in het donker; met name voor het waarnemen van de rivierdonderpad wordt 's nachts geïnventariseerd met een zaklamp. Bemonstering van kleine wateren (poelen) bedraagt minimaal 50 m oeverlengte en maximaal de helft van de oeverlengte.

Alle soorten worden geregistreerd, indien geen soorten worden waargenomen, wordt deze nulwaarneming ook vastgelegd.

Geregistreerd wordt:

Naam waarnemer

Datum

Weersomstandigheden (temperatuur, windsnelheid, neerslag)

Naam van het gebied

Landschapstype

Ligging van het transect

Begin en eindtijd

Soort

Locatie van de waarneming: op puntniveau (Amersfoortcoördinaten)

Type waarneming: $\mathrm{Z}$ - op zicht gedetermineerd, $\mathrm{V}$ - ten minste 1 imago gevangen, $\mathrm{F}$ - gefotografeerd, C - in collectie opgenomen, $\mathrm{S}$ - schepnet

Aantal: liefst exact aantal, bij grote aantallen een schatting

Levensstadium en geslacht (juveniel, subadult, adult man, adult vrouw etc.) 


\subsection{Amfibieën en Reptielen}

\subsubsection{Rugstreeppad}

Telgebieden voor de rugstreeppad worden uitgezet op km-hokniveau waarbinnen 1-4 meetpunten liggen (ANLb-team RAVON 2016). De bemonsteringsinspanning per meetpunt ligt tussen de 15 en 30 minuten.

Meetpunten voor de rugstreeppad worden uitgezet in de landschapstypen: Huizen, erven en overig, Broekbossen, Veenheide, Moeras en vochtige ruigte, Plasdras, Natte tijdelijke natuur, Volkstuinen, en Zoet water.

\section{Werkwijze}

Monitoring dient plaats te vinden in de maanden februari $t / m$ september (daarbuiten worden de waarnemingen op ongeldig gezet) met vier veldbezoeken. Op de meetpunten worden meerdere inventarisatiemethoden gebruikt: na benadering van een water eerst luisteren, daarna (voorzichtig) langs de oever lopen en zichtwaarnemingen doen en vervolgens kan een schepnet gebruikt worden. Alle aanwezige amfibiesoorten worden geregistreerd.

Specifiek voor de rugstreeppad wordt op vaste locaties 1 à 2 minuten gestopt om te luisteren of er kooractiviteit is. De periode hiervoor is half april t/m mei, waarin drie veldbezoeken plaatsvinden. Verwarring met de veenmol is mogelijk. De meeste eisnoeren kunnen in mei op de bodem van het voortplantingswater worden gevonden, maar zijn vaak moeilijk te vinden doordat ze met slib bedekt zijn. In juli zijn de larven te zien. In juli en augustus kunnen de juveniele padden worden waargenomen.

Alle soorten worden geregistreerd; indien geen soorten worden waargenomen, wordt deze nulwaarneming ook vastgelegd.

Geregistreerd wordt:

Naam waarnemer

Datum

Weersomstandigheden (temperatuur, windsnelheid, neerslag)

Naam van het gebied

Landschapstype

Ligging van het meetpunt/km-hok

Begin en eindtijd

Soort

Locatie van de waarneming: liefst op puntniveau (Amersfoortcoördinaten), ten minste op kilometerhok nauwkeurig opschrijven

Type waarneming: $\mathrm{Z}$ - op zicht gedetermineerd, $\mathrm{V}$ - ten minste 1 imago gevangen, F - gefotografeerd, C - in collectie opgenomen, G - gehoor, S - schepnet

Aantal: liefst exact aantal, bij grote aantallen een schatting

Levensstadium en geslacht (ei, larve, subadult, adult man, adult vrouw, etc.)

\subsubsection{Ringslang}

Voor de ringslang worden transecten uitgezet in één habitattype (Smit, G.F.J. \& A. Zuiderwijk, 2003). De lengte van het transect kan variëren en is afhankelijk van het aantal kansrijke plekken. Een lijnvormige route is hoogstens $2000 \mathrm{~m}$ lang. Bij een vlakvormig proefveld, waarbij zigzaggend wordt gelopen en steeds 10 tot $15 \mathrm{~m}$ wordt opgeschoven, zal het oppervlak dat gebiedsdekkend wordt geïnventariseerd 1-2 ha beslaan. De eigenlijke loopafstand is dan ook ongeveer $2000 \mathrm{~m}$. De bemonsteringsinspanning per transect is 2 uur.

Transecten voor de ringslang worden uitgezet in de landschapstypen: Broekbossen, Stadspark, Rietland, Veenmosrietland en veenhooiland, Moeras en vochtige ruigte, Kruidenrijk grasland, Plasdras, Natte tijdelijke natuur, Volkstuinen en Zoet water. 


\section{Werkwijze}

Bij het inventariseren wordt een strook van $5 \mathrm{~m}$ aan weerzijde van het transect gescand gedurende 2 uur. De transecten worden van maart tot en met september gelopen. Vanaf half maart tot mei wordt viermaal gelopen. In de maanden augustus-september wordt het transect driemaal geïnventariseerd. De bezoeken liggen zo veel mogelijk over de twee perioden verspreid. De periode tussen twee bezoeken bedraagt minimaal vijf dagen.

Het weer moet geschikt zijn: niet inventariseren bij een temperatuur van dertig graden Celsius of meer, inventariseren bij droog en zonnig weer, weinig wind. Bij lange perioden met warm weer neemt de behoefte van de dieren om langdurig te zonnen af. De activiteit verschuift dan naar de vroege ochtend en de late middag, op het heetst van de dag schuilen de dieren.

Alle soorten worden geregistreerd; indien geen soorten worden waargenomen, wordt deze nulwaarneming ook vastgelegd.

\section{Geregistreerd wordt:}

Naam waarnemer

Datum

Weersomstandigheden (temperatuur, windsnelheid, neerslag)

Naam van het gebied

Landschapstype

Ligging van het transect

Begin en eindtijd

Soort

Locatie van de waarneming: op puntniveau (Amersfoortcoördinaten)

Type waarneming: Z - op zicht gedetermineerd, F - gefotografeerd, C - in collectie opgenomen Aantal

Levensstadium en geslacht (ei, juveniel, subadult, adult man, adult vrouw, etc.)

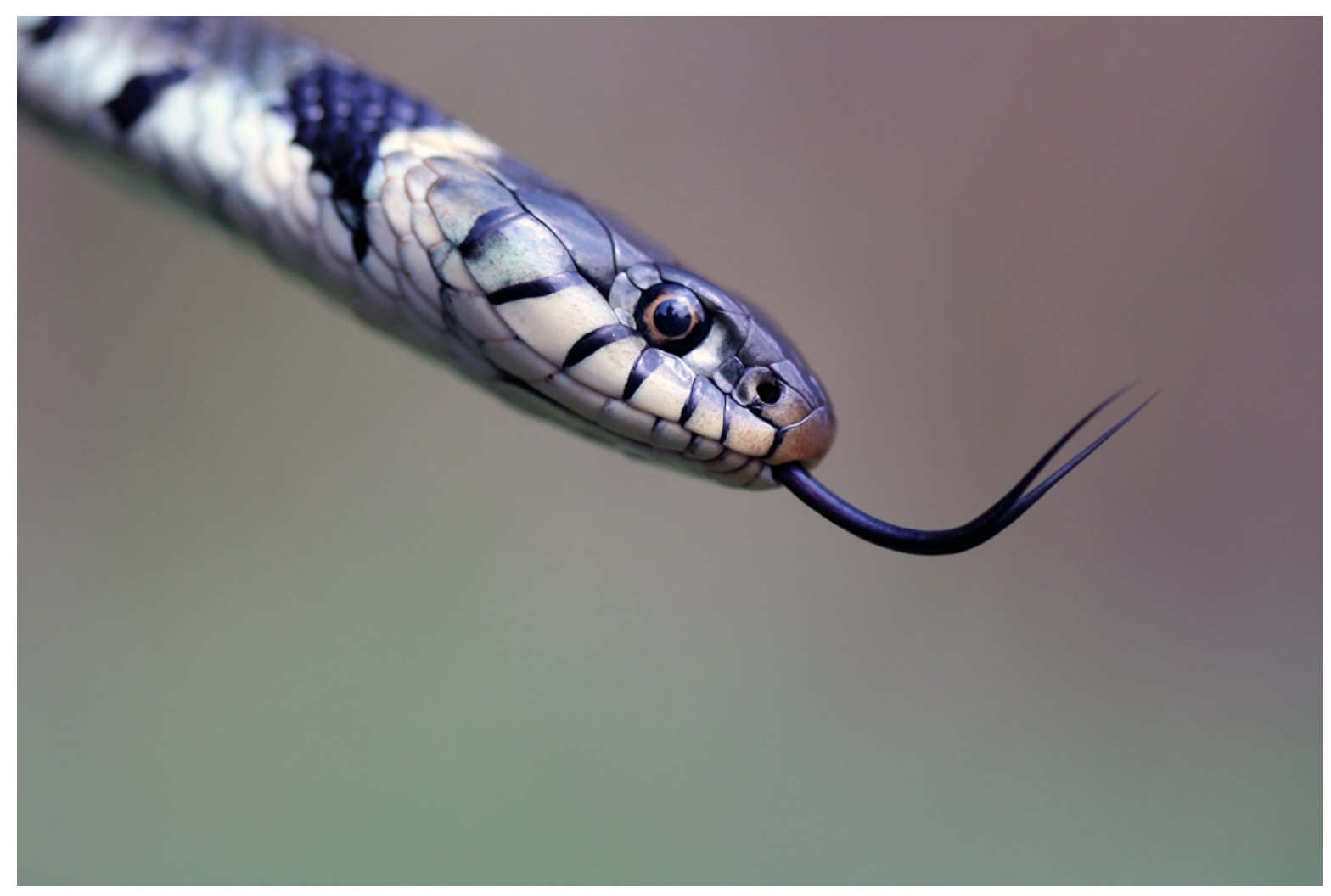

Figuur 2 Detailopname kop van een ringslang (Natrix natrix). Foto: Fabrice Ottburg®). 


\subsection{Vleermuizen}

Transecten voor vleermuizen worden over een lengte van $400 \mathrm{~m}$ uitgezet

(https://www.ndff.nl/overdendff/validatie/protocollen/17-206-meetnet-punt-transecttellingen-

vleermuizen/).

Transecten voor vleermuizen worden uitgezet in de landschapstypen: Huizen, erven en overig, Broekbossen, Stadsparken, Naaldbos, Loofbos en struweel, Kruidenrijk grasland, Agrarisch grasland, Volkstuinen, Brak water, Zoet water.

\section{Werkwijze}

De inventarisatie vindt plaats met bat detectors van april t/m september. De transecten worden 1 keer per maand gelopen met een batdetector. Indien mogelijk worden geluidsopnames gemaakt voor determinatie en validatie.

Het weer moet geschikt zijn: de temperatuur moet hoger zijn dan $7^{\circ} \mathrm{C}$, er dient weinig wind te staan (<3 Bft) en het moet niet regenen (https://www.netwerkgroenebureaus.nl/werken-aankwaliteit/vleermuisprotocol).

De inventarisatie vindt plaats na zonsondergang en voor zonsopgang. Alle soorten worden geregistreerd; indien geen soorten worden waargenomen, wordt deze nulwaarneming ook vastgelegd.

\section{Geregistreerd wordt:}

Naam waarnemer

Datum

Weersomstandigheden (temperatuur, windsnelheid, neerslag)

Naam van het gebied

Landschapstype

Ligging van het transect

Zoektijd

Soort

Locatie van de waarneming: liefst op puntniveau (Amersfoortcoördinaten)

Type waarneming: Z - op gehoor gedetermineerd, F - gefotografeerd, C - opname sonogram beschikbaar

Aantal

Geslacht 


\subsection{Overige zoogdieren}

Voor de Noordse woelmuis en waterspitsmuis worden standaard $100 \mathrm{~m}$ transecten uitgezet (Bij12 2017; https://www.ndff.nl/wp-content/uploads/2015/12/17.001-Onderzoek-naar-de-verspreidingvan-noordse-woelmuis-en-waterspitsmuis-met-behulp-van-inloopvallen.pdf). Voor bunzing en wezel worden cameravallen geplaatst in een grid van $5 * 5 \mathrm{~km}$ op kansrijke locaties (La Haye et al. 2017). Transecten voor overige zoogdieren worden uitgezet in de landschapstypen: Huizen, erven en overig, Broekbossen, Stadsparken, Loofbos en struweel, Rietland, Veenmosrietland en veenhooiland, Moeras en vochtige ruigte, Droge rietlanden en ruigte, Kruidenrijk grasland, Wegberm, Spoorberm, Tijdelijke droge natuur, Tijdelijke natte natuur, Volkstuinen, Brak water, Zoet water.

\section{Werkwijze waterspitsmuis en Noordse woelmuis}

De inventarisatie van waterspitsmuis en Noordse woelmuis vindt plaats met inloopvallen (life-traps) van augustus t/m oktober. Transecten zijn 100m lang met een raai van 2 vallen om de $10 \mathrm{~m}$. Voordat de vallen worden scherp gezet om te vangen, wordt 2-4 dagen 'geprebait'.

De inventarisatie vindt plaats gedurende 2 vangnachten voor de Noordse woelmuis en 3 nachten voor de waterspitsmuis (resp. 4 en 6 controles).

Alle soorten worden geregistreerd met minimaal 1 foto per soort als bewijs; indien geen soorten worden waargenomen, wordt deze nulwaarneming ook vastgelegd.

\section{Geregistreerd wordt:}

Naam waarnemer

Datum

Weersomstandigheden (temperatuur, windsnelheid, neerslag)

Naam van het gebied

Landschapstype

Ligging van het transect

Valnummer

Vangperiode: begin- en eindtijdstip

Soort

Locatie van de waarneming: liefst op puntniveau (Amersfoortcoördinaten)

Type waarneming: Z - op zicht gedetermineerd, F - gefotografeerd

Aantal

Leeftijd geslacht

\section{Werkwijze bunzing \& wezel}

De inventarisatie vindt plaats met 4-6 weken cameravallen in een $5 * 5 \mathrm{~km}$-grid. De lens van de camera moet zich tussen de 20 en $25 \mathrm{~cm}$ boven het maaiveld bevinden, waarbij de camera parallel aan de grond recht naar voren richting het blikje sardines kijkt. Op een afstand tussen de 150 en $200 \mathrm{~cm}$ voor de camera wordt een blikje sardines vastgeschroefd of gespijkerd aan een naburige boom of ander vast punt. De onderkant van het blikje sardines dient precies op $15 \mathrm{~cm}$ boven het maaiveld te hangen. $\mathrm{Er}$ worden tussentijds geen geheugenkaartjes vervangen, ditzelfde geldt voor het blikje.

Alle soorten die worden gefotografeerd, worden op naam gebracht en geregistreerd; indien geen soorten worden waargenomen, wordt deze nulwaarneming ook vastgelegd.

Geregistreerd wordt:

Naam waarnemer

Datum

Weersomstandigheden (temperatuur, windsnelheid, neerslag)

Naam van het gebied

Landschapstype

Ligging van het transect

Valnummer

Vangperiode: begin- en eindtijdstip

Soort

Locatie van de waarneming: liefst op puntniveau (Amersfoortcoördinaten)

Type waarneming: Z - op zicht gedetermineerd, F - gefotografeerd

Aantal

Leeftijd geslacht 


\subsection{Dagvlinders}

Voor het monitoren van dagvlinders worden transecten uitgezet van maximaal $1 \mathrm{~km}$ lengte, verdeeld in secties van 50 m (Van Swaay et al. 2011). De secties dienen een homogene vegetatiestructuur te hebben.

Transecten voor dagvlinders worden uitgezet in de landschapstypen: Huizen, erven en overig, Broekbossen, Stadsparken, Naaldbos, Loofbos en struweel, Veenmosrietland en veenhooiland, Moeras en vochtige ruigte, Droge rietlanden en ruigte, Kruidenrijk grasland, Wegberm, Spoorberm, Tijdelijke droge natuur, Tijdelijke natte natuur, Volkstuinen.

\section{Werkwijze}

De inventarisatie op zicht vindt plaats vanaf april t/m september. Een transect wordt minimaal 1 keer/week gelopen.

De inventarisatie vindt plaats tussen 10:00 en 17:00 uur,.

Het weer moet geschikt zijn: de bedekking door wolken moet bij een temperatuur tussen 13 en $17^{\circ} \mathrm{C}$ $50 \%$ of minder zijn, bij $17{ }^{\circ} \mathrm{C}$ of meer kan ook geteld worden bij meer dan $50 \%$ bewolking. De windkracht mag niet hoger zijn dan 5 Beaufort en tijdens de zoekperiode mag er geen neerslag zijn. Soorten worden geteld door met een rustige wandelpas alle vlinders (alleen imago's) te tellen op een afstand van 2,5 links en rechts van de waarnemer, tot een hoogte van $5 \mathrm{~m}$ boven en $5 \mathrm{~m}$ voor de waarnemer. Alle soorten worden geregistreerd; indien geen soorten worden waargenomen, wordt deze nulwaarneming ook vastgelegd.

\section{Geregistreerd wordt:}

Naam waarnemer

Datum

Weersomstandigheden (temperatuur, windsnelheid, neerslag)

Naam van het gebied

Landschapstype

Ligging van het transect

Sectienummer; begin- en eindcoördinaat (Amersfoortcoördinaten)

Begin- en eindtijd; elke keer dat een transect wordt geteld, is een nieuw bezoek met een begin- en eindtijd

Soort

Type waarneming: $Z$ - alle imago's op zicht gedetermineerd, $\mathrm{V}$ - ten minste 1 imago gevangen, $\mathrm{F}$ - gefotografeerd, $\mathrm{C}$ - in collectie opgenomen

Aantal: liefst exact aantal, bij grote aantallen een schatting

Bijzonderheden beheer: indien gekapt, gemaaid etc.

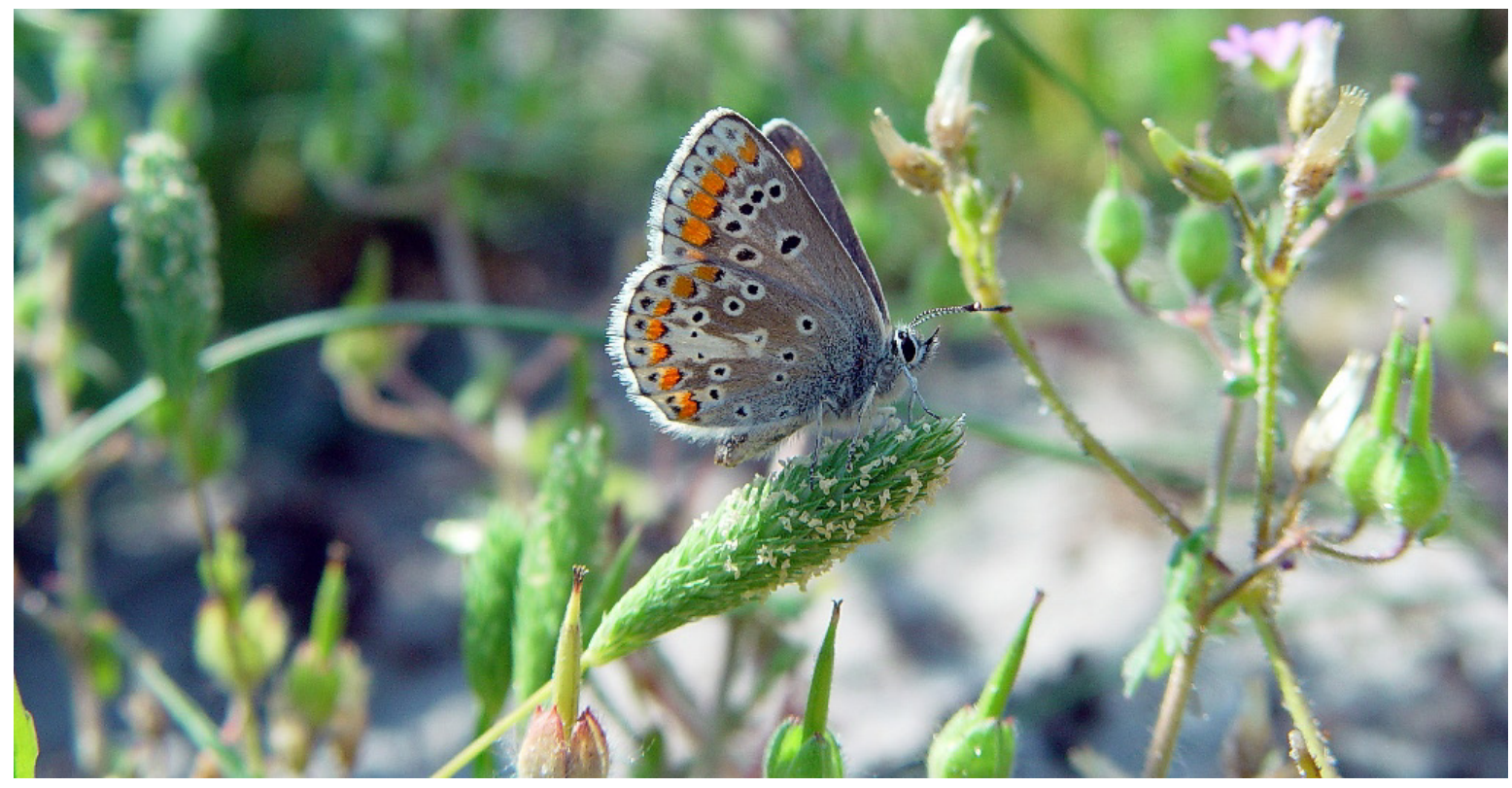

Figuur 3 Icarusblauwtje (Polyommatus icarus). Foto: Fabrice Ottburg@). 


\subsection{Glassnijder}

Voor het monitoren van libellen wordt voor de geselecteerde landschapstypen een standaardtransect gelopen van 100 m (Bouwman \& Kalkman 2004; Van Swaay et al. 2011). Het transect waarin geteld wordt, bevat $2 \mathrm{~m}$ oever en $5 \mathrm{~m}$ water.

Transecten worden uitgezet in de landschapstypen: Rietland, Veenmosrietland \& hooiland, moeras en vochtige ruigte, plasdras, zoet water.

\section{Werkwijze}

De inventarisatie op zicht vindt plaats binnen de vliegtijd van de Glassnijder (april t/m juni). Een transect wordt minimaal 3 keer gelopen, verspreid over de vliegtijd met een tijd tussen de rondes van minimaal 2 dagen.

De inventarisatie vindt plaats tussen 11:00 en 16:00 uur, bij temperaturen boven de $22^{\circ} \mathrm{C}$, tussen 10:30 en 16:30 uur.

Het weer moet geschikt zijn: de bedekking door wolken moet minder zijn dan $75 \%$, de windkracht mag niet hoger zijn dan 5 Beaufort, de temperatuur mag niet lager zijn dan $17^{\circ} \mathrm{C}$ en tijdens de zoekperiode mag er geen neerslag zijn.

De zoektijd dient minimaal één uur te bedragen.

Alle soorten worden geregistreerd; indien geen soorten worden waargenomen, wordt deze nulwaarneming ook vastgelegd.

Geregistreerd wordt:

Naam waarnemer

Datum

Weersomstandigheden (temperatuur, windsnelheid, neerslag)

Naam van het gebied

Landschapstype

Ligging van het transect

Begin- en eindtijd

Soort

Locatie van de waarneming: liefst op puntniveau (Amersfoortcoördinaten), ten minste op kilometerhok nauwkeurig opschrijven

Type waarneming: $Z$ - alle imago's op zicht gedetermineerd, $V$ - ten minste 1 imago gevangen, $\mathrm{F}$ - gefotografeerd, $\mathrm{C}$ - in collectie opgenomen

Aantal: liefst exact aantal, bij grote aantallen een schatting

Levensstadium en geslacht (ei, larve, exuviae, tandem, man, vrouw, imago onbepaald etc.) 


\subsection{Moerassprinkhaan en veenmol}

Voor het monitoren van sprinkhanen wordt voor de geselecteerde landschapstypen een standaard transect gelopen van $100 \mathrm{~m}$.

Transecten worden voor de veenmol uitgezet in de landschapstypen: Huizen, erven en overig, Veenheide, Veenmosrietland en veenhooiland, Moeras en vochtige ruigte, Kruidenrijk grasland, Agrarisch grasland, Volkstuinen, Bouwland.

Transecten worden voor de moerassprinkhaan uitgezet in de landschapstypen: Veenheide, Veenmosrietland en veenhooiland, Moeras en vochtige ruigte, Kruidenrijk grasland, Tijdelijke natte natuur, Zoet water.

\section{Werkwijze}

De inventarisatie van de veenmol vindt plaats op het gehoor in het voorjaar (april t/m mei), wanneer de mannetjes zingen. Daarnaast kunnen potvallen worden ingegraven om dieren te vangen, of planken en stenen worden opgetild. De inventarisatie van de moerassprinkhaan vindt plaats op zicht en gehoor vanaf eind juli $t / m$ september.

De inventarisatie vindt voor de veenmol plaats vanaf de schemering. De inventarisatie voor de moerassprinkhaan vindt overdag plaats.

Het weer moet geschikt zijn: de windkracht mag niet hoger zijn dan 4 Beaufort, de temperatuur mag niet lager zijn dan $12^{\circ} \mathrm{C}$ voor de veenmol en $17^{\circ} \mathrm{C}$ voor de moerassprinkhaan, tijdens de zoekperiode mag er geen neerslag zijn.

De zoektijd dient minimaal één uur te bedragen.

Alle soorten sprinkhanen en krekels worden geregistreerd; indien geen soorten worden waargenomen, wordt deze nulwaarneming ook vastgelegd.

\section{Geregistreerd wordt:}

Naam waarnemer

Datum

Weersomstandigheden (temperatuur, windsnelheid, neerslag)

Naam van het gebied

Landschapstype

Ligging van het transect

Zoektijd

Soort

Locatie van de waarneming: liefst op puntniveau (Amersfoortcoördinaten)

Type waarneming: $Z$ - op zicht gedetermineerd, V - ten minste 1 imago gevangen, F - gefotografeerd, G - Geluid opgenomen, C - in collectie opgenomen

Aantal: liefst exact aantal, bij grote aantallen een schatting Levensstadium en geslacht (man, vrouw, imago onbepaald etc.)

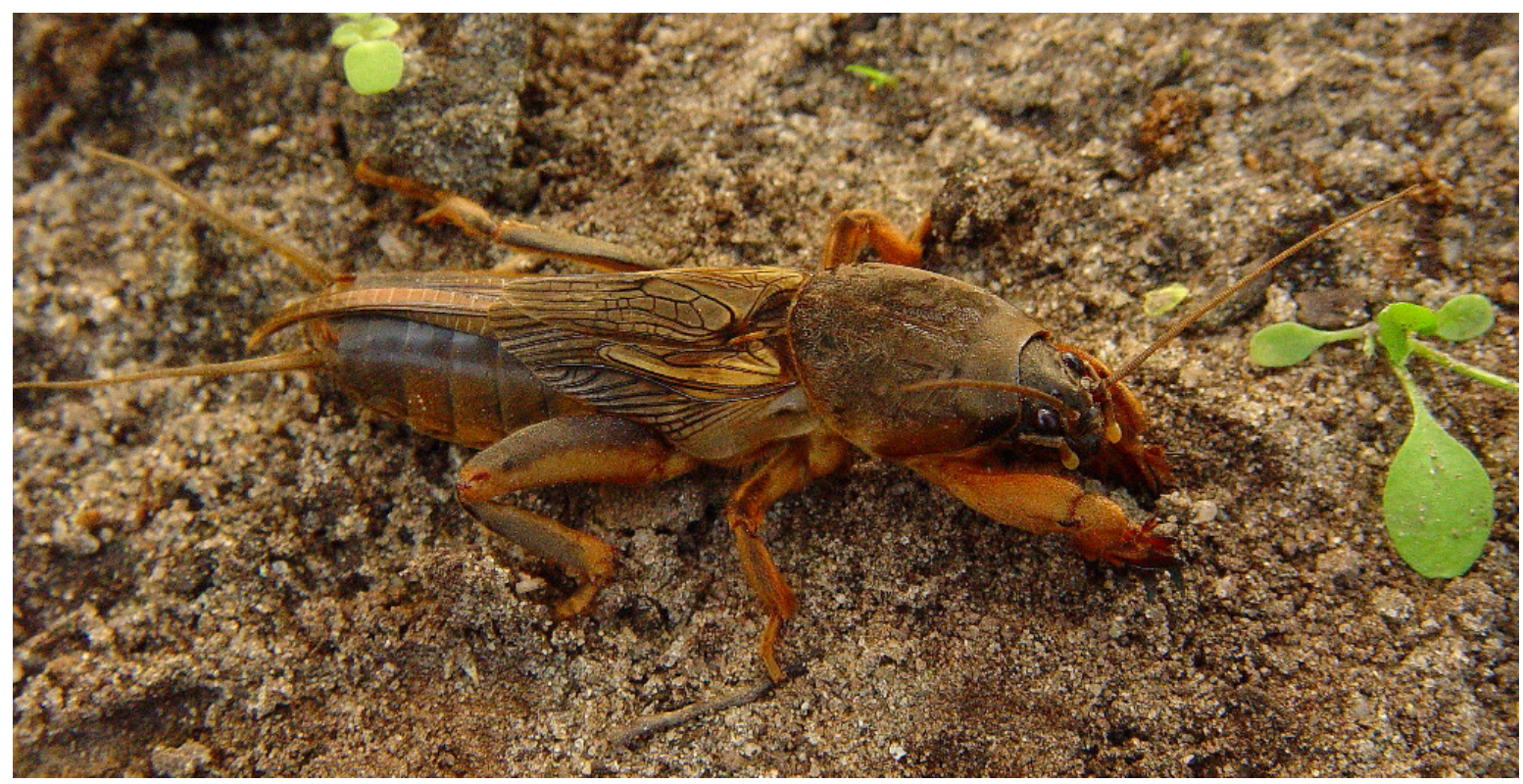

Figuur 4 Veenmol (Gryllotalpa gryllotalpa). Foto: Fabrice Ottburg®). 


\subsection{Wilde bijen}

Voor het monitoren van wilde bijen wordt voor de geselecteerde landschapstypen een standaard transect gelopen van 100 m (Reemer, 2016).

Transecten worden uitgezet in de landschapstypen: Huizen, erven en overig, Stadspark, Loofbos \& struweel, Rietland, Veenmosrietland en veenhooiland, Moeras en vochtige ruigte, Droge rietlanden en ruigte, Kruidenrijk grasland, Wegberm, Spoorberm, Plantsoen, Tijdelijke droge natuur, Tijdelijke natte natuur, Volkstuinen, Brak water, Zoet water.

\section{Werkwijze}

De inventarisatie vindt plaats op het zicht gedurende 3 rondes: in het vroege voorjaar (april), late voorjaar (mei) en in de zomer (juli).

De inventarisatie vindt plaats tussen 11:00 en 16:00 uur.

Het weer moet geschikt zijn: de bedekking door wolken moet minder zijn dan $75 \%$, de windkracht mag niet hoger zijn dan 4 Beaufort, de temperatuur mag niet lager zijn dan $12^{\circ} \mathrm{C}$ in het vroege voorjaar en $17^{\circ} \mathrm{C}$ in de overige twee perioden, tijdens de zoekperiode mag er geen neerslag zijn. De zoektijd dient minimaal één uur te bedragen.

Alle soorten worden geregistreerd; indien geen soorten worden waargenomen, wordt deze nulwaarneming ook vastgelegd.

\section{Geregistreerd wordt:}

Naam waarnemer

Datum

Weersomstandigheden (temperatuur, windsnelheid, neerslag)

Naam van het gebied

Landschapstype

Ligging van het transect

Zoektijd

Soort

Locatie van de waarneming liefst op puntniveau (Amersfoortcoördinaten)

Type waarneming: $Z$ - op zicht gedetermineerd, $\mathrm{V}$ - ten minste 1 imago gevangen, $\mathrm{F}$ - gefotografeerd, $\mathrm{C}$ - in collectie opgenomen

Aantal: liefst exact aantal, bij grote aantallen een schatting Levensstadium en geslacht (man, vrouw, imago onbepaald etc.)

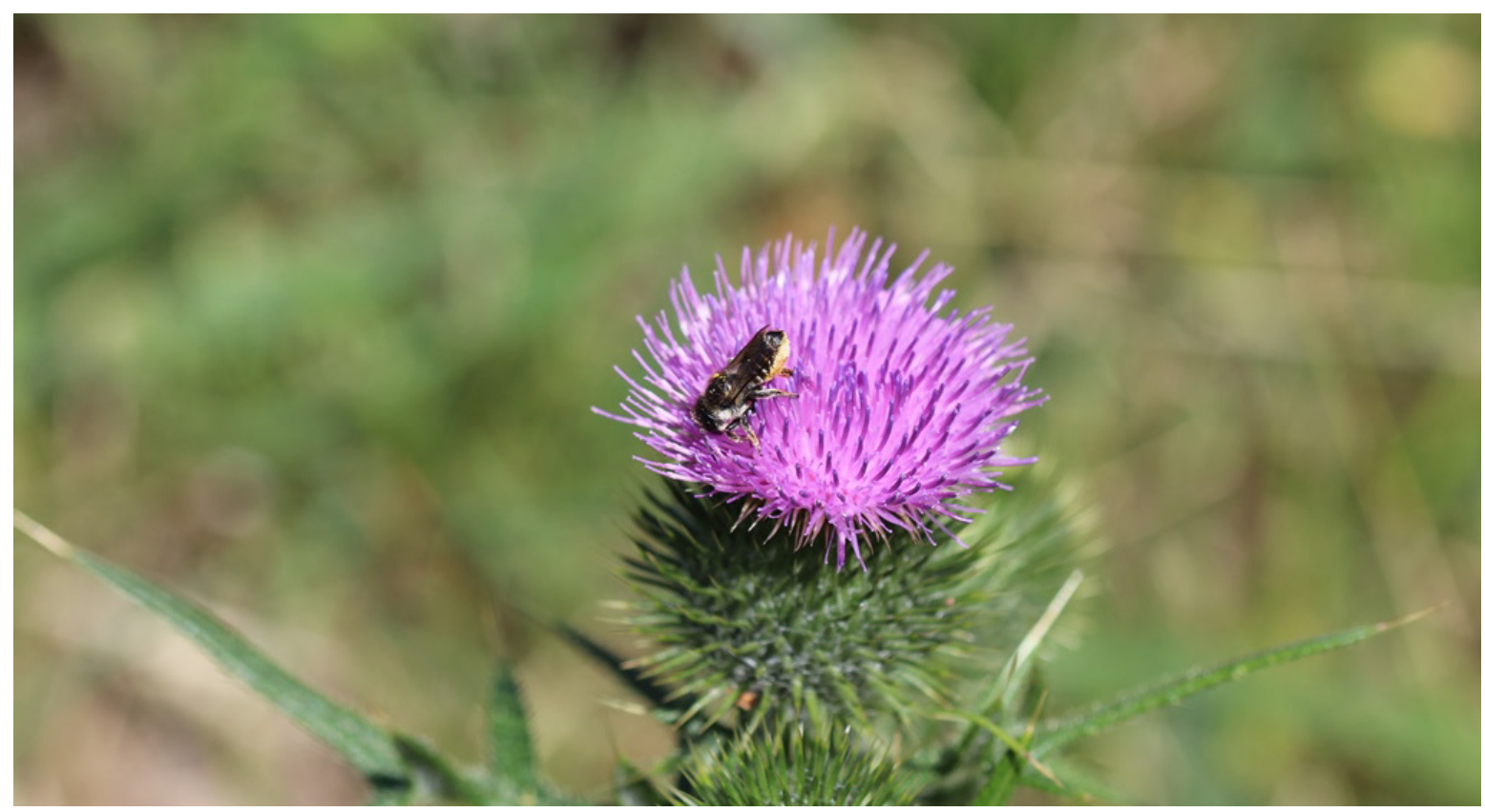

Figur 5 Tuinbladsnijder (Megachile centuncularis). Foto: Fabrice Ottburg (C). 


\section{$3.9 \quad$ Vogels}

\subsubsection{Broedvogels van stedelijk gebied, bossen en parken}

Voor de broedvogels van stedelijk gebied worden transecten uitgezet van $1600 \mathrm{~m}$ lengte (Van Turnhout \& Van Diek, 2007).

Transecten worden uitgezet in de landschapstypen: Huizen, erven en overig, Stadspark, Loofbos \& struweel, Droge rietlanden en ruigte, Tijdelijke droge natuur, Tijdelijke natte natuur, Volkstuinen.

\section{Werkwijze}

De inventarisatie vindt plaats gedurende 3 rondes (in de periode 1-30 april, 15 mei-15 juni (beide keren in de vroege ochtend) en 15 juni-15 juli (in de avond).

Het weer moet geschikt zijn: niet tellen bij harde wind en/of regen.

Op het transect wordt op 8 vaste telpunten geteld, met een onderlinge afstand van minimaal $200 \mathrm{~m}$.

Er wordt exact gedurende 5 minuten geteld.

Overvliegende vogels worden niet geregistreerd (m.u.v. gierzwaluwen).

Alle soorten worden geregistreerd; indien geen soorten worden waargenomen, wordt deze nulwaarneming ook vastgelegd.

Geregistreerd wordt:

Naam waarnemer

Datum

Tijd begin-eind

Weersomstandigheden (temperatuur, windsnelheid, neerslag)

Naam van het gebied

Landschapstype

Ligging van het transect

Soort

Locatie van de waarneming op puntniveau (Amersfoortcoördinaten)

Type waarneming: Z - op zicht, G - op gehoor, F - gefotografeerd

Aantal: liefst exact aantal, bij grote aantallen een schatting

Geslacht en leeftijd (man, vrouw, juveniel, subadult, adult) 


\subsubsection{Broedvogels van moerassen, slootkanten en (natte) bossen}

Voor de broedvogels van moerassen, slootkanten en natte bossen worden telgebieden van 10 tot 30 ha vastgelegd (Vergeer et al. 2016).

Telgebieden worden uitgezet in de landschapstypen: Broekbossen, Naaldbos, Loofbos \& struweel, Veenheide Rietland, Veenmosrietland en veenhooiland, Moeras en vochtige ruigte, Brak water, Zoet water.

\section{Werkwijze}

De vlakdekkende inventarisatie vindt plaats gedurende 12 rondes in de periode februari $\mathrm{t} / \mathrm{m}$ juni, met de focus op half april-juni. Bezoekrondes vinden 7 keer plaats in de schemering bij zonsopgang, 2 keer na zonsondergang, 2 keer laat in de ochtend en 1 keer in de vroege avond.

Overvliegende vogels worden niet geregistreerd.

Alle soorten worden geregistreerd; indien geen soorten worden waargenomen, wordt deze nulwaarneming ook vastgelegd.

\section{Geregistreerd wordt:}

Naam waarnemer

Datum

Weersomstandigheden (temperatuur, windsnelheid, neerslag)

Naam van het gebied

Landschapstype

Ligging van de gevolgde route

Soort

Locatie van de waarneming op puntniveau (Amersfoortcoördinaten)

Type waarneming: Z - op zicht, G - op gehoor, F - gefotografeerd

Aantal: liefst exact aantal, bij grote aantallen een schatting

Geslacht en leeftijd (man, vrouw, juveniel, subadult, adult)

Broedcode

\subsubsection{Weidevogels}

Voor de broedvogels van agrarisch gebied worden telgebieden van 30 tot 250 ha vastgelegd (Vergeer et al. 2016).

Telgebieden worden uitgezet in de landschapstypen: Kruidenrijk grasland, Plasdras, Agrarisch grasland, Bouwland.

\section{Werkwijze}

De vlakdekkende inventarisatie vindt plaats gedurende 7 rondes in de periode maart t/m juli. Bezoekrondes vinden 4 keer plaats in de schemering bij zonsopgang, 1 keer na zonsondergang en 2 keer in de late ochtend.

Overvliegende vogels worden niet geregistreerd.

Alle soorten worden geregistreerd; indien geen soorten worden waargenomen, wordt deze nulwaarneming ook vastgelegd.

Geregistreerd wordt:

Naam waarnemer

Datum

Weersomstandigheden (temperatuur, windsnelheid, neerslag)

Naam van het gebied

Landschapstype

Ligging van de gevolgde route

Soort

Locatie van de waarneming op puntniveau (Amersfoortcoördinaten)

Type waarneming: Z - op zicht, G - op gehoor, F - gefotografeerd

Aantal: liefst exact aantal, bij grote aantallen een schatting

Geslacht en leeftijd (man, vrouw, juveniel, subadult, adult)

Broedcode 


\subsubsection{Trekvogels en wintergasten}

Voor de telling van trekvogels en wintergasten worden transecten met telpunten uitgelegd van minimaal $5 \mathrm{~km}$ lengte (Van Manen \& De Jong 2016).

Transecten met telpunten worden uitgezet in de landschapstypen: Huizen, erven en overig, Broekbossen, Stadspark, Naaldbos, Loofbos \& struweel, Veenheide, Rietland, Veenmosrietland en veenhooiland, Moeras en vochtige ruigte, Kruidenrijk grasland, Plasdras, Agrarisch grasland, Tijdelijke droge natuur, Tijdelijke natte natuur, Volkstuinen, Brak water, Zoet water.

\section{Werkwijze}

De inventarisatie vindt plaats gedurende 1 ronde in de periode 15 december $t / m 1$ januari. Er wordt geteld tussen 9:15 en 16:00 uur.

Op het transect wordt op 20 telpunten geteld gedurende 5 minuten. In gesloten landschappen is de afstand tussen telpunten minimaal $250 \mathrm{~m}$, in open landschap minimaal $500 \mathrm{~m}$.

Overvliegende vogels worden ook geregistreerd.

Alle soorten worden geregistreerd; indien geen soorten worden waargenomen, wordt deze nulwaarneming ook vastgelegd.

\section{Geregistreerd wordt:}

Naam waarnemer

Datum

Weersomstandigheden (temperatuur, windsnelheid, neerslag)

Naam van het gebied

Landschapstype

Ligging van het transect

Locatie van de waarneming op puntniveau (Amersfoortcoördinaten)

Soort

Locatie van de waarneming op puntniveau (Amersfoortcoördinaten)

Type waarneming: $Z$ - op zicht, G - op gehoor, F - gefotografeerd

Aantal: liefst exact aantal, bij grote aantallen een schatting

Geslacht en leeftijd (man, vrouw, juveniel, subadult, adult)

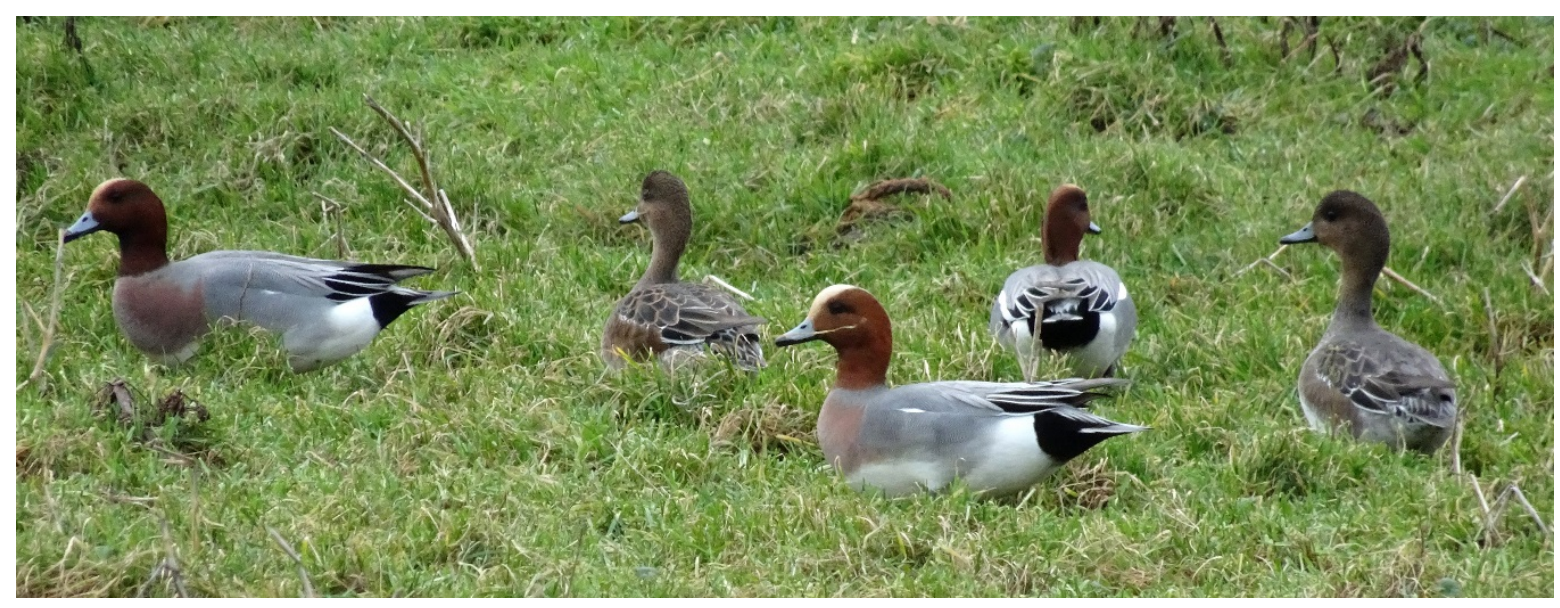

Figuur 6 Smienten (Anas penelope). Foto Fabrice Ottburg $($. 


\subsection{Flora}

Voor het monitoren van planten worden permanente kwadraten ( $P Q$ 's) uitgezet in diverse landschapstypen (Centraal Bureau voor de Statistiek (2000, herziene versie 2003)).

PQ's worden uitgezet in de landschapstypen: Huizen, erven en overig, Stadspark, Loofbos \& struweel, Veenheide, Rietland, Veenmosrietland en veenhooiland, Moeras en vochtige ruigte, Droge rietlanden en ruigte, Kruidenrijk grasland, Plasdras, Wegberm, Agrarisch grasland, Spoorberm, Plantsoen, Tijdelijke droge natuur, Tijdelijke natte natuur, Volkstuinen, Bouwland, Brak water, Zoet water. Voor muurplanten worden daarnaast transecten uitgelegd van $300 \mathrm{~m}$ lengte langs muren en kades (Sparrius et al. 2015). Dit gebeurt uitsluitend voor het landschapstype Huizen, erven en overig.

\section{Werkwijze $P Q$ 's}

PQ's worden uitgezet binnen de landschapstypen, waarbij de vegetatie homogeen moet zijn en randeffecten zo veel mogelijk worden uitgesloten.

Een $\mathrm{PQ}$ is $25 \mathrm{~m}^{2}$ groot. Uitzondering hierop vormen houtwallen en hagen $50 \mathrm{~m}^{2}$, slootkanten en natuurvriendelijke oevers $50 \mathrm{~m}^{2}$, bos $200 \mathrm{~m}^{2}$ en struweel $100 \mathrm{~m}^{2}$.

Kartering van PQ's vindt iedere 4 jaar plaats in een zodanig schema dat elk jaar een kwart van de PQ's aan de beurt komt. Hierbij is het van belang dat er elk jaar een goede ruimtelijk spreiding en een spreiding over de landschapstypen van de op te nemen PQ's is.

De vegetatie wordt gekarteerd met de methode van Braun-Blanquet.

Alle soorten hogere planten die in de PQ's aanwezig zijn, worden genoteerd, evenals van elke soort de mate van aanwezigheid (uitgedrukt in aantal exemplaren en/of bedekking). Facultatief mogen ook mossen worden opgenomen.

\section{Werkwijze muurplanten}

De inventarisatie vindt plaats op het zicht in de periode mei-september.

De inventarisatie vindt minimaal eenmaal per 5 jaar plaats.

Alle soorten worden geregistreerd die op de muur groeien.

Aantallen worden exact geteld indien mogelijk en anders geschat.

Geregistreerd wordt voor de $P Q$ 's:

Naam waarnemer

Datum

Naam van het gebied

Ligging van het PQ

Landschapstype

Begroeiingstype (IPI)

Oppervlak PQ

Locatie van de waarneming op puntniveau (Amersfoortcoördinaten)

Bedekking totaal, boomlaag, struiklaag, kruidlaag, moslaag

Soort

Laag waarin de soort voorkomt

Bedekking

Bijzonderheden in het beheer (maaien, brand, kap etc.)

Geregistreerd wordt voor muurplanten:

Naam waarnemer

Datum

Naam van het gebied

Landschapstype

Ligging van het transect (Amersfoortcoördinaten)

Zoektijd

Soort

Type waarneming: Z - op zicht gedetermineerd, F - gefotografeerd

Aantal: liefst exact aantal, bij grote aantallen een schatting 


\section{$4 \quad$ Eisen aan de waarnemer}

Van waarnemers moet worden verwacht dat ze beschikken over een adequate kennis m.b.t. het waarnemen en determineren van de soorten die ze monitoren. Dit geldt zowel voor bureaus die worden ingehuurd als voor vrijwilligers. Training/opleiding is hierbij van belang (zie H 7.2).

Transecten en telgebieden worden vastgelegd en mogen niet op eigen houtje door de waarnemer worden verlegd of uitgebreid. Wanneer een (deel van een) transect vervalt of een waarnemer niet in staat is om zijn telrondes te doen, dient contact opgenomen te worden met de coördinator/stadsecoloog.

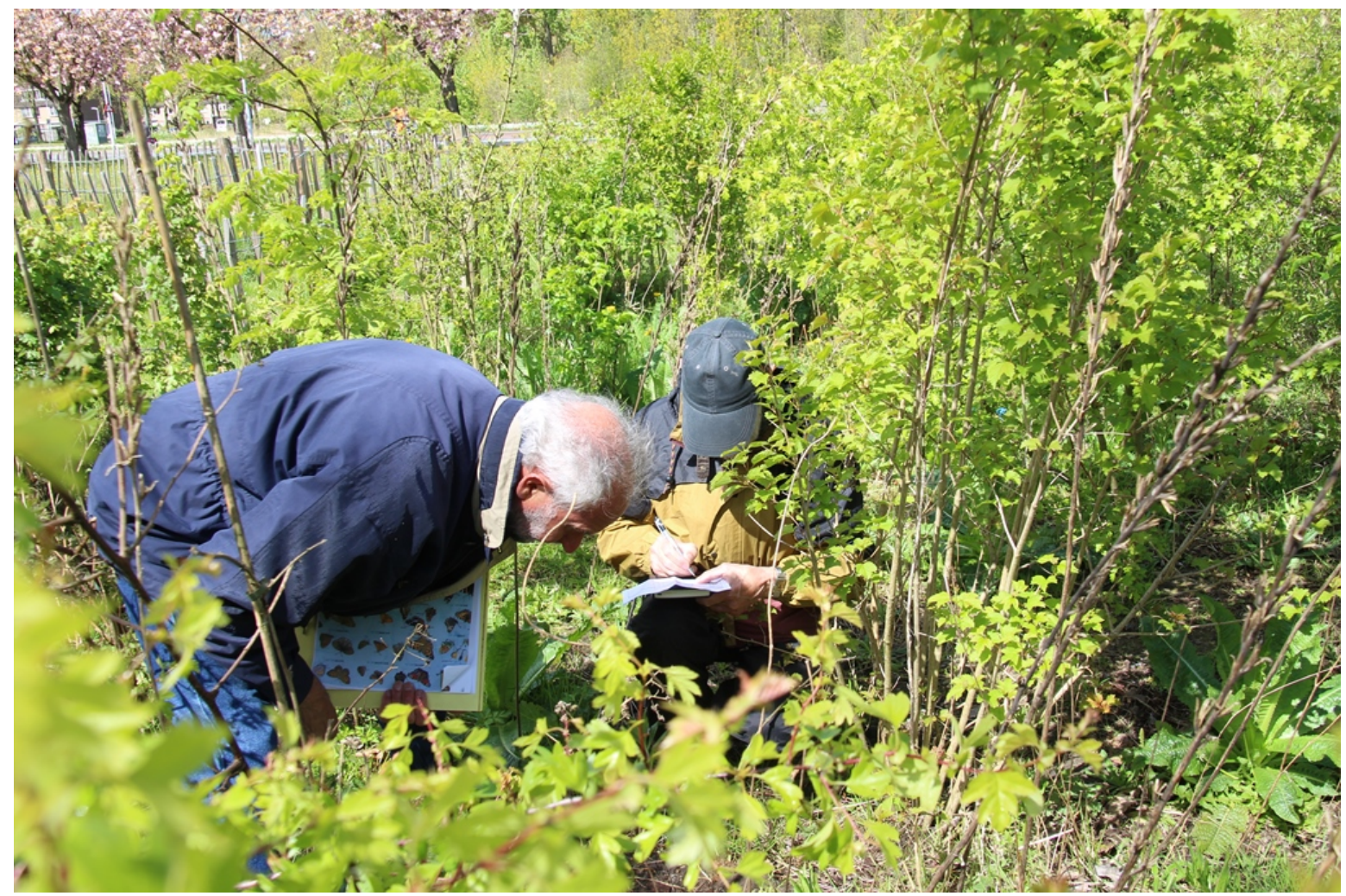

Figuur $7 \quad$ Twee vrijwilligers die de biodiversiteit monitoren in Tiny Forest Zaanstad. Foto: Fabrice Ottburg@. 


\section{$5 \quad$ Dataopslag}

Voor het opslaan van data kan de gemeente Zaanstad kiezen voor een eigen databank of aansluiten bij de bestaande onlinedatabank van de Nationale databank flora en fauna (NDFF). Aanbevolen wordt om te kiezen voor de opslag van data in de NDFF, omdat dan alle losse waarnemingen van vrijwilligers, natuuronderzoeken uitgevoerd in opdracht van de gemeente, data vanuit lopende meetnetten door derden (Provincie, terreinbeherende organisaties (TBO's), soortenorganisaties (de zogeheten PGO's ofwel de Particuliere Gegevensbeherende Organisaties) etc.) en waarnemingen uit de monitoring zoals beschreven in $\mathrm{H} 3$ beschikbaar zijn. Hierdoor wordt de databeschikbaarheid voor de gemeente verveelvoudigd t.o.v. de eigen data en is aansluiting met andere partijen, zoals Staatsbosbeheer, binnen de gemeente geborgd. Daarnaast kunnen data eenvoudig worden geladen en geraadpleegd in de databank van de NDFF.

Voordeel van opslag van data m.b.t. de biodiversiteit van de gemeente is dat altijd actuele data beschikbaar zijn over de biodiversiteit van de gemeente. Deze data geven ruimtelijk inzicht in de beschikbaarheid van natuurgegevens. Hierdoor wordt het voor de gemeente mogelijk om een goed inzicht te verkrijgen in de 'onderzoeksvolledigheid' binnen de gemeente, zijn verspreidingsdata beschikbaar en kan een inschatting worden gemaakt van benodigd natuuronderzoek bij ruimtelijke ontwikkelingen binnen de gemeente. Daarnaast kan inzicht worden verkregen in het benodigde beheer en beleid t.a.v. het beheer van soorten binnen de onderscheiden landschapstypen. Denk hierbij aan beheersingrepen in het openbaar groen, zoals maaibeheer, waardoor de aanwezigheid van soorten kan worden bevorderd door een juiste wijze en tijdstip van uitvoeren, of juist worden belemmerd wanneer de uitvoering te wensen overlaat.

\subsection{Dataopslag in het veld}

Opslag van data in het veld kan met veldformulieren, met een dictafoon of digitaal. Indien gekozen wordt voor veldformulieren of een dictafoon, dienen de data naderhand gedigitaliseerd te worden in het juiste format. Digitale invoer is ook mogelijk, waardoor de data direct in de databank kunnen worden ingevoerd. Hiervoor zijn al apps beschikbaar voor iPhone en Android (NDFF-invoer en ObsMapp; https://www.ndff.nl/overdendff/data/). Vegetatieopnames kunnen ook worden ingevoerd met Turboveg, waarbij validatie plaatsvindt tijdens de invoer. Broedvogelkarteringen kunnen worden ingevoerd met Avimap. De stadsecoloog of coördinatoren van de diverse betrokkenen bij het meetnet van de gemeente dienen toezicht te houden op de kwaliteit van de aangeleverde data door waarnemers.

\subsection{Het opzetten van een database}

Waarnemingen dienen te worden ingevoerd in een dbase. Hieraan zijn eisen verbonden, om zo een eenduidige in- en uitvoer te borgen. In eerste instantie kunnen data worden ingevoerd in een "Stand alone" database voor de gemeente Zaanstad. Hier zitten records in van losse waarnemingen, natuuronderzoeken uitgevoerd in opdracht van de gemeente en waarnemingen uit de monitoring zoals beschreven in H3. Data-invoer kan gedaan worden door de waarnemers in een voorgeschreven format.

Waarnemingen worden ingevoerd in de velden zoals beschreven zoals beschreven in $\mathrm{H} 3$.

Specifieke eisen zijn:

Elke waarneming wordt ingevoerd op een aparte regel. Een waarneming van 5 mannen en 2 wijfjes wordt op twee verschillende regels ingevoerd.

De datum wordt ingevoerd in drie verschillende velden: jaar, maand, dag (yyyy, mm, dd). De $x$ - en y-coördinaat (Rijksdriehoek/Amersfoort coördinaten) worden ingevoerd in verschillende velden. Geef nulwaarnemingen nooit aan door een nul in het veld 'aantal' te zetten, maar geef ze aan 
in een apart veld "nulwaarneming" met een ' $\mathrm{N}$ '. Dit is van belang, omdat sommige database-

programma's automatisch een nul neer zetten als een veld niet wordt ingevuld. Hierdoor is niet altijd

te zien of een waarnemer het veld niet heeft ingevuld of dat hij bewust een nulwaarneming doorgeeft.

Validatie

Waarnemingen moeten worden gevalideerd. Validatie van waarnemingen dient gedaan te worden door experts op basis van kennisregels. Het verdient aanbeveling om te controleren of waarnemingen van een bepaalde soort zijn gedaan binnen het huidige verspreidingsgebied, of de waargenomen aantallen realistisch zijn en of de waarneming valt binnen de periode waarin de soort actief is (vliegtijd, bloeiperiode etc.). Indien waarnemingen niet aannemelijk lijken, dient de waarnemer bewijs te kunnen overleggen, bijvoorbeeld in de vorm van foto's, om opname in de databank te rechtvaardigen.

\subsection{Aandacht van dataopslag bij gemeenteprojecten waarvoor natuurtoetsen zijn uitgevoerd}

Bij projecten binnen de gemeente Zaanstad, waarvan de gemeente Zaanstad ook initiatiefnemer is, wordt aanbevolen dat de gemeente het bureau dat natuuronderzoek verricht verplicht om de data digitaal aan te leveren in het format zoals beschreven in H 5.2. Indien gekozen wordt voor opslag bij de NDFF, dient het bureau er zorg voor te dragen dat zij de data aanleveren aan de NDFF.

\subsection{Opslag bij de Nationale Database Flora en Fauna (NDFF)}

De NDFF verzamelt, uniformeert en valideert natuurgegevens in Nederland. De gevalideerde gegevens brengen in beeld wat er bekend is over de verspreiding van diverse soortgroepen. In de databank zitten zowel records van losse waarnemingen van vrijwilligers (data uit telmee en waarneming. $\mathrm{nl}$ ) als data van derden (PGO's, TBO's etc.). In totaal zijn meer dan 100 databanken gebundeld. Voordeel van opslag van alle data m.b.t. de biodiversiteit van de gemeente is dat altijd actuele data beschikbaar zijn over de biodiversiteit van de gemeente. Koppeling van de databank van de gemeente dient te gebeuren door alle nieuwe data vanuit het meetnet van de gemeente periodiek te laden via het invoerportaal van de NDFF.

Het aantal licenties dat beschikbaar is bij de NDFF is gelimiteerd. Overwogen kan daarom worden om een koppeling tussen een 'stand alone'-database van de gemeente en de NDFF tot stand te brengen, door data periodiek te laden vanuit de NDFF in een ander 'dummy'-databestand. Voordeel hiervan is dat data breder beschikbaar komen voor medewerkers binnen de gemeente. 


\section{Analyse en interpretatie}

Analyse van data uit het meetnet kan plaatsvinden door de stadsecoloog of door uitbesteding. Voor het maken van verspreidingskaarten (bv. in GIS) zou de gemeente zelf aan de lat kunnen staan. Voordeel hiervan is dat beleid, groenbeheer en initiatiefnemers snel inzicht kunnen hebben in gebieden met biodiversiteitswaarde. Hotspots, kansenkaarten en zeldzame natuurwaarden kunnen hiermee ruimtelijk in kaart worden gebracht en een gedegen afweging mogelijk maken voor de gemeente. Op deze wijze kunnen verschillende beleidsvelden binnen de gemeente als het ware over de natuurwaardekaarten heen worden gelegd, bijvoorbeeld aanwezige en geplande woningbouw, industrie, infrastructuur, recreatie, landbouw en andere vormen van ruimtelijke ontwikkelingen. Met deze appelboormethode kan men vrij snel inzicht krijgen of geplande initiatieven en aanwezige (beschermde) natuurwaarden in het geding raken en/of waar ontwikkelingen vrij eenvoudig wel mogelijk zijn binnen de gemeente Zaanstad. Kortom, waar liggen natuurwaarden en natuurkansen en hoe verhouden deze zich tot andere ruimtelijke ontwikkelingen binnen de gemeente Zaanstad?

Voor het analyseren van trends in toe- of afname in areaal of adundantie is de analyse gecompliceerder. Statistische kennis is hiervoor onontbeerlijk, waarbij meerdere modellen en toetsen aan de orde zijn om bijvoorbeeld te corrigeren voor ontbrekende waardes. Landelijk worden data geanalyseerd met medewerking van het CBS. Tot voor kort gebeurde dit met TRIM (TRends and Indices for Monitoring data) waarin een aantal statistische modellen en -toetsen zijn gecombineerd. TRIM werd als freeware beschikbaar gesteld, maar wordt niet meer actief onderhouden (https://www.cbs.nl/nl-nl/maatschappij/natuur-en-milieu/indexen-en-trends--trim--). Als opvolger is RTRIM ontwikkeld, dat draait onder het statistische programma R. Het open-source karakter van R zal ook doorontwikkeling en toevoeging van nieuwe functionaliteit mogelijk maken, waardoor TRIM er naar verwachting weer vele jaren tegen kan. Het package is te vinden via CRAN (Comprehensive $R$ Archive Network).

Aanbevolen wordt om doelen te formuleren (bv. behoud, toename) voor de doelsoorten binnen de gemeente Zaanstad. Indien deze niet geformuleerd zijn in beleidsdocumenten lijkt het meten van de biodiversiteit minder zinvol. Voor het beleid van de gemeente is inzicht in trends versus doelstellingen en maatregelen een must. Na vaststelling van doelen is het bijvoorbeeld mogelijk om het (groen)beheer aan te passen om doelstellingen te halen. Daarnaast kan de ruimtelijke verspreiding inzicht geven over RO-zaken (waar wel, waar niet). 


\section{$7 \quad$ Communicatie en samenwerking}

\subsection{Welke partijen worden bediend?}

Het meetnet biodiversiteit Zaanstad is van belang voor:

- Initiatiefnemers/RO

- Burgers/bedrijven (industrie, agrarisch)

- Gemeente Zaanstad zelf

- O.a. Groenbeheerders, beleid, interne projectleiders. Denk ook aan de verschillende dorpskernen binnen Zaanstad.

- Terreinbeherende organisaties, zoals waterschap, Staatsbosbeheer, Landschap Noord-Holland en vereniging Natuurmonumenten.

\subsection{Communicatie, samenwerking en Citizen Science}

Voor het uitvoeren van een meetnet voor de biodiversiteit kan de gemeente gebruikmaken van professionals in betaalde projecten, maar zeker zo belangrijk is de uitvoering door vrijwilligers en nietprofessionals. Bosch et al. (2014) en Breman et al. (2017) voerden onderzoek uit naar de inzet van vrijwilligers en niet-professionals (Citizen Science) bij biodiversiteitsmeetnetten. Voor het opzetten en uitvoeren van een meetnet voor de biodiversiteit met Citizen Science, zijn drie factoren van belang:

1. De kwaliteit en betrouwbaarheid van data

2. Het verkrijgen van voldoende deelnemers

3. Het behouden van deelnemers

Om de kwaliteit van data die door vrijwilligers wordt verzameld te borgen, zijn een goede handleiding en begeleiding essentieel. Omdat deelnemers vaak op een verschillend kennisniveau zitten, is training essentieel. Cursusdagen, excursies, workshops, presentaties en feedback door soortexperts, de stadsecoloog en coördinatoren kunnen hieraan een bijdrage leveren. De stadsecoloog en coördinatoren van de diverse meetnetonderdelen van de gemeente Zaanstad spelen hier dan ook een belangrijke rol in.

Om voldoende deelnemers te verkrijgen, is het van belang dat zij het nut van het onderzoek inzien. Daarnaast is het verstandig om bij bestaande projecten aan te haken, zodat krachten worden gebundeld en meer mensen worden bereikt, zoals wij voorstellen, door zo veel mogelijk aan te sluiten bij bestaande meetnetten. De mogelijkheid bestaat ook dat individuele waarnemers al jarenlang actief zijn zonder concrete doelstelling anders dan het waarnemen. Het betrekken en aansturen van deze waarnemers zou een grote meerwaarde kunnen hebben voor de uitvoering van het meetnet binnen de gemeente.

Deelnemers aan de diverse onderdelen van dit meetnet voor de biodiversiteit van Zaandam zullen naar verwachting een bijdrage willen leveren als het ze duidelijk is wat er met de resultaten gebeurt en als de rol die ze vervullen interessant genoeg voor ze is. De communicatie naar de deelnemers dient dan ook op orde te zijn, zowel op individueel en groepsniveau als online. Tussentijdse resultaten kunnen via sociale media worden aangeboden, nieuwsberichten op een website etc., waardoor de betrokkenheid van deelnemers wordt bevorderd. Terugkoppeling door de stadsecoloog en coördinatoren m.b.t. foutief aangeleverde data (bv. determinatie of invoerfouten) draagt ook bij aan de betrokkenheid van de vrijwilligers. Nieuwe vaardigheden opdoen is een belangrijke factor voor mensen om blijvend onderdeel uit te maken van een monitoringsgroep. Ook communicatie naar bedrijven en burgers is van belang voor de betrokkenheid en werving van nieuwe deelnemers. Werving van nieuwe deelnemers kan ook worden bevorderd door het investeren in langjarige natuureducatie op scholen.

Burgers en bedrijven kunnen een belangrijke rol spelen bij het vergroten van de biodiversiteit in de gemeente. Om burgers en bedrijven expliciet te betrekken bij natuurwaarden, is communicatie van 
groot belang. Door publiekscampagnes, voorlichting via websites en bordjes, kranten, educatie, cursussen, groenmarkten etc. kan de bewustwording en de participatie van en door burgers en bedrijven worden vergroot. Aangezien biodiversiteit ook raakvlakken heeft met andere (beleids-) terreinen zoals klimaat en milieu kan hierbij soms 'meegekoppeld' worden. Om hier handen en voeten aan te geven, zou de gemeente kunnen overwegen om een plan te ontwikkelen waarin beschreven staat wat de concrete doelen zijn, wie de doelgroepen zijn, welke communicatiemiddelen worden ingezet, of er inhoudelijk verwante beleids- en communicatieprogramma's lopen etc. Voorlichting/het beschikbaar zijn van informatie is ook van belang voor initiatiefnemers binnen de gemeente, zodat zij kunnen anticiperen op de ontwikkeling van plannen voor ruimtelijke ontwikkelingen.

De communicatie naar diverse doelgroepen beslaat dan ook het hele scala aan beschikbare middelen, zoals lokale kranten, digitale media etc. Voor het op te starten meetnet voor de gemeente Zaanstad is een multidisciplinair team dan ook aan te raden. Hierin zitten naaste ecologisch inhoudelijk deskundigen ook ICT, educatie en communicatie-experts. Daarnaast kan mogelijk gebruikgemaakt worden van de inzet en expertise bij organisaties die binnen de gemeente actief zijn, zoals:

- Zaans Natuur en Milieu Overleg (ZNMO)

- Schooltuin

- Milieudefensie Zaanstreek

- Fietsersbond, KMZ

- Kontakt Milieubeheer Zaanstreek

- KMZ, Transition Town Zaanstreek en Kindertuinen

- ZEK

- Belangengroep Nauerna

- St. Kalverpolder

- OWB

- WBE Zaanstreek

- VBWZ

- Milieudefensie Zaanstreek

- Gierzwaluwenwerkgroep

- Staatsbosbeheer

- TTZ a/d Zaan en Eco a/d Zaan

- Vlinderwerkgroep

- 10 volkstuin complexen in Zaanstad

- Visvereniging, Hengelsport vereniging Zaanstreek HVZ

- Vogelwacht Zaanstreek

- Groen en bloei Zaanstad

Afstemming en samenwerking met derden die al monitoring uitvoeren, of willen gaan uitvoeren, is van groot belang vanwege de kosteneffectiviteit van de monitoring. Er lopen al monitoringsprogramma's binnen de gemeente, zoals de wettelijke verplichting tot monitoring van Natura 2000-gebieden en broedvogeltellingen. Controleer dus bij derden zoals, TBO's, PGO's, provincie wat er al wordt gedekt door lopende meetnetten. De in dit rapport voorgestelde methodes voor de diverse soortgroepen kunnen eventueel wijzigen indien lopende monitoring voldoet aan de vereisten van de gemeente. Samenwerking met TBO's is ook van belang omdat er mogelijk winst te halen valt voor de biodiversiteit. Veel soorten houden zich niet aan eigendomsgrenzen. Het beheer en beleid dat een eigenaar voert, kan dus impact hebben op (natuur)doelstellingen bij de buren. 


\section{Literatuur}

ANLb-team RAVON, 2016. Meetnet amfibieën Agrarisch Natuur- \& Landschapsbeheer. Handleiding beleidsmonitoring boomkikker, heikikker, kamsalamander, knoflookpad, poelkikker en rugstreeppad. Stichting RAVON, Nijmegen.

BIJ12, 2017. Kennisdocument Noordse woelmuis, versie 1.0, juli 2017.

Bosch, T., Fijen, T.P.M., de Laat, H.H.A., van Nieuwpoort, D., Reinders, M., Scheen, M., Scheepens, S. \& van Alebeek, F., 2014. Citizen science projecten effectief opzetten en uitvoeren voor ecologische studies in Nederland. ProPolis Rapport 1. ProPolis Ecologisch Adviesbureau, Wageningen \& onderzoeksinstituut Praktijkonderzoek Plant en Omgeving (PPO-AGV), Lelystad. 165 p.

Bouwman, J.H. \& V.J. Kalkman, 2004. Handleiding waarnemingen Nederlandse libellen. Nederlandse Vereniging voor Libellenstudie, De Vlinderstichting \& EIS-Nederland, Wageningen/Leiden

Breman, B.C., A.J.H. van Vliet \& L.A.E. Vullings, 2017. Citizen science voor natuur in Nederland; van onschatbare waarde en onderschat belang. Wageningen Environmental Research, rapport 2806.

Centraal Bureau voor de Statistiek (2000, herziene versie 2003). Handleiding Landelijk Meetnet Flora Milieu- en Natuurkwaliteit. CBS, Voorburg/Heerlen en Interprovinciale Werkgroep voor Inventarisatie en Monitoring van Natuur en Landschap (IAWM), subwerkgroep Flora en Vegetatie.

La Haye, M., V. Dijkstra \& N. Huizenga, 2017. NEM Verspreidingsonderzoek Bunzing Boommarter: inventariseren met cameravallen. Versie 23 februari 2017.

Provincie Noord-Holland Ontwerp-Natuurbeheerplan, 2018.

Provincie Noord-Holland. Natura 2000 beheerplan Ilperveld, Varkensland, Oostzanerveld en Twiske 2016-2022.

Provincie Noord-Holland. Natura 2000 beheerplan Polder Westzaan 2016-2022

Provincie Noord-Holland. Natura 2000 beheerplan Wormer- en Jisperveld \& Kalverpolder2016-2022.

Reemer, M., 2016. Bijen en zweefvliegen in het Leidse Singelpark: nulmeting 2015-2016. EIS2016-07, Leiden.

Rockström, J., W. Steffen, K. Noone, A. Persson, F. Stuart Chapin, E.F. Lambin, T.M. Lenton, M. Scheffer, C. Folke, H.J. Schellnhuber, B. Nykvist, C.A. de Wit, T. Hughes, S. van der Leeuw, H. Rodhe, S. Sörlin, P.K. Snyder, R. Costanza, U. Svedin, M. Falkenmark, L. Karlberg, R.W. Corell, V.J. Fabry, J. Hansen, B. Walker, D. Liverman, K. Richardson, P. Crutzen, J.A. Foley, 2009. A safe operating space for humanity. Nature. Vol. 461|24 September 2009.

Smit, G.F.J. \& A. Zuiderwijk, 2003. Handleiding voor het monitoren van reptielen in Nederland. CBS \& RAVON.

Sparrius, L., J. Loermans \& T. van de Vondervoort, 2015. Protocol voor het inventariseren van muurplanten. Floron-rapport 59.

Spikmans, F., J. Kranenbarg, L. Soldaat, M. de Zeeuw \& A. van Strien, 2011. Handleiding NEMMeetnet Beek- en Poldervissen. Stichting RAVON, Nijmegen.

van Manen, W. \& de Jong, A., 2016. Handleiding Punt Transect Tellingen project (PTT). Sovon Vogelonderzoek Nederland, Nijmegen.

Van Swaay, C.A.M., Termaat, T. \& C.L. Plate, 2011. Handleiding Landelijke Meetnetten Vlinders en Libellen. Rapport VS2011.001, De Vlinderstichting, Wageningen \& Centraal Bureau voor de Statistiek, Den Haag.

Van Turnhout, C. \& Van Diek, H., 2007. Handleiding MUS (Meetnet Urbane Soorten). SOVON Vogelonderzoek Nederland, Beek-Ubbergen.

Veer, R. van 't, T. Kisjes \& N. Sminia, 2012. Natuuratlas Zaanstad. Stichting uitgeverij Noord-Holland. Vergeer, J.W., Van Dijk, A.J., Boele, A., van Bruggen, J. \& Hustings, F., 2016. Handleiding Sovon broedvogelonderzoek: Broedvogel Monitoring Project en Kolonievogels. Sovon Vogelonderzoek Nederland, Nijmegen. 


\section{Bijlage 1 Huizen, erven, overig: stedelijk en landelijke (lint)bebouwing inclusief tuinen, erven, bestrating, (kade)muren}

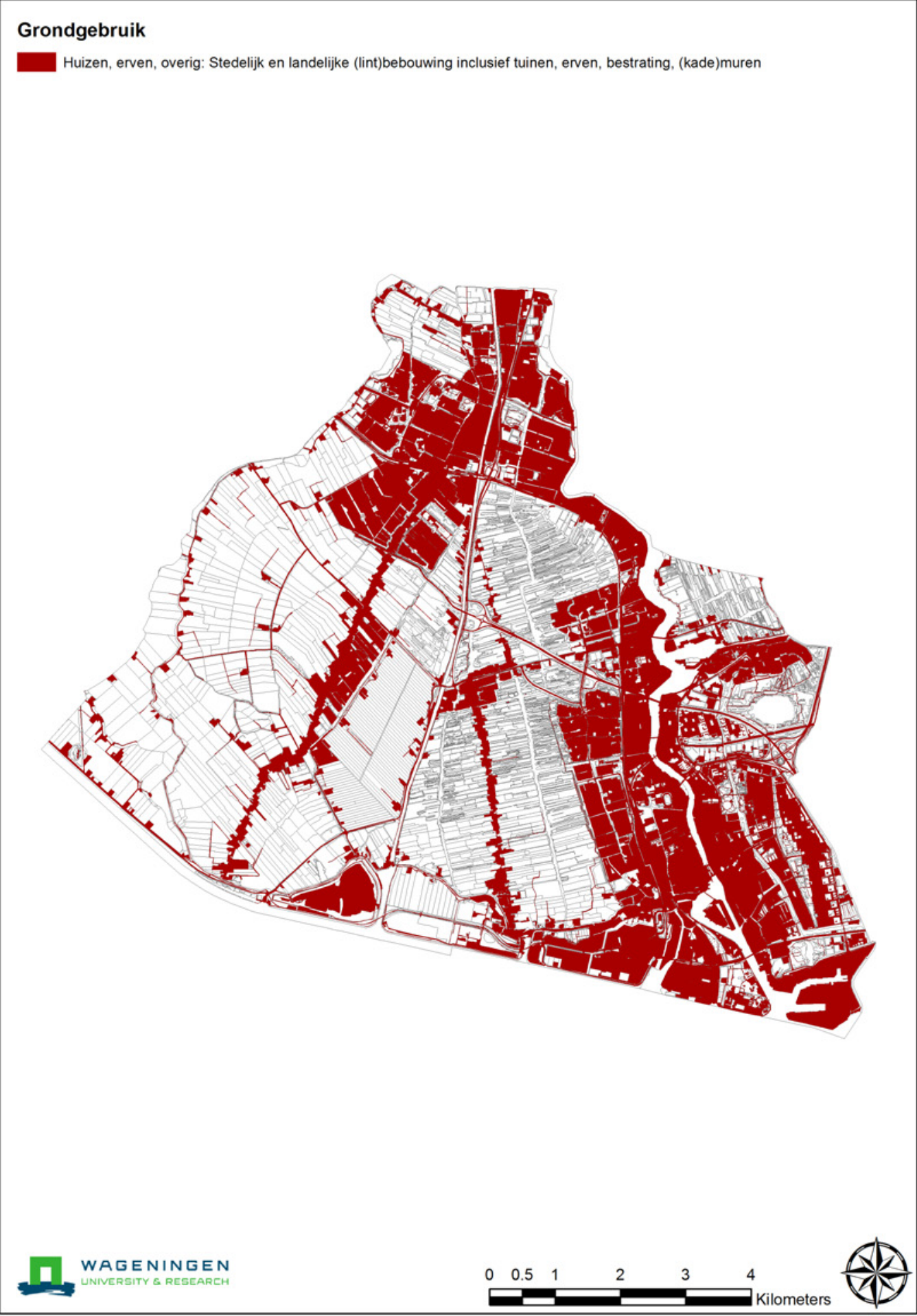




\section{Bijlage 2 Broekbossen: elzen-, berken- en wilgenbroekbossen}

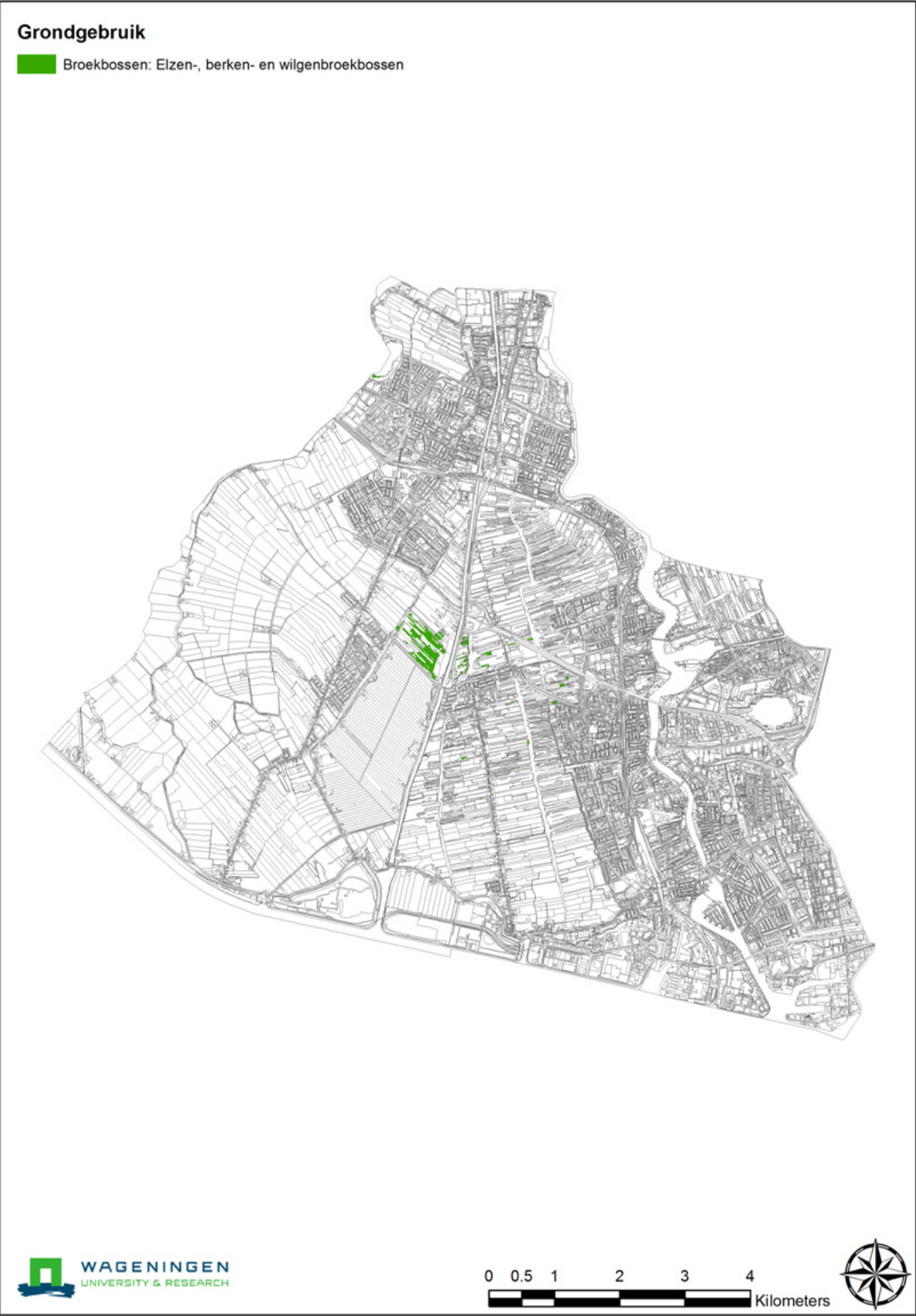




\section{Bijlage 3 Stadsparken: stadsparken en begraafplaatsen}

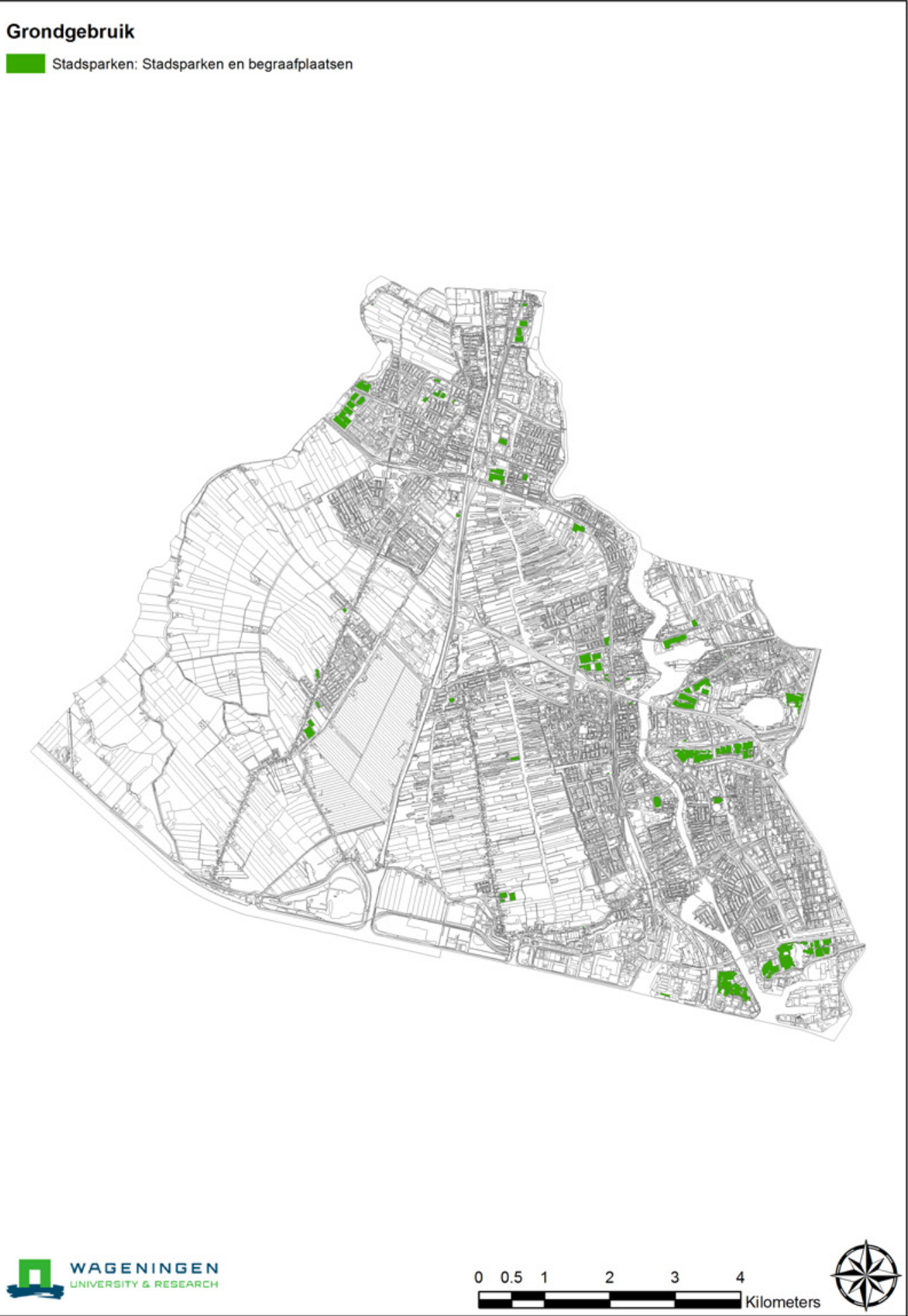




\section{Bijlage 4 Loofbos \& struweel: loofbos, houtwallen, bomenrijen, struweel inclusief mantel/zoom}

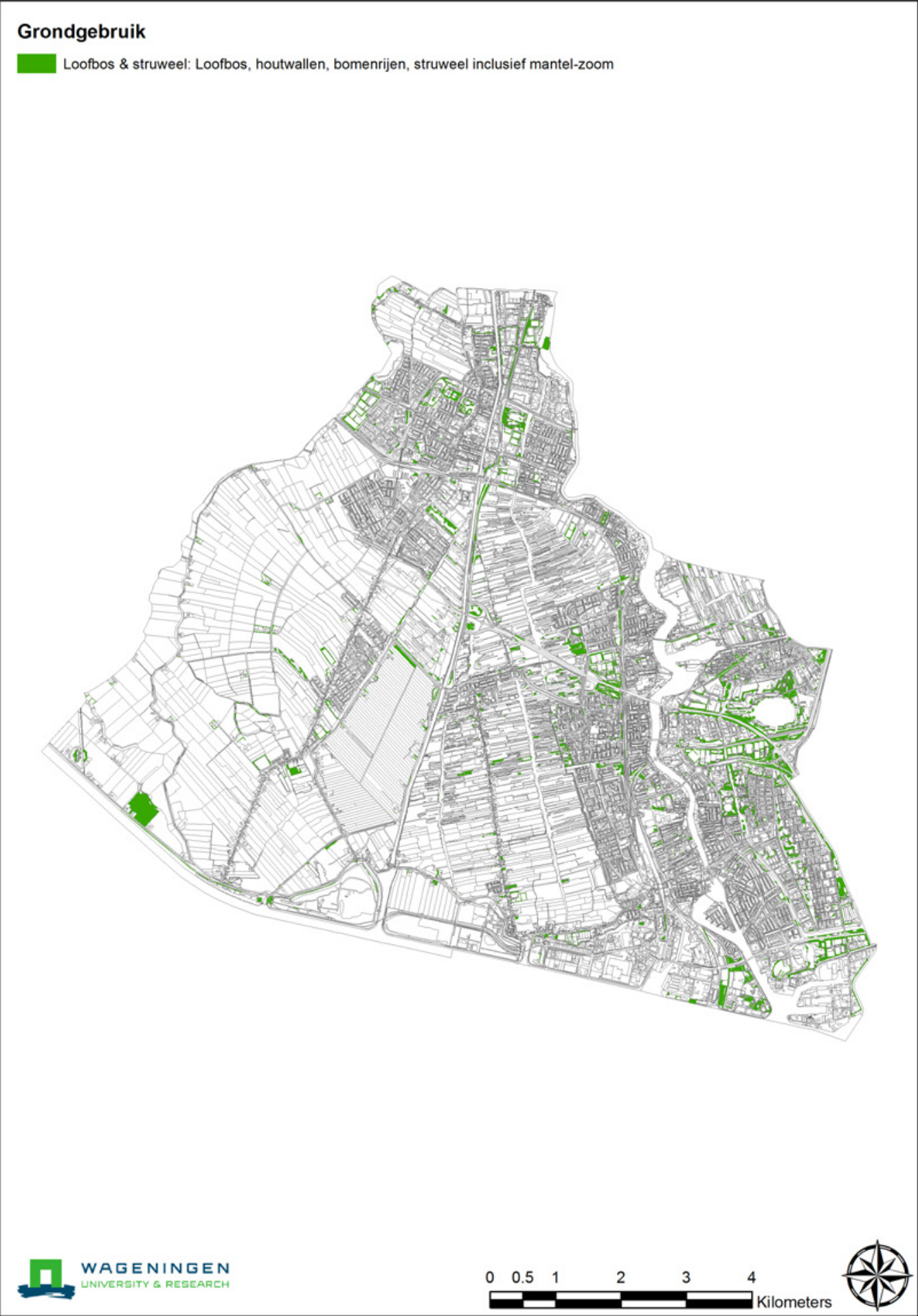




\section{Bijlage 5 Veenheide: vochtige laagveenheide}

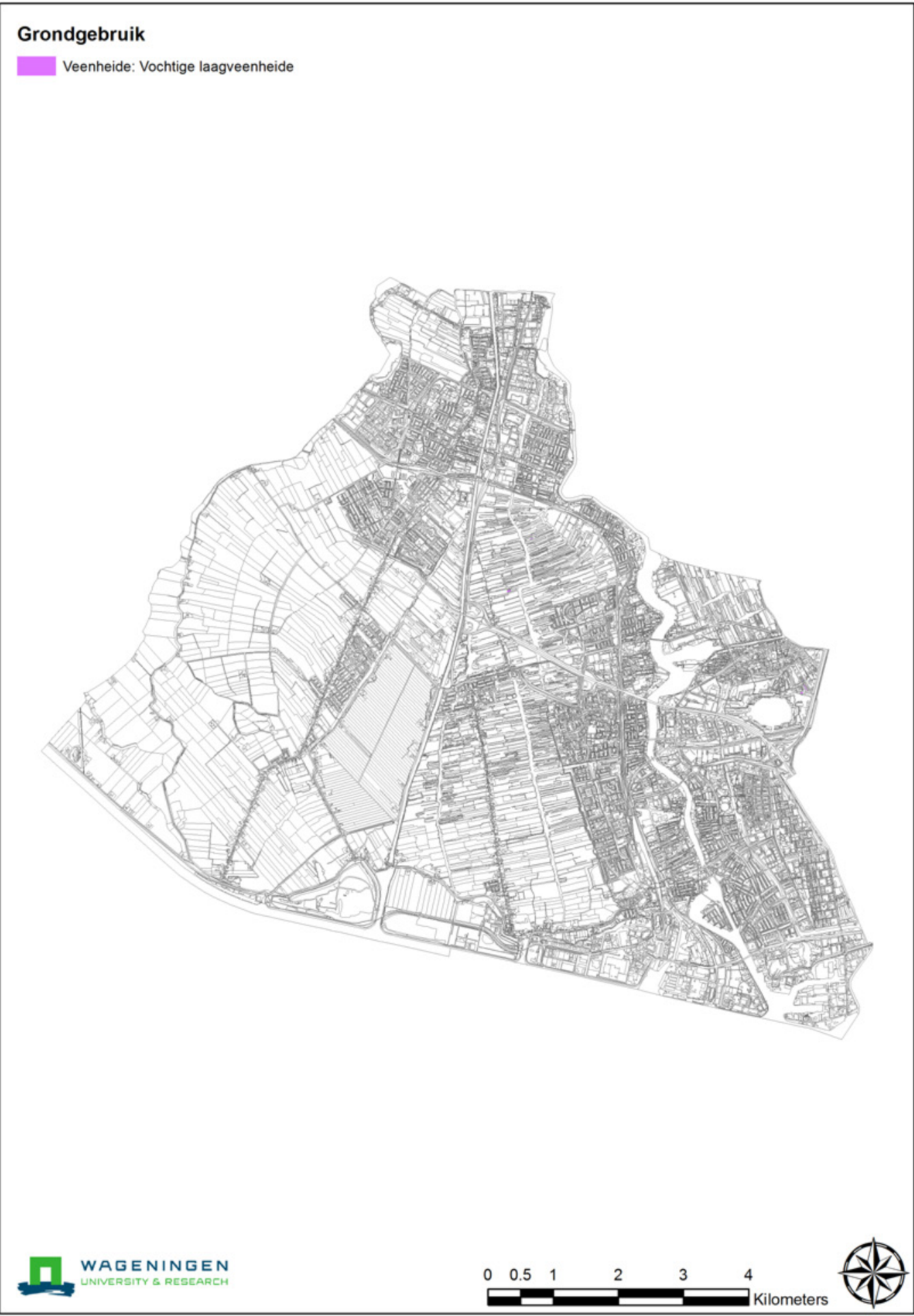




\section{Bijlage 6 Rietland: alle typen rietland, inclusief jonge verlandingsstadia, exclusief verzuurde veenmos- rietland en droog rietland}

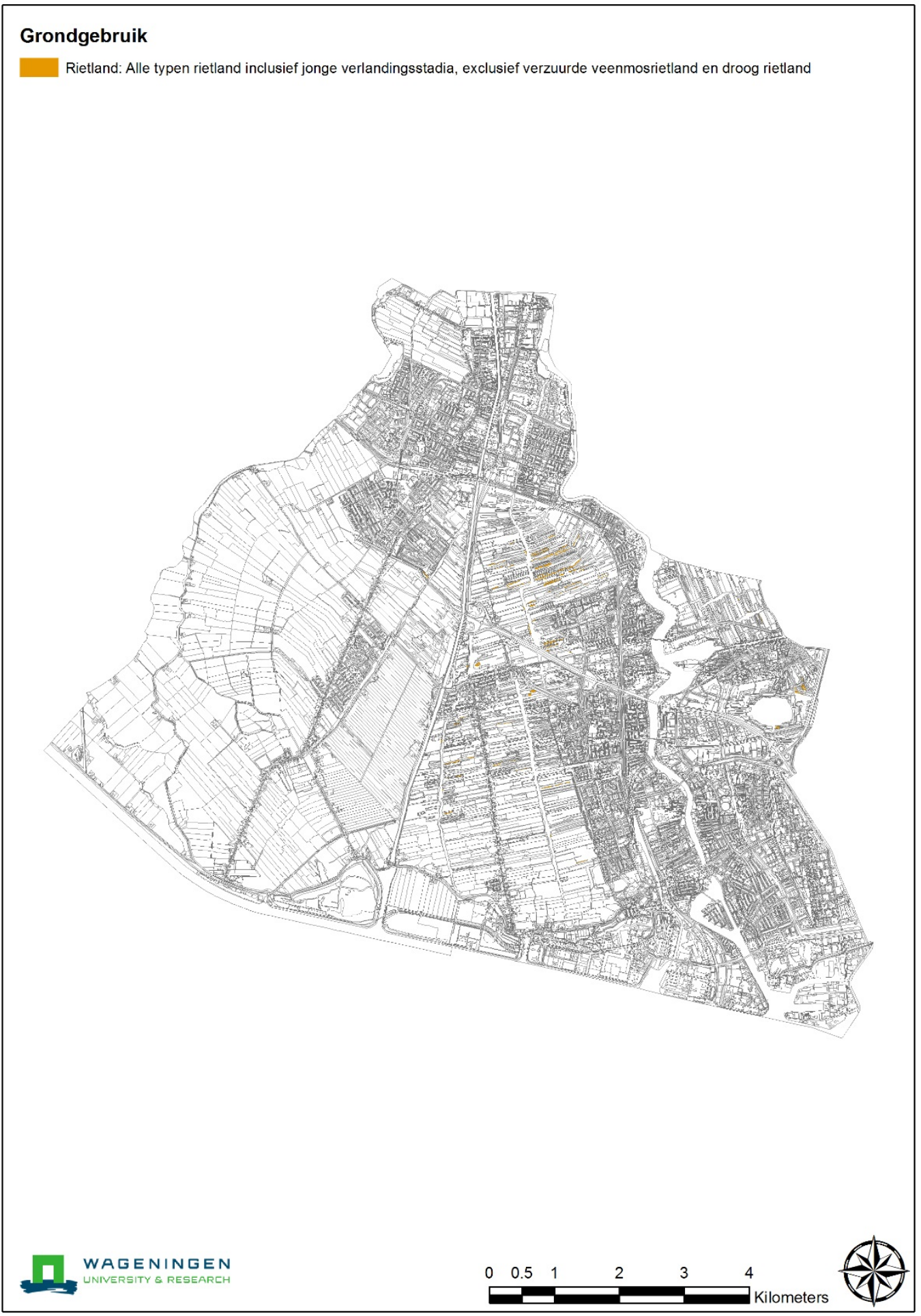




\section{Bijlage 7 Veenmosrietland en veenhooiland: veenmosrietland en haarmosrietlanden, veenhooiland}

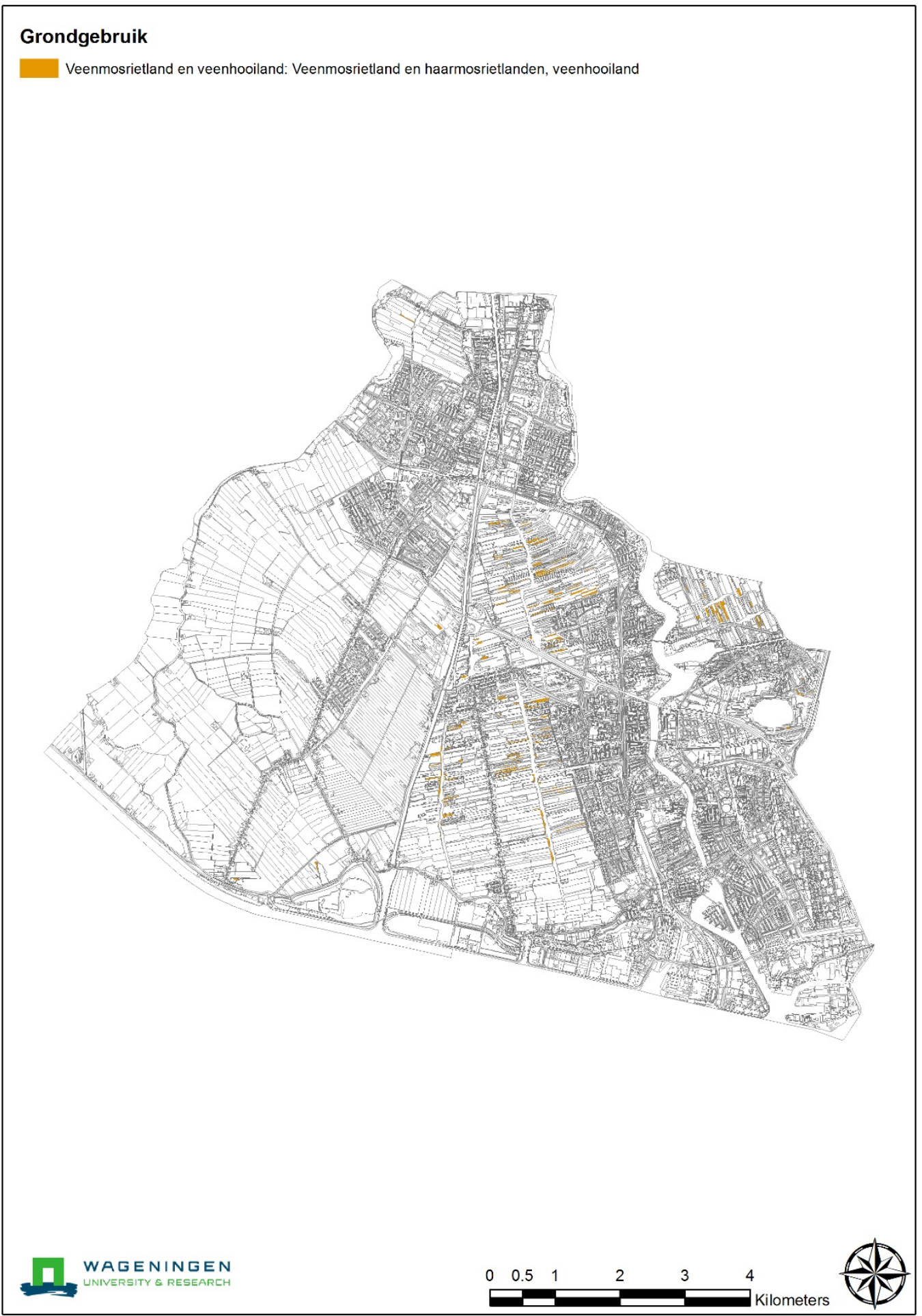




\section{Bijlage 8 Moeras en vochtige ruigte: niet tot weinig gemaaide moerasvegetatie en verruigde moerasvegetatie}

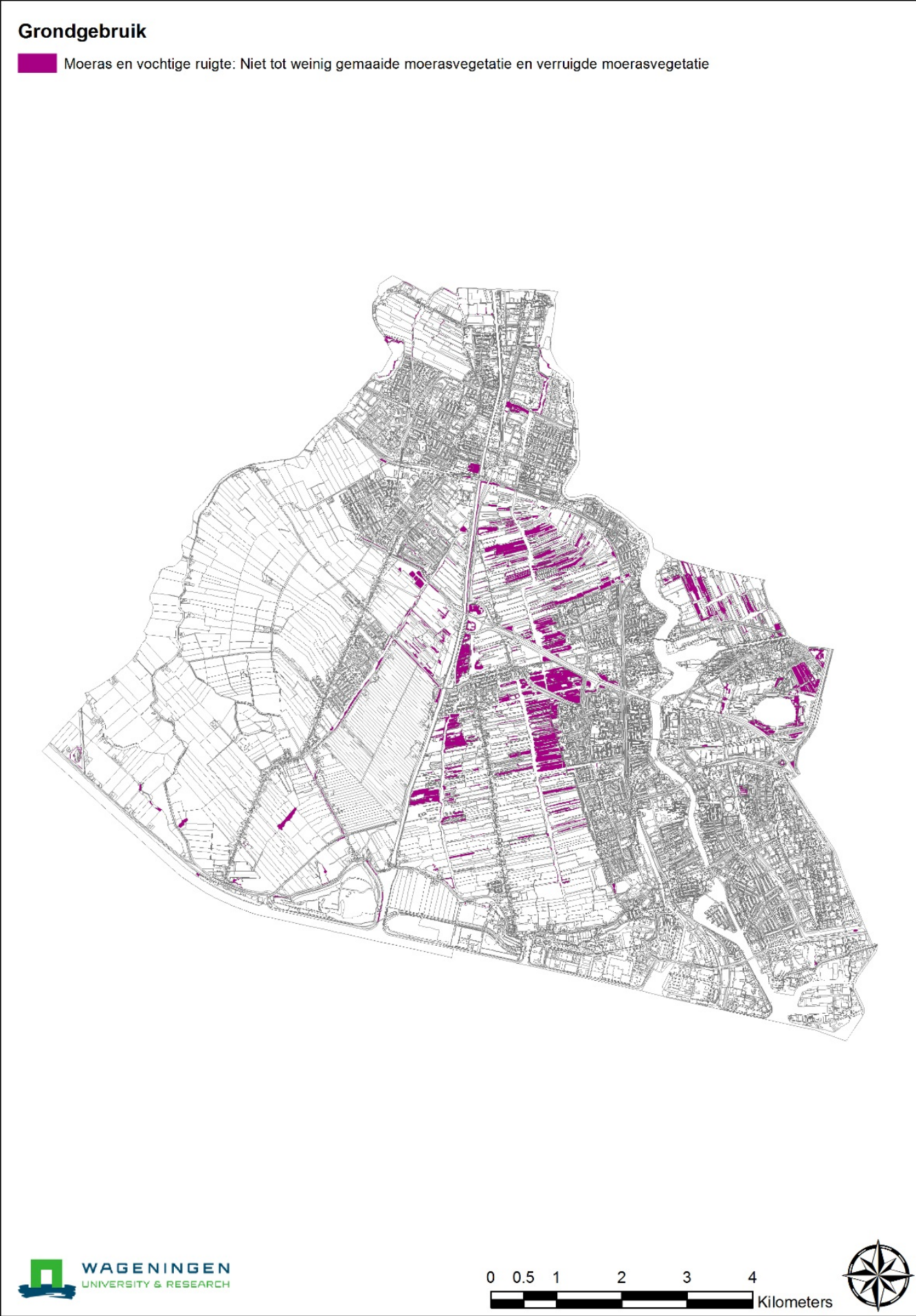




\section{Bijlage 9 Droge rietlanden en ruigte: onbeheerde, droge, verruigde terreinen}

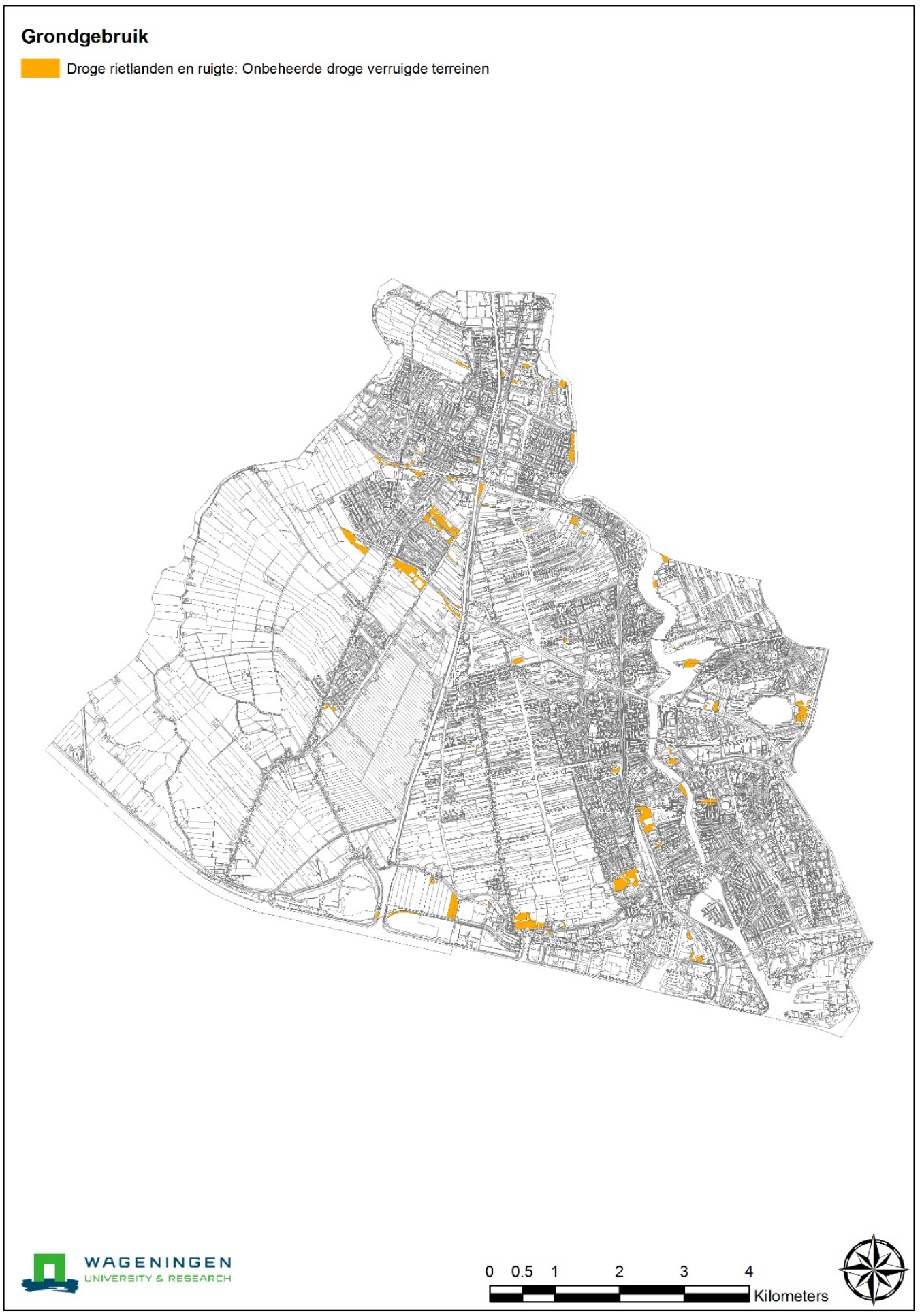




\section{Bijlage 10 Kruidenrijk grasland: extensief beheerd grasland en schraalland}

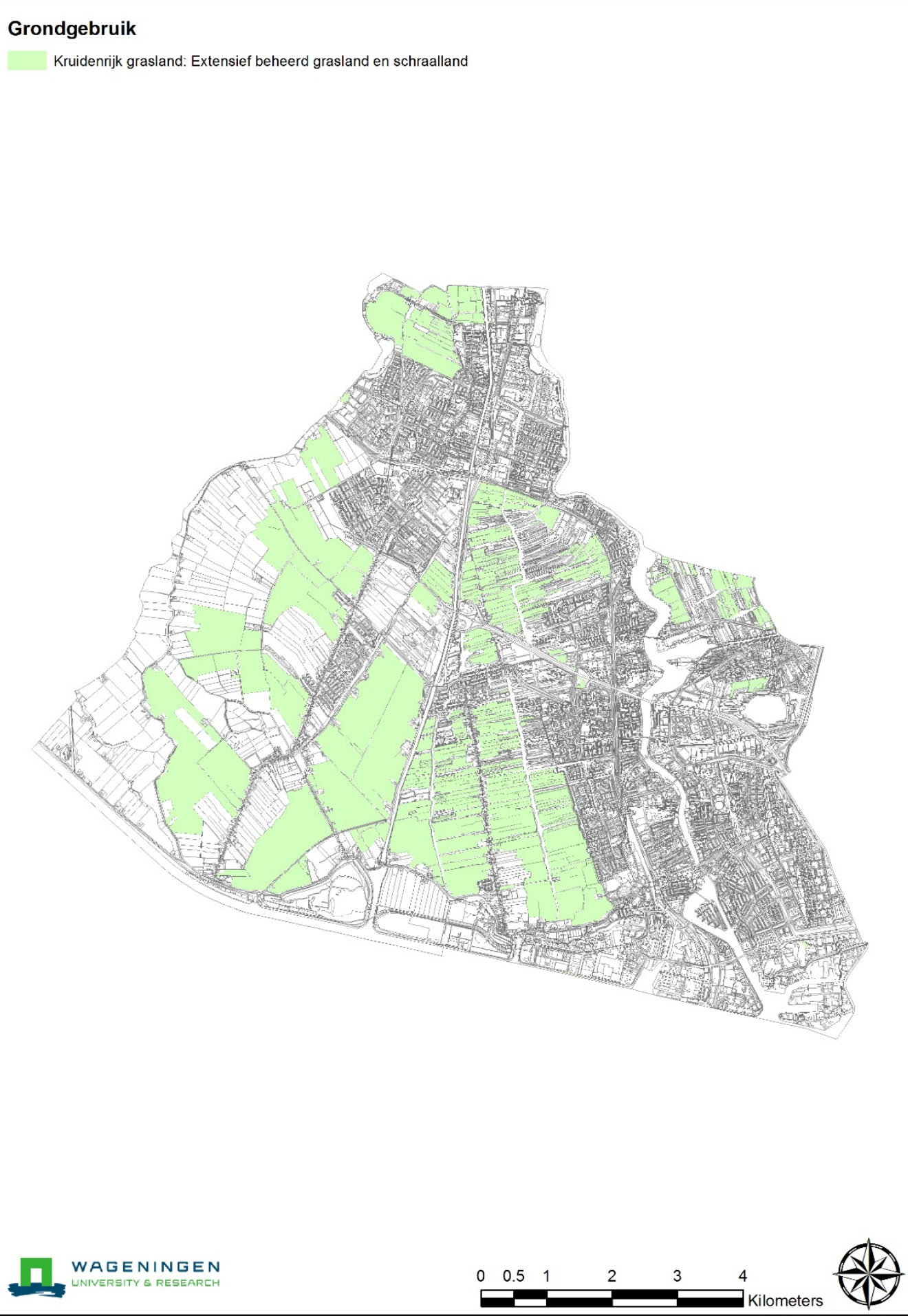




\section{Bijlage 11 Plasdras: in het voorjaar nat tot zeer nat grasland}

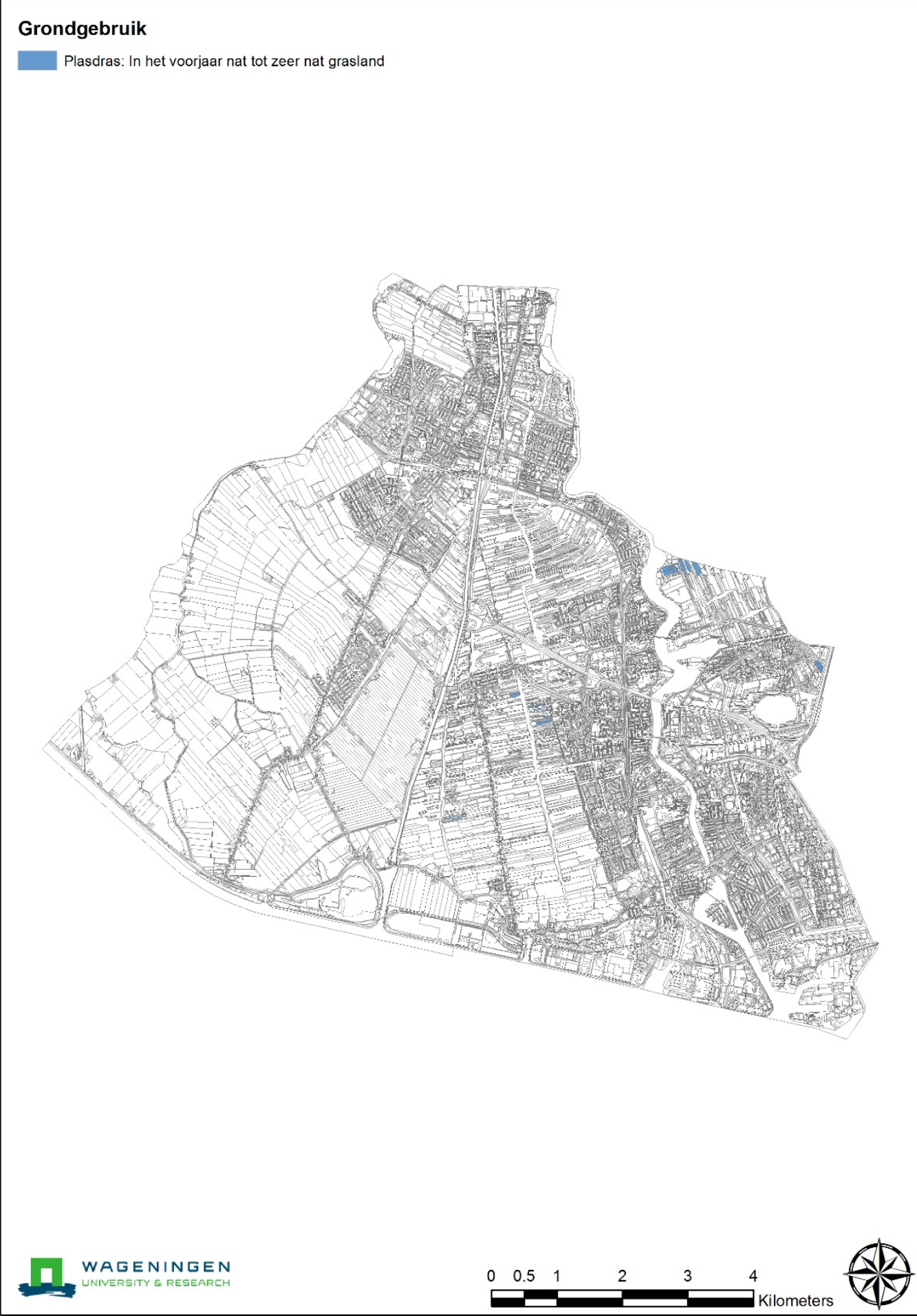




\section{Bijlage 12 Wegberm: alle wegbermen, zowel schraal als rijk, intensief en extensief beheerd}

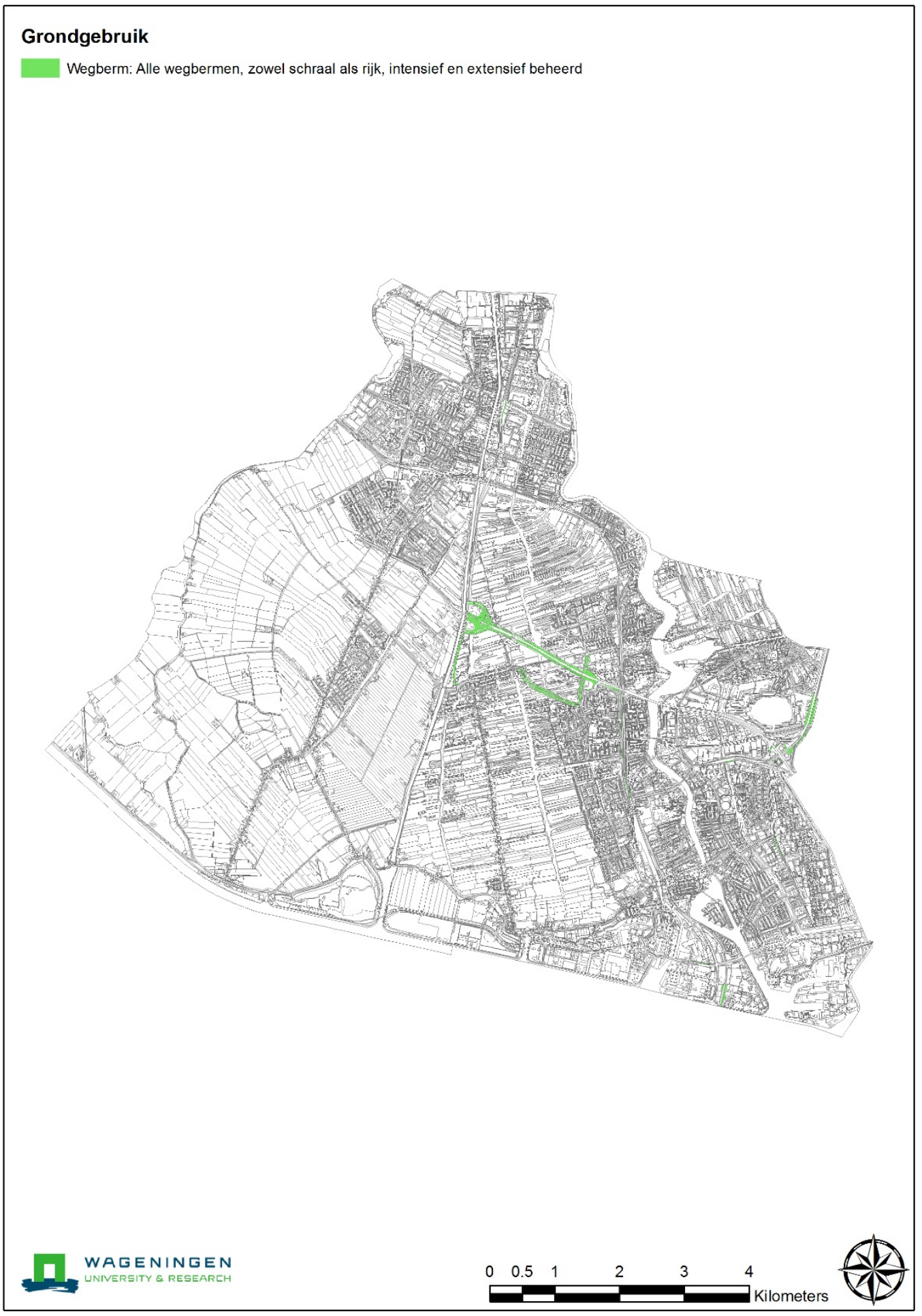




\section{Bijlage 13 Agrarisch grasland: intensief beheerd grasland met een hogere mestgift en een laag waterpeil}

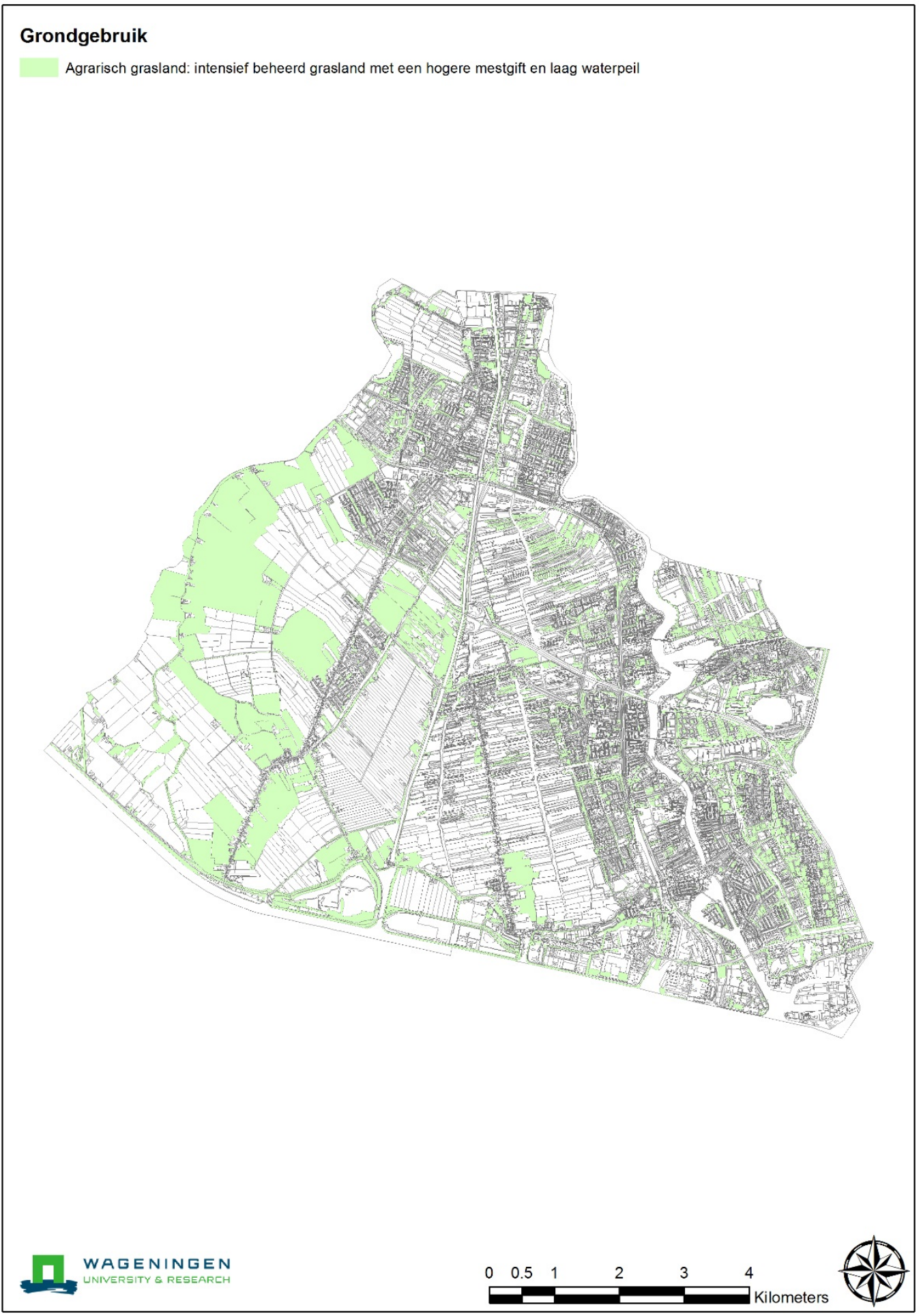




\section{Bijlage 14 Plantsoengras: intensief beheerde plantsoenen (gemeentelijk groen)}

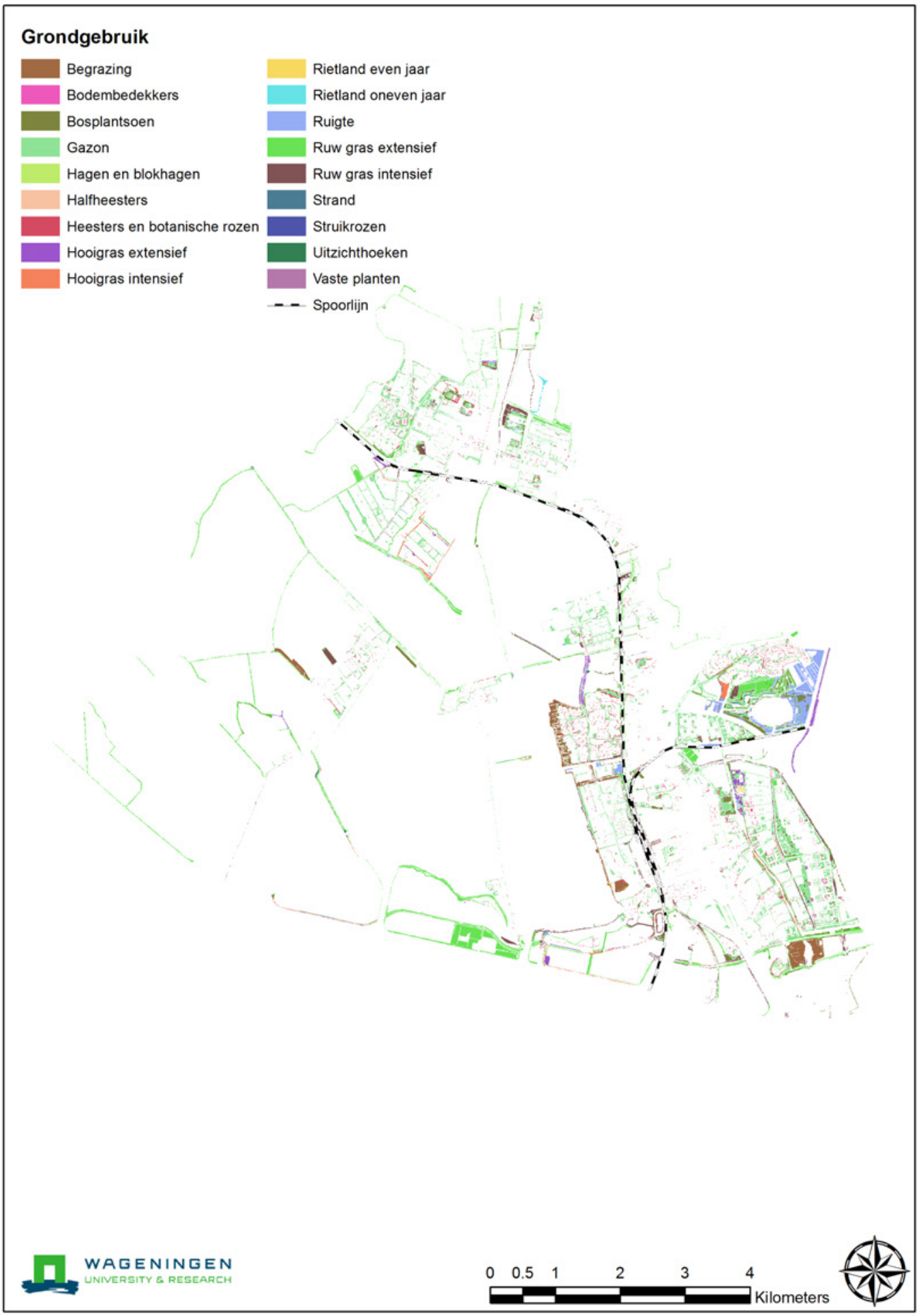




\section{Bijlage 15 Tijdelijke natuur Droog: ruderale en opgespoten terreinen met droge bodem}

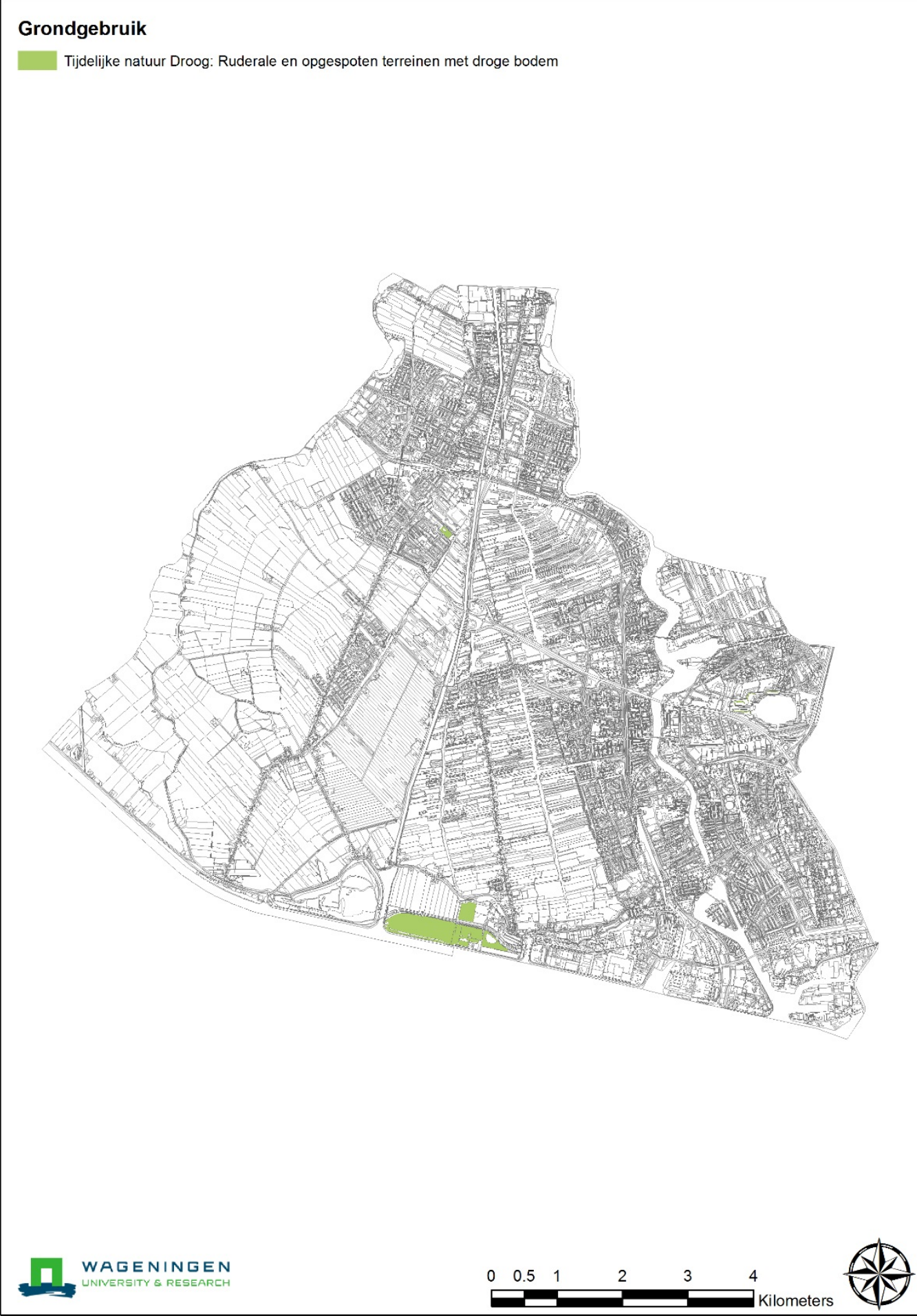




\section{Bijlage 16 Tijdelijke natuur Nat: ruderale en opgespoten terreinen met vochtige tot natte bodem}

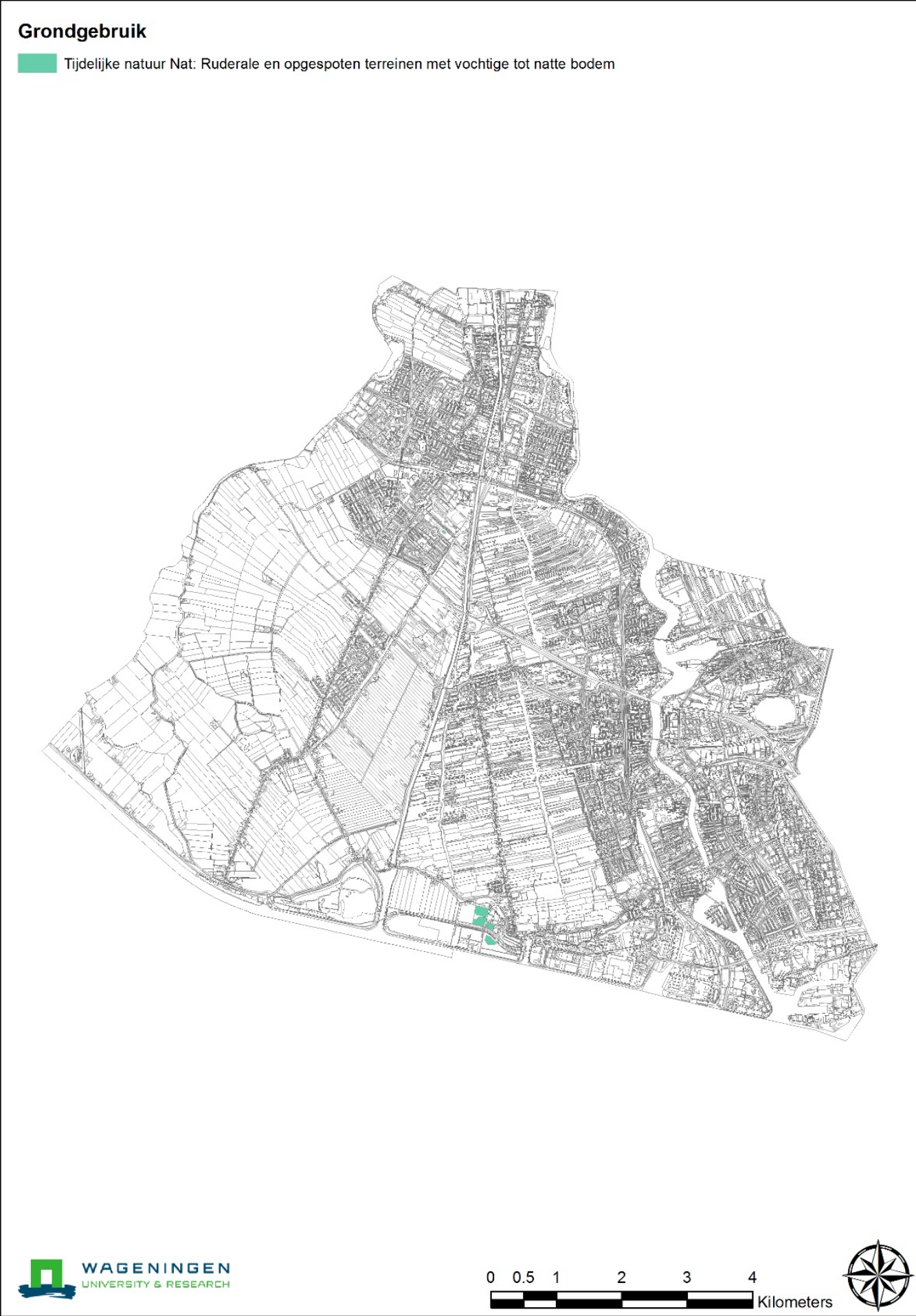




\section{Bijlage 17 Volkstuinen: volkstuinen, inclusief opgaande erfbeplanting}

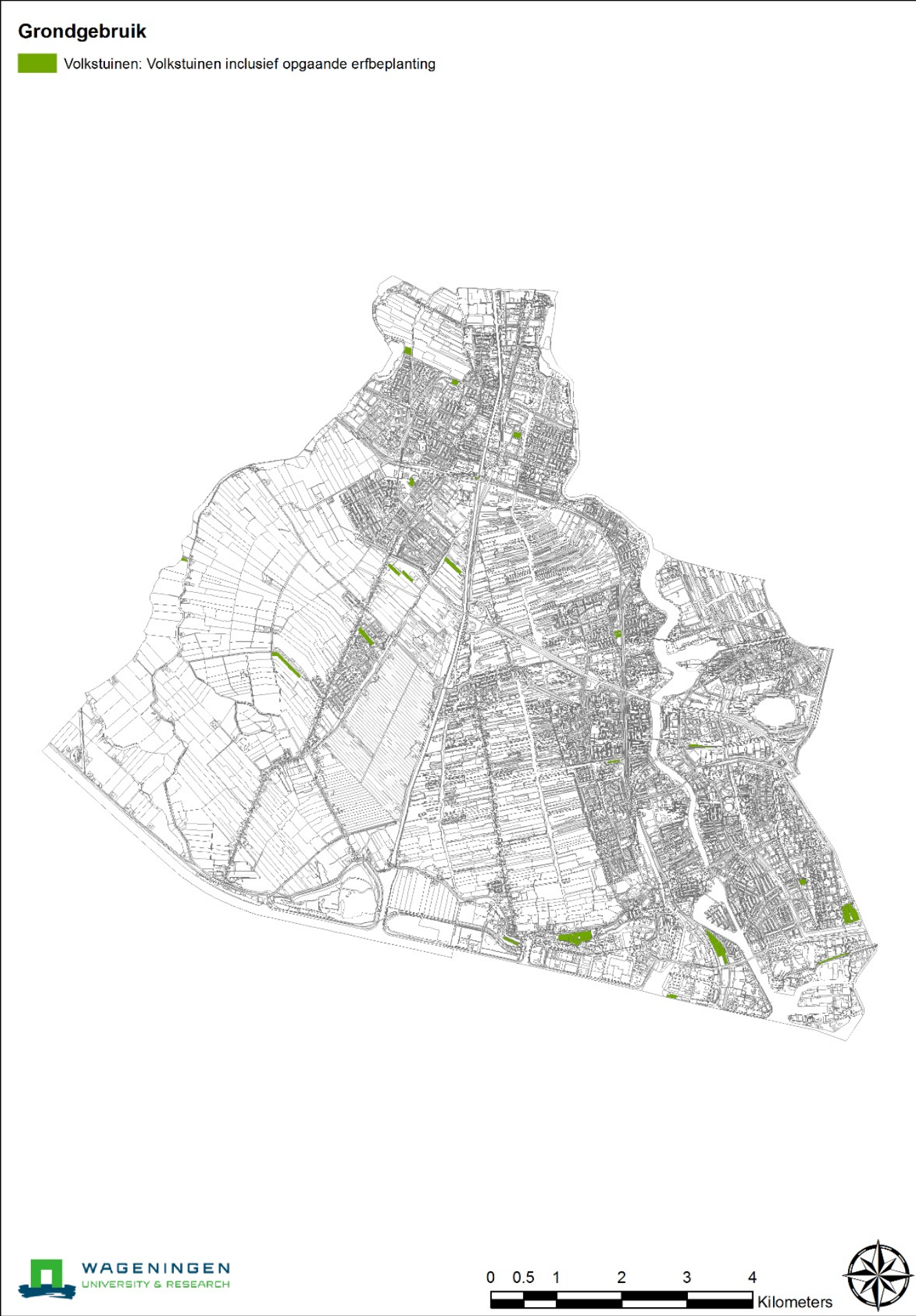




\section{Bijlage 18 Bouwland: akkers}

\section{Grondgebruik}

Bouwland: Akkers

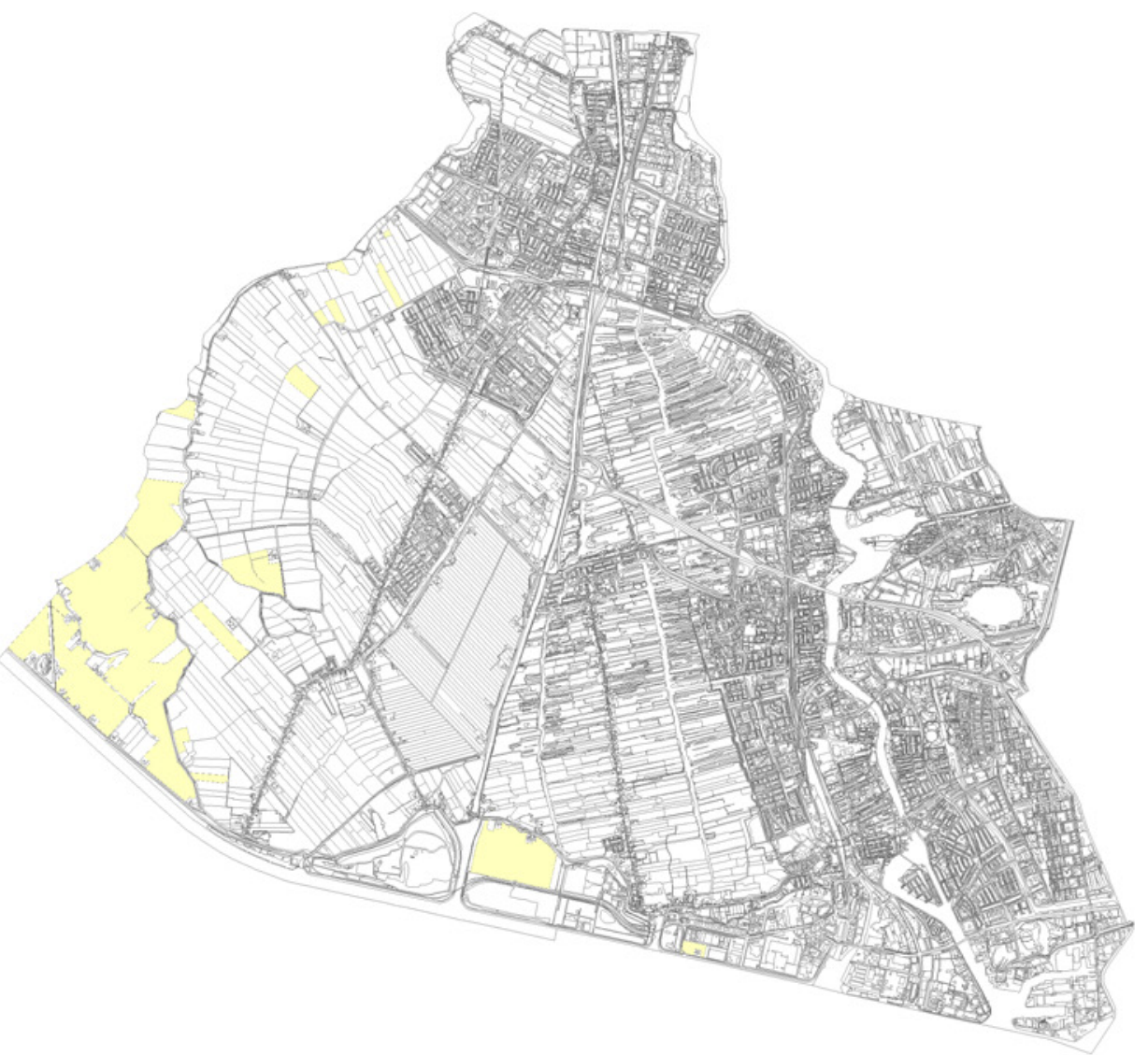




\section{Bijlage 19 Brakwater: brakwater inclusief oeverzone/zoom}

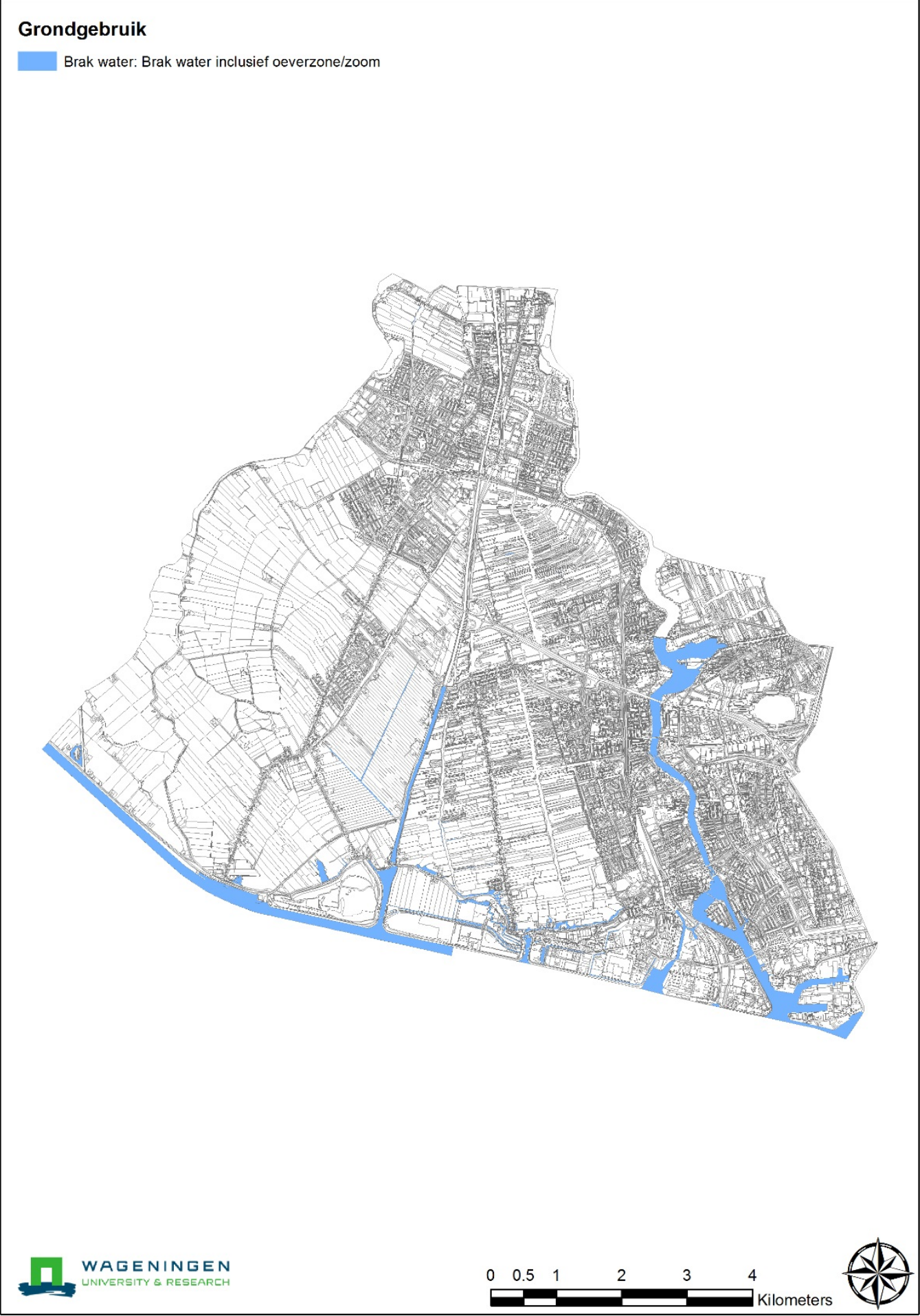




\section{Bijlage 20 Zoetwater: zoetwater, inclusief oeverzone/zoom}

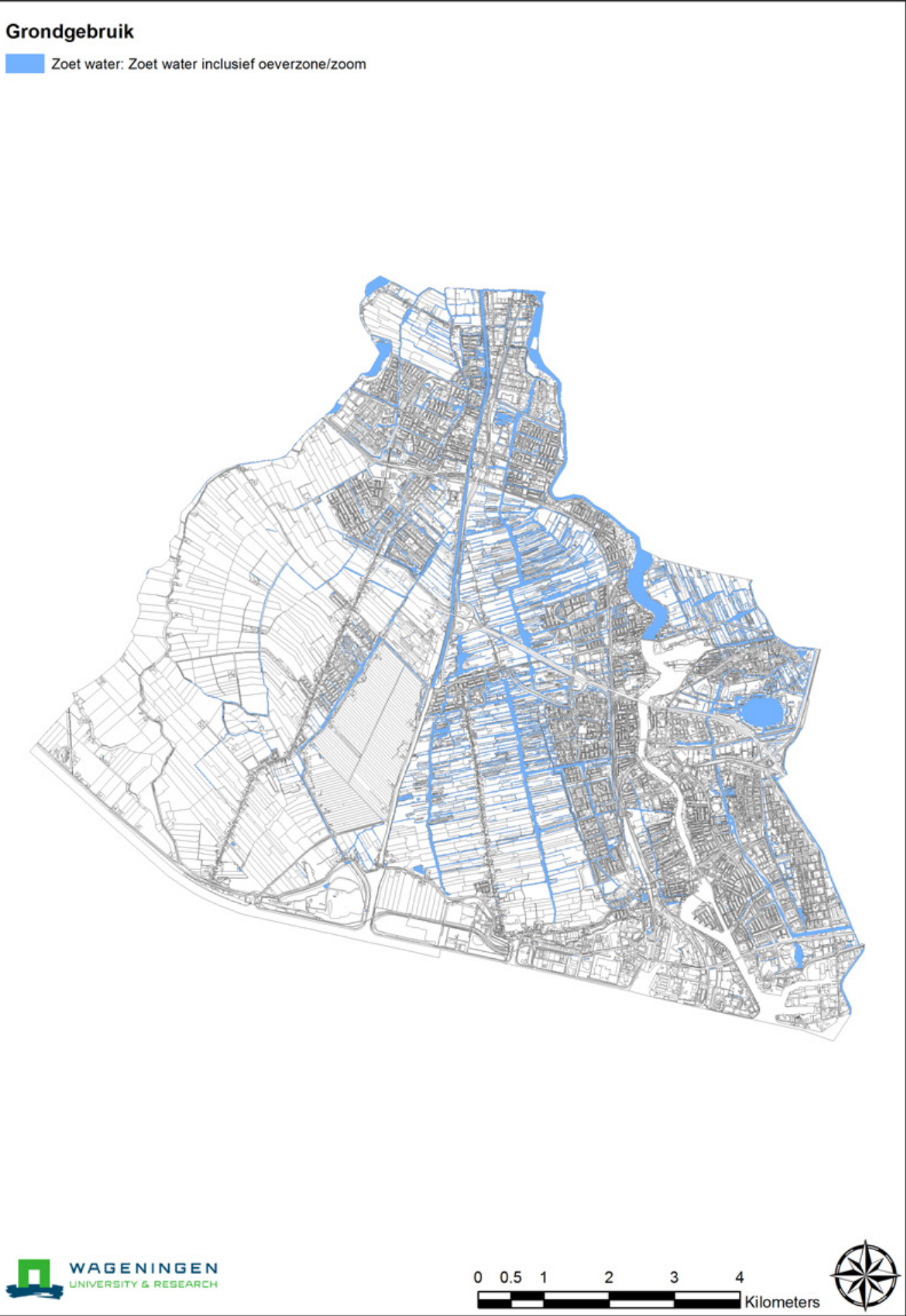


Wageningen Environmental Research Postbus 47

6700 AA Wageningen

T 0317480700

www.wur.nl/environmental-research

Wageningen Environmental Research Rapport 2866

ISSN 1566-7197
De missie van Wageningen University \& Research is 'To explore the potential of nature to improve the quality of life'. Binnen Wageningen University \& Research bundelen Wageningen University en gespecialiseerde onderzoeksinstituten van Stichting Wageningen Research hun krachten om bij te dragen aan de oplossing van belangrijke vragen in het domein van gezonde voeding en leefomgeving. Met ongeveer 30 vestigingen, 5.000 medewerkers en 10.000 studenten behoort Wageningen University \& Research wereldwijd tot de aansprekende kennisinstellingen binnen haar domein. De integrale benadering van de vraagstukken en de samenwerking tussen verschillende disciplines vormen het hart van de unieke Wageningen aanpak. 



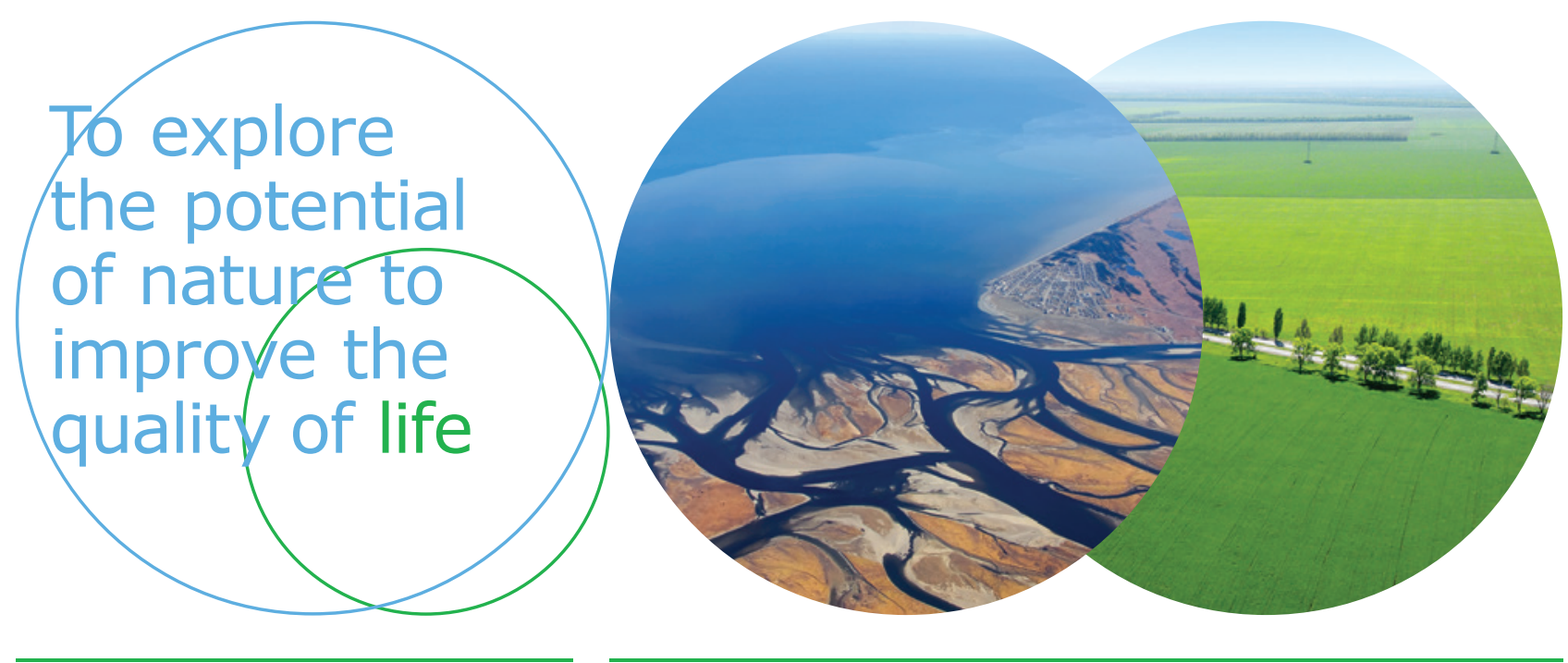

Wageningen Environmental Research Postbus 47

$6700 \mathrm{AB}$ Wageningen

T 317480700

www.wur.nl/environmental-research

Rapport 2866

ISSN 1566-7197
De missie van Wageningen University \& Research is 'To explore the potential of nature to improve the quality of life'. Binnen Wageningen University \& Research bundelen Wageningen University en gespecialiseerde onderzoeksinstituten van Stichting Wageningen Research hun krachten om bij te dragen aan de oplossing van belangrijke vragen in het domein van gezonde voeding en leefomgeving. Met ongeveer 30 vestigingen, 5.000 medewerkers en 10.000 studenten behoort Wageningen University \& Research wereldwijd tot de aansprekende kennisinstellingen binnen haar domein. De integrale benadering van de vraagstukken en de samenwerking tussen verschillende disciplines vormen het hart van de unieke Wageningen aanpak. 